\title{
Avaliação dos efeitos do extrato etanólico, resíduo butanólico e resíduo aquoso de Pfaffia paniculata sobre o crescimento do tumor de Ehrlich em suas formas ascítica e sólida
}

Dissertação apresentada ao Programa de Pósgraduação em Patologia Experimental e Comparada da Faculdade de Medicina Veterinária e Zootecnia da Universidade de São Paulo, para a obtenção do título de mestre em Ciências

Departamento:

Patologia

Área de concentração:

Patologia Experimental e Comparada

Orientador:

Prof $^{a}$. Dr ${ }^{a}$. Maria L. Z. Dagli 
Autorizo a reprodução parcial ou total desta obra, para fins acadêmicos, desde que citada a fonte.

DADOS INTERNACIONAIS DE CATALOGAÇÃO-NA-PUBLICAÇÃO

(Biblioteca da Faculdade de Medicina Veterinária e Zootecnia da Universidade de São Pauło)

T. 1426 Matsuzaki, Patricia

FMVZ

Avaliação dos efeitos do extrato etanólico, residuo butanólico e residuo aquoso de Pfaffia paniculata sobre o crescimento do tumor de Ehrlich em suas formas ascítica e sólida / Patrícia Matsuzaki. São Paulo : P. Matsuzaki, 2004.

$116 \mathrm{f.}:$ il.

Dissertação (mestrado) - Universidade de São Paulo. Faculdade de Medicina Veterinária e Zootecnia. Departamento de Patologia, 2004.

Programa de Pós-graduação: Patologia Experimental e Comparada.

Área de concentração: Patologia Experimental e Comparada.

Orientador: Profa. Dra. Maria Lucia Zaidan Dagli.

1. Neoplasias. 2. Plantas. 3. Tumor de Ehrlich. 4. Pfaffia paniculata. 5. Cultura de células. I. Titulo. 


\section{UNIVERSIDADE DE SÃO PAULO \\ Faculdade de Medicina Veterinária e Zootecnia \\ Cidade Universitária “Armando de Salles Oliveira”}

\section{Comissão Bioética \\ CERTIFICADO}

Certificamos que o Projeto intitulado "Efeito dos extratos etanólico, butanólico e aquoso de Pfaffia paniculata sobre o crescimento do tumor de Ehrlich em suas formas ascítica e sólida", Protocolo $n^{\circ} 157 / 2002$, sob a responsabilidade da Prof ${ }^{a}$ Dr $^{a}$ Maria Lucia Zaidan Dagli, está de acordo com os princípios éticos de experimentação animal da Comissão de Bioética da Faculdade de Medicina Veterinária e Zootecnia da Universidade de São Paulo e foi aprovado pela referida Comissão, em sessão de 05/06/2002.

(We certify that the Research "Effect of ethanolic, butanolic and aqueous extract of Pfaffia paniculata on the development of the ascitic and solid Ehrlich tumor" protocol number 157/2002, under the responsability of Prof ${ }^{a}$ Dr $^{\mathrm{a}}$ Maria Lucia Zaidan Dagli, agree with Ethical Principles in Animal Research adopted by Bioethic Commission of the Faculty of Veterinary Medicine and Zootechny of University of São Paulo and was approved in 06/05/2002 meeting.

São Paulo, 05 de junho de 2002

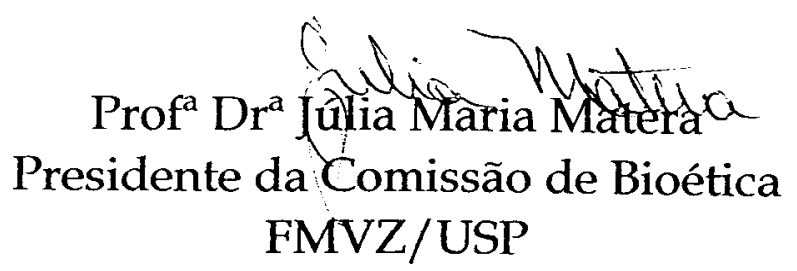




\section{FOLHA DE AVALIAÇÃO}

Nome do autor: MATSUZAKI, Patrícia

Título: Avaliação dos efeitos do extrato etanólico, resíduo butanólico e resíduo aquoso de Pfaffia paniculata sobre o crescimento do tumor de Ehrlich em suas formas ascítica e sólida

Dissertação apresentada ao Programa de Pósgraduação em Patologia Experimental e Comparada da Faculdade de Medicina Veterinária e Zootecnia da Universidade de São Paulo, para a obtenção do título de mestre em Ciências

Data:

\section{Banca Examinadora}

Prof.Dr.

Assinatura

Instituição

Julgamento

Prof.Dr.

Assinatura

Instituição

Julgamento

Prof.Dr.

Assinatura

Instituição

Julgamento 
À "Malu", orientadora e amiga, por ser um exemplo a ser seguido, e por toda a confiança transmitida que nos levam a continuar caminhando... 
Aos meus pais, por tudo que sou. 


\section{Ao Rodolfo e Lisa, (in memorian) \\ Lisa e Clarinha, \\ que sempre torceram pelo meu sucesso.}

Ao Shigueaki,

por tornar os meus dias

mais belos. 


\section{AGRADECIMENTOS}

Ao Prof. Dr. Idércio L. Sinhorini, do Departamento de Patologia da FMVZ-USP, pelo seu carinho a todos e pelas agradáveis conversas que influenciaram tanto a minha formação profissional quanto pessoal.

Ao Prof. Dr. José Luis Guerra, do Departamento de Patologia da FMVZ-USP, pelo apoio durante toda a realização deste projeto.

Ao Prof. Dr. Paulo C. Maiorka, do Departamento de Patologia da FMVZ-USP, pelas valiosas críticas e sugestões.

Ao Prof. Dr. João P. Neto, do Departamento de Patologia da FMVZ-USP, pelo apoio na realização deste projeto.

Ao Prof. Dr. Roger Chammas, da Faculdade de Medicina-USP, pela atenção que sempre nos dispensou.

À Prof ${ }^{a}$. Dr ${ }^{a}$. Mitsue Haraguchi, do Instituto Biológico, pela obtenção dos extratos da raiz e pela gentileza de sempre.

Ao Prof. Dr. Gokithi Akisue, pelo fornecimento da raiz utilizada neste projeto.

A Prof ${ }^{a}$. Dr ${ }^{a}$. Silvana L. Górniak, do Departamento de Patologia da FMVZ-USP, pelo auxílio durante a realização deste projeto.

Ao Prof. Jorge C. Flório, do Departamento de Patologia da FMVZ-USP, pelo auxílio na realização das análises estatísticas.

Ao Prof. Dr. José E. Belizário, do Instituto de Ciências Biomédicas, pela atenção dispensada.

À Sílvia, da Secretaria de pós-graduação do Departamento de Patologia da FMVZ-USP, pela extrema atenciosidade e gentileza por todos que a procuram. 
À Sr. Elza M. R. B. Faquim, pela extrema gentileza no auxílio da elaboração desta dissertação.

Às minhas queridas amigas Silvinha, Márcia, Kátia, Mônica e Evelise, pela inestimável ajuda na realização deste projeto, e principalmente pela amizade.

Aos colegas de laboratório José Luis, Tereza, Heidge e Lucas, pela ajuda e sugestões na realização deste trabalho.

Às minhas grandes amigas Daniella, Sandra e Esther, que sempre torceram pelo meu sucesso.

À minha amiga Adriana, do Laboratório de Biologia Molecular Aplicada e Sorologia, que sempre torceu pelo meu sucesso e por estes anos de convivência.

À Andréia, do Laboratório de Oncologia Experimental da Faculdade de MedicinaUSP, pelo auxílio na análise do ciclo celular por citometria de fluxo.

Ás amigas Kátia Kimura e Stéfanie, pela amizade e pela alegria que transmitem a todos.

Á colega Cristina de Oliveira M. S. Gomes, pela atenciosidade e auxílio na realização deste trabalho.

Aos colegas Dario, Elaine, Fabiana, Daniel e Ricardo, pelo agradável convívio.

Aos colegas Luciana, Ana, Daniel e Emerson, pelo auxílio na interpretação das lâminas histológicas.

À Cláudia C. Mori, pela paciência e atenção sempre presentes.

À Elena, Ana, Margareth, Maria, Dirce, Solange e Mara, funcionárias da biblioteca desta faculdade, pela competência e atenção que sempre dispensaram às nossas solicitações.

Ao Thomas e Luiz, da Faculdade de Ciências Farmacêuticas, pela liofilização do material utilizado neste projeto. 
Às colegas de laboratório Renata, Carolina e Kátia, pela agradável convivência.

Á Cynthia, Viviane, Sheila e Ivone, pela atenção dedicada ao laboratório e pela extrema gentileza.

Aos colegas do biotério Rosiris, Idalina e Herculano, pelo bom-humor e pelo auxílio no manejo dos animais.

Á Dona Rô, Cláudia, Marguiti, Cristina, Nelsinho, Raymundo, Shirley e Edson, pelo companheirismo.

À Sílvia, da Secretaria de pós-graduação do Departamento de Patologia da FMVZUSP, pela extrema atenciosidade e gentileza por todos que a procuram.

À Priscila, Magali e Ricardo, funcionários do Laboratório de Farmacologia do Departamento de Patologia da FMVZ-USP, pela atenciosa ajuda.

Ao Cláudio e Luciano, funcionários do Laboratório de Histologia do Departamento de Patologia da FMVZ-USP, pela confecção das lâminas histológicas.

À Fundação de Apoio e Amparo à Pesquisa do Estado de São Paulo, pela bolsa concedida (processo 02/05082-0). 


\section{RESUMO}

MATSUZAKI, P. Avaliação dos efeitos do extrato etanólico, resíduo butanólico e resíduo aquoso de Pfaffia paniculata sobre o crescimento do tumor de Ehrlich em suas formas ascítica e sólida. [Evaluation of effects of the ethanolic extract, butanolic residue and aqueous residue of Pfaffia paniculata on the development of Ehrlich tumour in its ascitic and solid forms]. 2004. 116 f. Dissertação (Mestrado em Ciências) - Faculdade de Medicina Veterinária e Zootecnia, Universidade de São Paulo, São Paulo, 2004.

As raízes de Pfaffia paniculata têm sido popularmente utilizadas com vários propósitos, assim como adjuvante na terapia contra o câncer. Recentemente demonstramos que as raízes pulverizadas de Pfaffia paniculata causam uma atenuação do crescimento do tumor de Ehrlich em sua forma ascítica. Os objetivos do presente estudo foram caracterizar os efeitos do extrato etanólico, resíduos aquoso ou butanólico de Pfaffia paniculata sobre o desenvolvimento do tumor de Ehrlich, assim como investigar seus possíveis mecanismos. Em um primeiro experimento, foi demonstrado que camundongos machos Swiss, portadores do tumor de Ehrlich ascítico, tratados com resíduo aquoso ou butanólico, apresentaram uma maior sobrevida em relação aos animais controle. Nos experimentos com o tumor na forma sólida ou ascítica, os animais receberam, diariamente, o resíduo butanólico por 16 dias (experimento com o tumor sólido) ou 15 dias (experimento com o tumor ascítico). No $8^{\circ}$ dia de tratamento, foram inoculados com $2,5 \times 10^{6}$ células tumorais, no coxim plantar esquerdo, ou com $5,0 \times 10^{6}$ células tumorais, intraperitonealmente. O tumor ascítico foi avaliado, 7 dias após a inoculação do tumor, pela quantificação do volume de fluído ascítico, concentração de células tumorais e número total de células tumorais. O tumor sólido foi avaliado pela mensuração diária das patas e pela morfometria da área de necrose em meio à massa tumoral em cortes corados por HE, e proliferação celular, por imunoistoquímica, 8 dias após a inoculação do tumor. 
Nesses experimentos, nenhum destes parâmetros avaliados apresentaram alterações nos camundongos tratados com este resíduo. A fim de se avaliar a toxicidade do resíduo butanólico, os animais foram tratados com este resíduo por 14 dias. Os animais tratados com este resíduo apresentaram uma discreta diminuição de ganho de peso. Não houve evidências de toxicidade hepática e renal, pela mensuração das atividades de enzimas indicativas de necrose e pelo exame histopatológico de figado e rim, onde não se observou necrose. Em outro experimento, alguns parâmetros da atividade macrofágica, 24 após a inoculação do tumor, foram avaliados, por citometria de fluxo. Os animais receberam o resíduo butanólico por 7 dias, e foram inoculados com $5 \times 10^{6}$ células tumorais, intraperitonealmente. O burst oxidativo ativado por Staphylococcus aureus foi menor em animais tratados com o resíduo, porém não foram observadas diferenças ma fagocitose e burst oxidativo espontâneo ou ativado por PMA. Por fim, estudos in vitro foram realizados. Os efeitos deste resíduo sobre a viabilidade, medido pelo ensaio do MTT, e sobre o ciclo celular, utilizando citometria de fluxo, de células do tumor de Ehrlich foram avaliados. As maiores concentrações do resíduo levaram a uma diminuição da viabilidade e um aumento de morte celular. Assim, o tratamento com este resíduo, in vivo, causou uma atenuação do desenvolvimento tumoral, provavelmente devido a uma diminuição na formação do fluído ascítico ou a morte celular. Os efeitos deste resíduo foram mais pronunciados em cultura celular.

Palavras-chave: Neoplasias. Plantas. Tumor de Ehrlich. Pfaffia paniculata. Cultura de células. 


\section{ABSTRACT}

MATSUZAKI, P. Evaluation of effects of the ethanolic extract, butanolic residue and aqueous residue of Pfaffia paniculata on the development of Ehrlich tumour in its ascitic and solid forms. [Avaliação dos efeitos do estrato etanólico, resíduo butanólico e resíduo aquoso de Pfaffia paniculata sobre o crescimento do tumor de Ehrlich em suas formas ascítica e sólida]. 2004. 116 f. Dissertação (Mestrado em Ciências) - Faculdade de Medicina Veterinária e Zootecnia, Universidade de São Paulo, São Paulo, 2004.

The roots of Pfaffia paniculata have been popularly used for various purposes, as well as an adjuvant for cancer therapy. Recently we have shown that the powdered roots of Pfaffia paniculata promote an attenuation of the Ehrlich tumor growth in its ascitic form. The aims of the present study were to characterize the effects of the ethanolic extract, aqueous or butanolic residues of Pfaffia paniculata on Ehrlich tumor development in mice, as well as investigate its possible mechanisms. In a first experiment, it was shown that aqueous or butanolic residues-treated Swiss mice bearing Ehrlich ascites tumor presented a higher survival time than control animal. In the experiments with the tumor in its solid or ascitic forms, the animals were given, daily, the butanolic residue for 16 days (experiment with solid tumor) or 15 days (experiment with ascitic tumor). On the $8^{\circ}$ day of treatment, they were inoculated with $2,5 \times 10^{6}$ tumor cells, on the left footpad, or with $5 \times 10^{6}$ tumor cells, intraperitoneally. The ascitic tumor was evaluated, 7 days after the inoculation of the tumor, by the quantification of the volume of the ascitic fluid, concentration of tumor cells and total number of tumor cells. The solid tumor was evaluated by the daily measurement of the footpads and morphometry of the necrosis within the tumor area on HE stained slices, and cell proliferation by immunohistochemistry, 8 days after the inoculation of the tumor. In these experiments, none of these parameters showed any alterations in 
mice treated with the residue. In order to evaluate the toxicity of butanolic residue, the animals were treated with this residue $(200 \mathrm{mg} / \mathrm{Kg})$ for 14 days. The animals treated with the residue showed a discrete decrease on weight gain. There were no evidences of hepatic and renal toxicity, by measurement of enzymes activities of necrosis, and also lack of necrosis by histopathological analysis of liver and kidney. In another experiment, some parameters of macrofagic activity, 24 hours after the inoculation of tumor, were evalueted, by flow citometry. The animals received the butanolic residue for 7 days and then were inoculated with $5 \times 10^{6}$ tumor cells, intraperitoneally. The oxidative burst activated by Staphylococcus aureus was reduced on animals treated with the residue, but no differences on fagocytosis and spontaneous or oxidative burst esimulated by PMA were found. Finally, in vitro studies were performed. The effects of this residue on the cell viability, measured by the MTT assay, and on the cell cycle, by flow cytometry, in Ehrlich tumor cells were evaluated. The highest concentrations of the residue caused a decrease of the cell viability and an increase of death cell. Thus, the treatment with this residue, in vivo, caused an attenuation of the tumor development, likely due to a decrease in the ascitic fluid formation or cell death. The effects of this residue on cell death were more pronounced in cultured cells. These results point to a novel agent for the cancer therapy, but further studies must be performed to elucidate the mechanisms responsible for these effects.

Key-words: Neoplasia. Plants. Ehrlich tumor. Pfaffia paniculata. Cell culture. 


\section{SUMÁRIO}

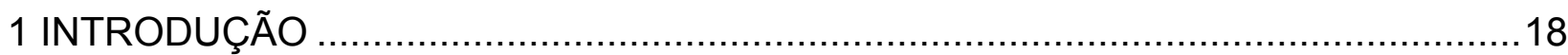

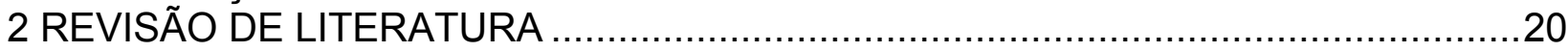

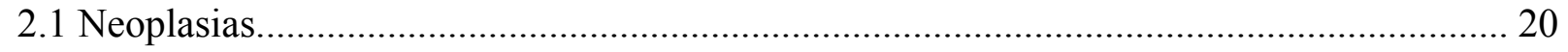

2.2 Tumor de Ehrlich................................................................................................ 22

2.3 Tumor de Ehrlich e imunologia tumoral ..................................................................... 25

2.4 Modelos experimentais in vitro ………………………………………………….... 27

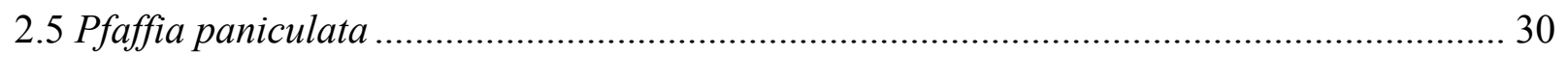

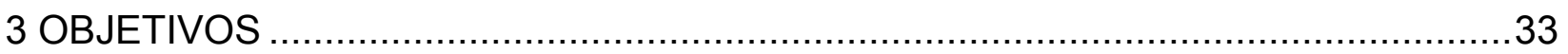

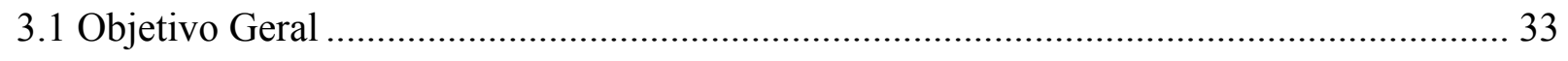

3.2 Objetivos Específicos ......................................................................................... 33

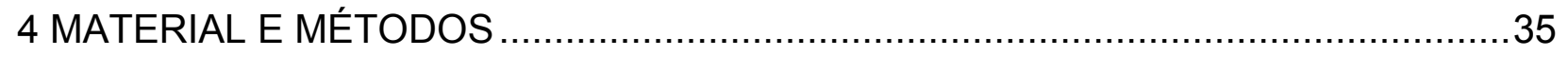

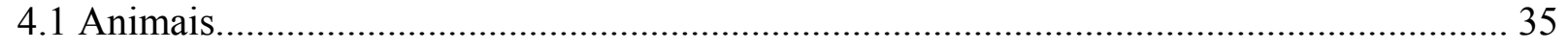

4.2 Raízes de Pfaffia paniculata....................................................................................... 35

4.3 Obtenção do extrato e resíduos de Pfaffia paniculata ........................................................ 36

4.4 Reagentes e soluções ............................................................................................. 36

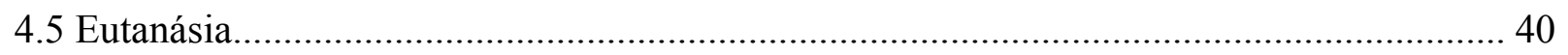

4.6 Manutenção do tumor de Ehrlich ............................................................................... 40

4.7 Obtenção das células tumorais ............................................................................................. 41

4.8 Inoculação nos animais............................................................................................. 42

4.9 Cultura primária de células do tumor de Ehrlich................................................................ 42

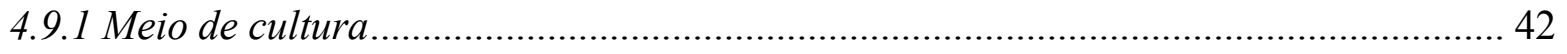

4.9.2 Obtenção e contagem de células tumorais ................................................................. 43

4.10 EXPERIMENTO I - Determinação do tempo de sobrevida dos animais portadores do tumor de Ehrlich na forma ascítica, tratados com o extrato etanólico, resíduo butanólico ou aquoso de P. Paniculata ..................................................................................................... 43

4.10.1 Delineamento experimental ................................................................................. 43

4.11 EXPERIMENTO II - Avaliação dos efeitos do resíduo butanólico sobre alguns parâmetros da toxicidade hepática e renal.......................................................................... 44 
4.11.1 Delineamento experimental

4.11.2 Coleta de sangue para a determinação da concentração de uréia e creatinina e da atividade das enzimas ALT, AST e $\gamma-G T$....

4.11.3 Coleta de órgãos para exame histopatológico.....

4.12 EXPERIMENTO III - Efeito do resíduo butanólico sobre o crescimento do tumor de

Ehrlich, forma ascítica. 46

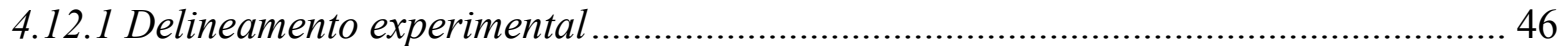

4.12.2 Avaliação do crescimento do tumor em sua forma ascítica ...................................... 46

4.13 EXPERIMENTO IV - Efeito do resíduo butanólico sobre alguns parâmetros da atividade macrofágica.

4.13.1 Delineamento experimental

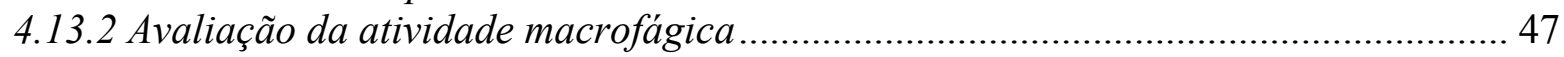

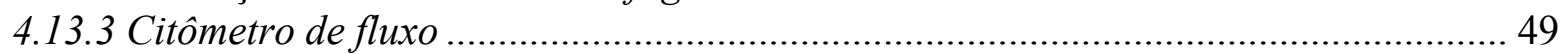

4.14 EXPERIMENTO V - Efeito do resíduo butanólico sobre o crescimento do tumor de

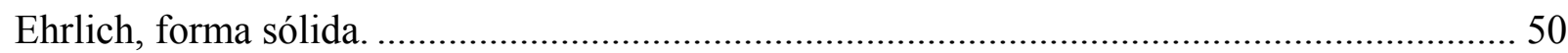

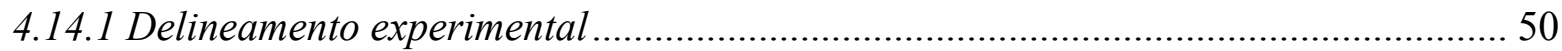

4.14.2 Avaliação do crescimento do tumor em sua forma sólida ......................................... 51

4.14.2.1 Mensuração da espessura das patas dos camundongos ....................................... 51

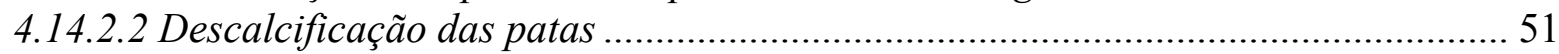

4.14.2.3 Quantificação da porcentagem de necrose na área tumoral .................................. 52

4.14.2.4 Marcação, por imunoistoquímica, das células em proliferação .............................. 54

4.14.2.5 Quantificação da proliferação celular ................................................................... 55

4.15 EXPERIMENTO VI - Efeito do resíduo butanólico sobre a atividade e/ou viabilidade de células do tumor de Ehrlich em cultura primária............................................................... 57

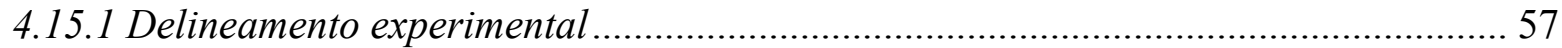

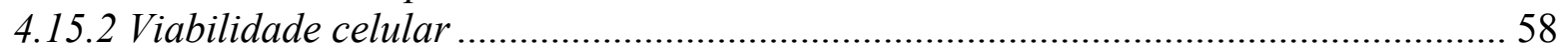

4.16 EXPERIMENTO VII - Efeito do resíduo butanólico sobre as fases do ciclo de células do tumor de Ehrlich em cultura primária, 48h após o tratamento ......................................... 58

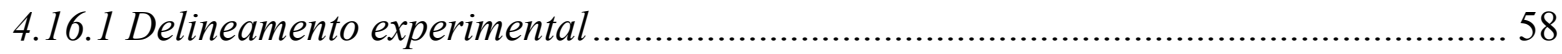

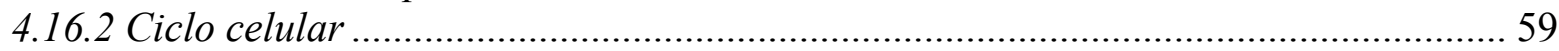

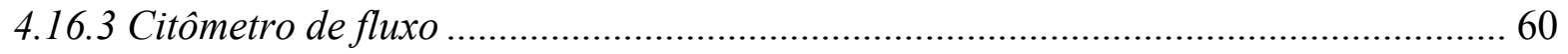




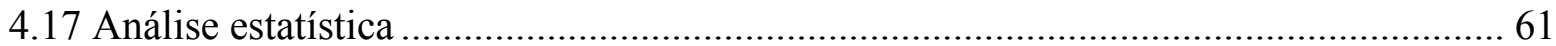

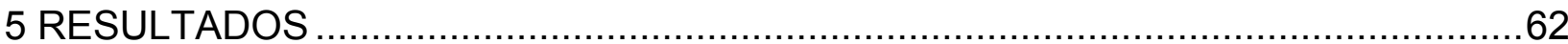

5.1 EXPERIMENTO I - Determinação do tempo de sobrevida dos animais portadores do tumor de Ehrlich na forma ascítica, tratados com o extrato etanólico, resíduo butanólico ou aquoso de $P$. Paniculata

5.2 EXPERIMENTO II - Avaliação dos efeitos do resíduo butanólico sobre alguns parâmetros da toxicidade hepática e renal 66

5.3 EXPERIMENTO III - Efeito do resíduo butanólico sobre o crescimento do tumor de Ehrlich, forma ascítica.

5.4 EXPERIMENTO IV - Efeito do resíduo butanólico sobre alguns parâmetros da atividade macrofágica.

5.5 EXPERIMENTO V - Efeito do resíduo butanólico sobre o crescimento do tumor de

Ehrlich, forma sólida. 78

5.5.1 Espessura dos coxins 78

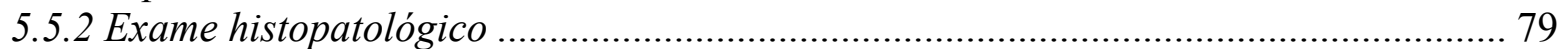

5.5.3 Porcentagem de necrose na área tumoral e quantificação da proliferação celular ... 82 5.6 EXPERIMENTO VI - Efeito do resíduo butanólico sobre a atividade e/ou viabilidade de células do tumor de Ehrlich em cultura primária.

5.7 EXPERIMENTO VII - Efeito do resíduo butanólico sobre as fases do ciclo de células do tumor de Ehrlich em cultura primária, 48h após o tratamento.

6 DISCUSSÃO 


\section{INTRODUÇÃO}

A utilização de plantas medicinais constitui muitas vezes o único recurso terapêutico de muitas comunidades e grupos étnicos. Este tipo de cultura medicinal desperta o interesse de pesquisadores de diversas áreas, enriquecendo os conhecimentos sobre a inesgotável fonte medicinal natural: a flora mundial.

As raízes de Pfaffia paniculata, planta de origem brasileira, conhecida no Brasil como "ginseng brasileiro" e "paratudo", têm sido utilizadas popularmente como tônicas, afrodisíacas e antidiabéticas (OLIVEIRA; AKISUE; AKISUE, 1980; OLIVEIRA 1986). A estas raízes são atribuídas também propriedades antineoplásicas.

Poucos estudos científicos relacionados a esta raiz, no entanto, são encontrados na literatura. Silva et al. (2004) demonstrou que as raízes desta planta exercem efeitos quimiopreventivos em camundongos submetidos a modelo de hepatocarcinogênese com dietilnitrosamina. Além disto, o tratamento com as raízes pulverizadas de Pfaffia paniculata causou uma diminuição do fluído ascítico em camundongos portadores do tumor de Ehrlich na forma ascítica (MATSUZAKI et al., 2003).

No presente trabalho, avaliamos os efeitos do tratamento com o extrato etanólico ou resíduos aquoso ou butanólico de $P$. paniculata, sobre o desenvolvimento do tumor de Ehrlich em camundongos, além dos efeitos do resíduo butanólico sobre as células deste tumor in vitro. Os parâmetros avaliados foram a sobrevida, o crescimento do tumor e a atividade macrofágica de animais portadores deste tumor na forma ascítica. Os efeitos do tratamento sobre o crescimento do tumor em sua forma sólida também foram avaliados. In vitro, os parâmetros avaliados foram a viabilidade celular e a porcentagem 
de células hipodiplóides ou nas fases G1(gap 1), S (síntese) ou G2/M (gap 2 e mitose) do ciclo celular. 


\section{REVISÃO DE LITERATURA}

\subsection{Neoplasias}

De acordo com o Instituto Nacional do Câncer (Inca), pouco mais de 2 milhões de brasileiros morreram de câncer entre 1979 e 2002.

Segundo Beremblum (1970), uma neoplasia é uma massa anormal de tecido cujo crescimento excede e é incoordenado com o de tecidos normais, persistindo de maneira excessiva após a cessação do estímulo que provocou a alteração. O conceito elaborado por Evans (1993) refletiu a compreensão gerada com o advento da biologia molecular e genética, em que "os cânceres são conseqüências de alterações genéticas e epigenéticas, envolvendo uma variedade de genes que são fundamentais para os processos de crescimento, diferenciação celular e remoção celular programada".

O câncer é caracterizado por um acúmulo de alterações genéticas, conferindo à célula a propriedade de evasão dos mecanismos de controle homeostáticos, garantindo a sua própria sobrevivência e proliferação (HAHN; WEINBERG, 2002; LEROI; KOUFOPANOU; BURT, 2003). Para o seu surgimento é necessário que ocorra todo um processo, envolvendo várias etapas, denominado carcinogênese. O processo de

carcinogênese pode ser dividido em 4 fases: iniciação, promoção, manutenção e progressão (FARBER, 1984; BELTRÃO-BRAGA; TEIXEIRA; CHAMMAS, 2004).

Na etapa de iniciação, ocorrem alterações no DNA por meio de mutações, porém é necessário que estas mutações sejam herdáveis, ou seja, transmitidas para as células filhas, para gerar-se a doença (COTRAN; KUMAR; ROBBINS, 1989; 
BELTRÃO-BRAGA; TEIXEIRA; CHAMMAS, 2004). A promoção corresponde à etapa em que as células iniciadas proliferam em resposta a agentes promotores; na etapa de manutenção, estas células alteradas são mantidas na população, de maneira que o acúmulo de mutações decorrentes destas alterações é responsável pela progressão tumoral (BELTRÃO-BRAGA; TEIXEIRA; CHAMMAS, 2004).

Os genes envolvidos no surgimento do câncer podem ser divididos em 3 classes (MICHOR; IWASA; NOWAK, 2004): 1) “Gatepeekers”, constituídos pelos oncogenes e genes supressores tumorais, que regulam diretamente as vias de crescimento e diferenciação celular; 2) "Caretakers", cuja função é a manutenção da integridade do genoma celular. Mutações nestes genes causam instabilidade genética, com o acúmulo de alterações em outros genes que controlam diretamente a sobrevivência e morte celular; e 3) "Landscaper", em que alterações nestes genes contribuem para a transformação neoplásica das células, por alterar o microambiente em que estas se encontram.

Segundo Hanahan e Weinberg (2000), as alterações adquiridas por uma célula cancerosa podem ser agrupadas em: 1) Auto-suficiência quanto a fatores de crescimento; 2) Insensibilidade a fatores inibitórios de proliferação; 3) Evasão da apoptose; 4) Potencial replicativo infinito; 5) Angiogênese sustentada; e 6) Invasão tecidual e metástase.

A compreensão da biologia do câncer, assim como a identificação e o estudo de potenciais agentes antineoplásicos, estão sendo realizados graças, em parte, à disponibilidade de modelos experimentais, tanto in vivo quanto in vitro. 


\subsection{Tumor de Ehrlich}

A oncologia é a ciência que se ocupa em estudar a biologia, o desenvolvimento, o comportamento clínico e o tratamento das neoplasias. A oncologia experimental é um ramo desta ciência que utiliza modelos experimentais para a realização de seus estudos.

$\mathrm{Na}$ tentativa de se obter modelos experimentais que permitissem o estudo de neoplasias, vários tipos de tumores transplantáveis, utilizando animais de laboratório, foram desenvolvidos. Esses tumores transplantáveis têm permitido uma melhor compreensão da biologia tumoral, assim como o estudo dos efeitos de diversos agentes sobre a patogenia do processo.

Muitos dos atuais conceitos a respeito do processo de carcinogênese em humanos são fortemente influenciados por modelos de desenvolvimento de câncer em camundongos. Em relação e esse processo, há semelhanças e diferenças entre humanos e camundongos (SCHWARTZ; MOORE, 1977; AMES; SHIGENAGA; HAGEN, 1993; RENAN, 1993; HAHN; WEINBERG, 2002; RANGARAJAN; WEINBERG, 2003). Apesar de haver diferenças, porém, camundongos de laboratório representam uma ferramenta para o entendimento da complexa patogenia do câncer.

Em 1896, uma neoplasia originária de adenocarcinoma mamário espontâneo de camundongo fêmea, foi descrita por Paul Ehrlich, sendo denominada tumor de Ehrlich (TE) $(E H R L I C H, 1906)$. Em 1932, Loewenthal e Jahn descreveram pela primeira vez que células obtidas do TE, quando implantadas na cavidade peritoneal de camundongos, eram capazes de crescer em suspensão em um fluído ascítico. 
Este tumor pode crescer na forma ascítica, quando as células tumorais são inoculadas intraperitonealmente, ou na forma sólida, mediante inoculação das células tumorais no subcutâneo ou por via intramuscular (GUERRA, 1983).

Uma das vantagens da utilização deste modelo é a possibilidade da padronização do número de células a serem inoculadas em animais, tanto para o crescimento na forma ascítica como sólida, pois as células tumorais presentes no fluído ascítico podem ser facilmente quantificadas.

Após aproximadamente 7 dias da inoculação das células tumorais na cavidade peritoneal, nota-se a presença de grande quantidade de fluído discretamente viscoso e de aspecto leitoso, contendo células tumorais em sua grande maioria (DAGLI, 1989; GUERRA, 1983). Pode-se constatar que a maioria das células são pleomórficas, apresentando diâmetro de 2 a 3 vezes superior aos das hemácias. Os núcleos apresentam formas variáveis, com nucléolos únicos ou múltiplos, de diferentes tamanhos (DAGLI, 1989; GUERRA, 1983).

Por outro lado o tumor na forma sólida, neste mesmo período de evolução, apresenta-se como massa palpável e de consistência firme. Ao exame histopatológico, caracteriza-se por apresentar um parênquima indiferenciado e estroma delicado. As células tumorais são arredondadas e apresentam citoplasma escasso, núcleo central redondo ou ovóide, com nucléolos conspícuos e pleomorfismo celular evidente; além disto, figuras de mitose aberrantes são freqüentemente observadas (GUERRA, 1983).

Este tumor se desenvolve em várias linhagens de camundongos, não regredindo espontaneamente (SIGIURA, 1965). Chen e Watkins (1970) descreveram a perda de antígenos $\mathrm{H}-2$, denominação do complexo de histocompatibilidade principal (MHC) para 
camundongos, no TE, corroborando o fato deste tumor crescer em várias linhagens de camundongos.

Após a inoculação intraperitoneal deste tumor, o volume do fluído ascítico e o número de células tumorais aumentam com o tempo; a concentração de células tumorais, por outro lado, permanece constante (VINCENT; NICHOLLS, 1967).

Fastaia e Dumont (1976) sugeriram que um aumento da permeabilidade de capilares no peritôneo seria responsável pela formação deste fluído ascítico. Discutiram ainda, que a inoculação de células tumorais, primeiramente, deveria exercer um efeito irritante na cavidade peritoneal, levando a este aumento da permeabilidade capilar, e que a liberação de substâncias pelas células mortas causaria um aumento do processo inflamatório.

O tumor de Ehrlich, em sua forma ascítica, leva o hospedeiro à morte em um período de tempo mais curto quando comparado ao de animais portadores deste tumor na forma sólida (KLEIN; KLEIN, 1951). Os animais portadores do tumor ascítico vêm a óbito por diversos fatores: pela pressão mecânica exercida pelo aumento progressivo do fluído ascítico, pelo processo de hemorragia intraperitoneal ou por substâncias tóxicas liberadas pelas células tumorais degeneradas (HARVEIT, 1965; MAYER, 1966).

Harveit (1965) demonstrou que animais que apresentavam uma menor sobrevida após a inoculação de células tumorais intraperitonealmente, apresentavam um fluído ascítico mais hemorrágico, sugerindo que estes animais vinham a óbito devido à intensa hemorragia intraperitoneal. Nos animais que vinham a óbito mais tardiamente, o fluído ascítico era menos hemorrágico. A autora, no entanto, atribuiu à pressão mecânica exercida pelo fluído ascítico a causa de morte nestes animais. 


\subsection{Tumor de Ehrlich e imunologia tumoral}

Um fator importante no desenvolvimento de uma neoplasia é a resposta imunológica do hospedeiro. De acordo com o conceito de vigilância imunológica, inicialmente introduzido por Paul Ehrlich (ABBAS; LICTHMAN; POBER, 1944), as células do sistema imune devem estar aptas a reconhecer os antígenos tumorais, promovendo a morte de células neoplásicas e rejeição tumoral.

Na década de 50, o conceito de vigilância imunológica foi transformado em teoria, por Macfarlane Burnet e Lewis Thomas (ABBAS; LICTHMAN; POBER, 1944), definindo como células efetoras da vigilância contra tumores os linfócitos $T$ e $B$, as células natural killers e os macrófagos.

Apesar da presença de infiltrados inflamatórios, constituídos por macrófagos, linfócitos e leucócitos polimorfonucleares, no estroma ou na periferia de tecidos neoplásicos, ser descrita há muito tempo (UNDERWOOD, 1974), o significado clínico e biológico do infiltrado inflamatório na evolução tumoral ainda não foi totalmente esclarecido.

Estudos descritos na literatura demonstram que os macrófagos desempenham um importante papel no desenvolvimento tumoral (GOUGH et al., 2001). Além disso, sabe-se que macrófagos isolados de animais com tumor são capazes de lisar células tumorais, tanto in vivo quanto in vitro (EVANS; ALEXANDER, 1970; SEZZI, BELELLI, NISTA, 1972).

Foi demonstrado que os macrófagos podem fagocitar células tumorais previamente irradiadas ou mortas antes da inoculação intraperitoneal (SEZZI; BELELLI; 
NISTA, 1972; VORBRODT et al., 1973). Por outro lado, os macrófagos também podem favorecer a progressão tumoral, por exemplo, estimulando a neovascularização, ou liberando proteases na região tumoral, favorecendo a invasão (POLVERINI et al., 1977).

Tão importante quanto a presença de células inflamatórias é o estado funcional das mesmas. Na ativação de macrófagos ocorre a liberação de várias substâncias, dentre elas as espécies reativas de oxigênio, resultantes de uma seqüência de reações bioquímicas de alto consumo de oxigênio e conhecidas como burst oxidativo. Desta maneira, o burst oxidativo, além da capacidade de fagocitose, é um importante parâmetro para analisar o estado funcional de macrófagos.

Lala (1974), estudando animais portadores do TE na forma ascítica, demonstrou que a evolução tumoral é acompanhada pelo influxo de leucócitos polimorfonucleares, monócitos e linfócitos do sangue para a cavidade peritoneal.

Foi demonstrado também que o TE leva à ativação de macrófagos inflamatórios (GUERRA, 1983). Neste estudo, o TE, na forma sólida, inibiu o influxo celular para um foco inflamatório induzido pelo implante de filtro de nitrocelulose. Esta inibição foi observada apenas quando os filtros foram implantados no mesmo local em que as células tumorais foram inoculadas. Ainda, a presença do tumor sólido aumentou o potencial fagocitário e a capacidade de espraiamento dos macrófagos, porém, apenas no local do implante do tumor.

Fecchio (1989), estudando este mesmo tumor, demonstrou a presença de reação inflamatória no local de sua inoculação, com alterações nos padrões de migração celular. A presença do tumor ascítico inibiu o influxo de leucócitos 
polimorfonucleares para um foco inflamatório induzido por carragenina, no local do implante tumoral. Porém, o tumor, tanto na forma ascítica como sólida, não afetou o influxo de células inflamatórias para um foco induzido à distância do implante tumoral. Esses resultados sugerem que o tumor apresenta um efeito inibidor no influxo de leucócitos, e que este efeito é exercido localmente. Além disto, o tumor causou aumento de espraiamento de macrófagos, porém não induziu a liberação espontânea, ou estimulada, de água oxigenada pelos macrófagos peritoneais.

Desta maneira, a resposta imunológica do hospedeiro, assim como o estado funcional de macrófagos, parece desempenhar importante papel no desenvolvimento deste tumor.

\subsection{Modelos experimentais in vitro}

Na última década, esforços têm sido direcionados para a descoberta de novos agentes antineoplásicos baseados na identificação de alvos proteícos específicos, envolvidos no controle do crescimento celular (BRIDGES, 1996). Entretanto, uma etapa obrigatória, antes de se iniciar os estudos clínicos de um potencial agente antineoplásico, é a demonstração de sua habilidade de inibir o crescimento tumoral em modelos in vivo e in vitro.

Apesar da maior parte das drogas citotóxicas clinicamente disponíveis atualmente terem sido descobertas utilizando-se tumores transplantáveis em 
camundongos, linhagens celulares em cultura vêm desempenhando importante papel na descoberta e estudo de diversos agentes (GOLDIN; VENDITTI; MACDONALDS, 1981)

Desde a descoberta, na década de 50 , de que alguns tumores humanos poderiam ser propagados indefinidamente em cultura na presença de nutrientes adequados e fatores de crescimento, células tumorais em cultura têm sido extensivamente utilizadas para diversas finalidades.

Uma das desvantagens quanto à utilização de culturas celulares, no entanto, é a possibilidade da perda de características importantes originalmente apresentadas in vivo (BAGULEY; MARSHALL, 2004).

Neste sentido, culturas primárias, em relação a linhagens estabelecidas de células tumorais, apresentam menos alterações em relação aos tumores dos quais se originaram, pelo menos em relação a alguns parâmetros, como a duração do ciclo celular (BAGULEY; MARSHALL, 2004).

O ciclo celular é dividido em 4 fases. Durante 2 destas fases, a célula executa os dois eventos básicos para a divisão celular: geração de uma única cópia fiel de seu material genético (fase $S$, síntese) e distribuição de todos os componentes celulares entre 2 células filhas idênticas (fase $M$, mitose). As outras 2 fases do ciclo - G1 (gap 1) e G2 (gap 2) - são períodos em que as células, por meio de pontos de checagem, se preparam para completar as fases S e M com sucesso (MALUMBRES; BARBACID, 2001).

Baguley e Maeshall (2004) mostraram que a duração do ciclo celular de linhagens celulares é menor em comparação à duração do ciclo de células em cultura primária. Os autores sugerem que este fenômeno se deve à seleção de variantes 
celulares que cresceriam mais rapidamente, durante o processo de estabelecimento de uma linhagem celular. Estes mesmos autores demonstraram que o período de tempo em que as células permanecem nas fases S e G2/M é similar em cultura primária e em linhagens celulares. O período gasto na fase $\mathrm{G} 1$, entretanto, é maior em células de cultura primária. Sugere ainda que a duração do ciclo celular é inicialmente preservada, quando o tumor é submetido à cultura primária.

Desta maneira, provavelmente há uma maior similaridade entre a cultura primária de um tumor e o tumor apresentado in vivo, quanto ao grau de citotoxicidade exercido por uma determinada droga que atue preferencialmente na fase $\mathrm{G} 1$, em comparação a linhagens celulares.

Um dos parâmetros avaliados ao se estudar os efeitos de uma determinada droga sobre células em cultura é a viabilidade celular, podendo ser utilizado o ensaio baseado na metabolização dos sais de tetrazolium (MOSMANN, 1983).

Este ensaio depende da atividade da enzima succinato desidrogenase (SDH), componente do ciclo do ácido cítrico; esta enzima reside na membrana mitocondrial interna, necessitando de um sistema de transporte de elétrons para a sua função (FRUEHAUF, 2002). Desta maneira, a atividade desta enzima é uma medida da viabilidade mitocondrial e celular.

A atividade desta enzima é medida pela sua capacidade de converter o 3-[4,5dimethylthiazol 2-yl] -2,5-diphenyltetrazolium bromide (MTT) a um composto cristalizado de coloração azul. A quantidade de cristais formados é determinada pela mensuração da densidade óptica por espectrofotometria.

Este ensaio, no entanto, se utilizado isoladamente, não diferencia as alterações na atividade desta enzima mitocondrial das alterações no número de células viáveis. A 
determinação do conteúdo de DNA por citometria de fluxo, por outro lado, permite a determinação da porcentagem de células mortas, hipodiplóides (SPECTOR; GOLDMAN; LEINWAND, 1998). Estas duas técnicas, utilizadas conjuntamente, permitem determinar se há alterações no número de células viáveis.

\subsection{Pfaffia paniculata}

A utilização de plantas medicinais constitui, muitas vezes, o único recurso terapêutico de muitas comunidades e grupos étnicos. O alto custo e a toxicidade apresentada pelas drogas convencionais são um dos fatores que levam as pessoas a utilizarem plantas com supostas propriedades terapêuticas, mesmo na ausência de estudos científicos em relação à eficácia e à toxicidade destas plantas.

Várias abordagens para a seleção de espécies vegetais têm sido apresentadas na literatura, revisadas por Maciel, Pinto e Veiga Jr (2002), dentre elas: 1) abordagem randômica, ou seja, cujo único fator determinante para a escolha da planta seria a sua disponibilidade; 2) abordagem quimiotaxonômica ou filogenética, em que a seleção da espécie se deve à ocorrência de uma determinada classe química de substâncias em um gênero ou família; ou c) abordagem etnofarmacológica, selecionando-se a espécie baseada na sua utilização por um determinado grupo étnico.

Uma vez definida a espécie vegetal a ser estudada, define-se o local da coleta e realiza-se a identificação botânica da espécie. Após esta etapa, iniciam-se os estudos fitoquímicos e/ou farmacológicos, podendo ser realizada uma única coleta ou várias 
coletas; caso haja coleta em regiões diferentes, a identificação botânica deve ser realizada novamente (MACIEL; PINTO; VEIGA JR, 2002).

As raízes de Pfaffia paniculata ( $P$. paniculata) são amplamente utilizadas baseadas na medicina popular. Esta planta pertence à família Amaranthaceae, e cerca de 90 espécies de Pfaffia são conhecidas na América Central e na América do Sul. No Brasil, são descritas 27 espécies, encontradas nos estados da Amazônia, do Mato Grosso e de São Paulo (VIDAL; VIDAL, 1967).

Os principais componentes isolados das raízes desta planta incluem o estigmasterol, sitosterol, alantoína, ácido pfáffico e suas saponinas, denominadas pfaffosídeos A, B, C, D, E e F (TAKEMOTO et al., 1983; NISHIMOTO et al., 1984).

In vitro, o ácido pfáffico e as saponinas de $P$. paniculata inibiram o crescimento de células de melanoma (B-16) (NAKAl et al., 1984) e feocromocitoma (KATO et al., 1993).

In vivo, a administração oral de preparações de $P$. paniculata, por 24 semanas, inibiu o crescimento de linfoma tímico em camundongos (WATANABE et al., 2000). Silva et al. (2004) demonstrou que as raízes desta planta exercem efeitos quimiopreventivos em camundongos submetidos a modelo de hepatocarcinogênese com dietilnitrosamina. Neste estudo, houve uma diminuição no número e na incidência de lesões préneoplásicas nestes animais.

Além disto, a administração oral de raízes pulverizadas por 20 dias, levou a um menor desenvolvimento do fluído ascítico em camundongos portadores do TE, indicando um possível efeito antiinflamatório de $P$. paniculata (MATSUZAKI et al., 2003).

Outros estudos mostraram que o extrato etanólico de $P$. paniculata, administrado intraperitonealmente ou subcutaneamente em ratos, possui efeito analgésicoantiinflamatório em edema induzido por carragenina (MAZZANTI; BRAGHIROLI, 1994). 
Foram obtidos também efeitos antiinflamatórios com o extrato metanólico de Pfaffia iresinoides, outra espécie de Pfaffia, em alguns modelos de inflamação em ratos, quando administrado aos animais por via oral (TANIGUCHI et al., 1997).

As raízes ou extratos de $P$. paniculata são comercialmente encontrados sob a forma de cápsulas, contendo raízes e/ou extratos, ou sob a forma de soluções, contendo extratos. No entanto, deve-se ressaltar a falta de estudos científicos que comprovem a eficácia destas raízes e/ou extratos.

Os extratos representam porções contendo substâncias mais purificadas das raízes de uma planta, obtidas pela retirada por meio de um solvente, obtendo-se muitas vezes formulações farmacêuticas mais convenientes ao manuseio e administração.

O resíduo aquoso (RA), obtido a partir do extrato etanólico, normalmente contém açúcares livres, aminoácidos, ácidos orgânicos e outras substâncias hidrofílicas; o resíduo butanólico $(\mathrm{RB})$, também obtido do extrato etanólico, contém, entre outras substâncias, uma fração purificada de saponinas (SIMÕES et al., 2002). O objetivo do fracionamento do extrato etanólico é o de estudar, isoladamente, a ação de substâncias presentes no resíduo aquoso ou butanólico. 


\section{OBJETIVOS}

\subsection{Objetivo Geral}

Determinar os efeitos do extrato etanólico e resíduos butanólico e aquoso de $P$. paniculata sobre o desenvolvimento do tumor de Ehrlich em camundongos, bem como seus efeitos diretos sobre as células deste tumor em cultura.

\subsection{Objetivos Específicos}

3.2.1 Determinar o tempo de sobrevida de animais portadores do tumor de Ehrlich, forma ascítica, tratados ou não com o extrato etanólico, resíduos butanólico ou aquoso de $P$. paniculata.

3.2.2 Verificar se o resíduo butanólico causa toxicidade hepática e renal em camundongos.

3.2.3 Avaliar o efeito do resíduo butanólico sobre o desenvolvimento do tumor de Ehrlich, na forma ascítica e sólida.

3.2.4 Avaliar o efeito do resíduo butanólico sobre a atividade de macrófagos peritoneais, em camundongos portadores do tumor de Ehrlich, forma ascítica. 
3.2.5 Avaliar o efeito do resíduo butanólico $P$. paniculata sobre cultura primária do tumor de Ehrlich. 


\section{MATERIAL E MÉTODOS}

\subsection{Animais}

Foram utilizados camundongos machos Swiss com aproximadamente 60 dias de idade, pesando entre 30 a 40 gramas, provenientes do Biotério do Departamento de Patologia da Faculdade de Medicina Veterinária e Zootecnia - USP (FMVZ-USP). Durante todo o experimento, os animais permaneceram em caixas de policarbonato forradas com maravalha, mantidos em sala com aeração, exaustão e climatização controladas, com temperatura entre 22 e $24^{\circ} \mathrm{C}$, umidade relativa de $55 \%$ e ciclo de luz noite/dia de 12 horas, recebendo ração balanceada e água ad libitum. A utilização dos animais esteve de acordo com os princípios éticos de experimentação animal da Comissão de Bioética da FMVZ-USP, protocolo n 157/2002.

\subsection{Raízes de Pfaffia paniculata}

As raízes de $P$. paniculata foram gentilmente cedidas pelo Prof. Gokithi Akisue, e mantidas em sacos plásticos selados a vácuo até o momento do preparo do extrato e resíduos. A exsicata (no 37411) desse espécime encontra-se depositada no Herbário Goro Hashimoto. 


\subsection{Obtenção do extrato e resíduos de Pfaffia paniculata}

O preparo do extrato e resíduos das raízes de $P$. paniculata foi realizado no Instituto Biológico, sob supervisão da $\mathrm{Dr}^{\mathrm{a}}$. Mitsue Haraguchi, de acordo com protocolo estabelecido previamente (NISHIMOTO et al., 1984; HARAGUCHI et al.,2000). Resumidamente, as raízes pulverizadas foram misturadas com etanol $95 \%(0,5 \mathrm{Kg}$ de

raiz/ $L$ álcool), assim permanecendo por 3 a 4 dias. O extrato etanólico (EE) obtido foi concentrado em rotaevaporador sob pressão reduzida, à temperatura de $55^{\circ} \mathrm{C}$, para a eliminação do solvente. Parte deste extrato foi dissolvido em água, e a solução aquosa resultante fracionada por partição com butanol saturado com água em fração butanólica e fração aquosa. A fração aquosa foi liofilizada. A fração butanólica foi concentrada em rotaevaporador sob pressão reduzida, à temperatura de $55^{\circ} \mathrm{C}$, para a eliminação do solvente, sendo posteriormente mantida em dessecador até atingir peso constante. Os resíduos aquoso $(R A)$ e butanólico $(R B)$ obtidos foram mantidos em freezer a $-20^{\circ} \mathrm{C}$ até o momento da utilização.

O EE, RA e RB foram diluídos em água destilada e filtrados em microfiltros (Nalgene ${ }^{\circledR} 0,2 \mu \mathrm{m}$ ) para a utilização nos experimentos.

\subsection{Reagentes e soluções}

Albumina sérica bovina (Sigma $\left.{ }^{\circledR}\right)$ : utilizada na solução de diluição de anticorpo primário, utilizado na técnica de imunoistoquímica; 
Ácido fórmico (Reagen $\left.{ }^{\circledR}\right)$ : reagente utilizado na descalcificação das patas;

ALT (Celm®): kit utilizado para a determinação da atividade sérica de ALT (alanina aminotransferase);

> Anticorpo primário anti-PCNA (DAKO®): Anticorpo primário utilizado na técnica de imunoistoquímica para a marcação de células em proliferação;

AST (Celm $\left.{ }^{\circledR}\right)$ : kit utilizado para a determinação da atividade sérica de AST (aspartato aminotransferase);

$>$ Azida sódica (Sigma ${ }^{\circledR}$ ): utilizada na solução de diluição de anticorpo primário, utilizado na técnica de imunoistoquímica;

Azul de tripan (GIBCO $\left.{ }^{2}\right)$ : corante vital utilizado para contagem de células e determinação de viabilidade celular;

$>$ Cepa de Staphylococcus aureus ATCC 25923 (DIFCO ${ }^{\circledR}$ ): Bactéria utilizada para avaliar a atividade fagocítica realizada por macrófagos;

$>$ Creatinina $\left(\right.$ Celm $\left.{ }^{\circledR}\right)$ : kit utilizado para a determinação da concentração de creatinina sérica;

$>$ Diacetato 2'7' diclorofluoresceína (DCFH-DA) (Molecular Probes $\left.{ }^{\circledR}\right)$ : reagente utilizado na técnica de citometria de fluxo, para a avaliação do burst oxidativo de macrófagos;

> Diaminobenzidina $(\mathrm{DAB})\left(\mathrm{SIGMA}{ }^{\circledR}\right)$ : Reagente utilizado para a revelação da marcação na técnica de imunoistoquímica;

EDTA (etilenodiamino-tetracética-dissódica) (Reagen $®)$ : utilizado para o bloqueio de fagocitose; 
Etanol (Synth $\left.{ }^{\circledR}\right)$ : utilizado na obtenção do extrato de Pfaffia paniculata e na desidratação/hidratação dos cortes histológicos na técnica de imunoistoquímica;

Formaldeído (Synth $\left.{ }^{\circledR}\right)$ : utilizado para a fixação de material submetido à descalcificação;

$>$ Fungizone $\left(\mathrm{GIBCO}{ }^{\circledR}\right)$ - antifúngico a base de anfotericina $\mathrm{B}$ para meio de cultura celular;

> GAMA -GT (Celm $\left.{ }^{\circledR}\right)$ : kit utilizado para a determinação da atividade sérica de $\gamma$ glutamil-transferase;

$>$ Hematoxilina (Inlab®): corante utilizado a fim de se contracorar os cortes submetidos à imunoistoquímica;

Hepes (Gibco®): utilizado no preparo de meio de cultura;

lodeto de propídeo $(\mathrm{PI})(\mathrm{SIGMA} \AA)$ : reagente utilizado na técnica de citometria de fluxo, para avaliação de fagocitose por macrófagos e ciclo celular de células tumorais;

Kit LSAB (DAKO $\left.{ }^{\circ}\right)$ - reagente que contém anticorpo secundário e complexo estreptavidina-biotina, utilizado na técnica de imunoistoquímica;

Metacarn: solução utilizada para a fixação de material, constituída por $60 \%$ de metanol (Synth ${ }^{\circledR}$ ), 30\% de clorofórmio (Synth ${ }^{\circledR}$ ) e 10\% de ácido acético (Synth®).

Miristato-acetato de forbol (PMA) (Sigma $\left.{ }^{\circledR}\right)$ : utilizado para ativar o burst oxidativo de macrófagos;

MTT (3-(4,5-dimethylthiazol-2-yl)-2,5-diphenyl tetrazolium bromide) (Amresco $\left.{ }^{\circledR}\right)$ : sal utilizado na determinação da viabilidade celular; 
PBS (salina tamponada com fosfato) - solução estoque 10x concentrada

$\begin{array}{lcc}\mathrm{Na}_{2} \mathrm{PO}_{4} \cdot 7 \mathrm{H}_{2} \mathrm{O} & (\text { Sigma } & \\ \mathrm{Na}_{2} \mathrm{PO}_{4} \mathrm{H}_{2} \mathrm{O} & (\text { Sigma } & \\ & & 26,79 \mathrm{~g} \\ \mathrm{NaCl} & (\text { Sigma } & \\ & & 4,14 \mathrm{~g} \\ \mathrm{H}_{2} \mathrm{O} \text { mili-Q } & & 82,0 \mathrm{~g} \\ & & 1000 \mathrm{ml}\end{array}$

Para uso, esta solução foi diluída a 1:10 em $\mathrm{H}_{2} \mathrm{O}$ mili-Q, mantendo-se um $\mathrm{pH}=7,2$ a 7,4

Penicilina/estreptomicina (Cultilab®): antibióticos utilizados na cultura de células;

Peróxido de Hidrogênio (Merck $\left.{ }^{\circledR}\right)$ - utilizado para bloqueio de peroxidase endógena na técnica de imunoistoquímica;

RNaseA (Invitrogen $\left.{ }^{\circledR}\right)$ : enzima utilizada na técnica de avaliação do ciclo celular por citometria de fluxo;

RPMI 1641 (GIBCO $\left.{ }^{\circledR}\right)$ : meio de cultura celular;

Solução de lise: solução composta por 9 partes de cloreto de amônio (Merck®) a $0,16 \mathrm{M}$ em 1 parte de tampão Tris (GIBCO $\left.{ }^{\circledR}\right)$ a $0,17 \mathrm{M}$, ou composta por $\mathrm{NaCl}$ (Synth®) a 0,2 e 1,6\%, para a lise de hemácias;

Soro Fetal Bovino (GIBCO $\left.{ }^{\circledR}\right)$ : utilizado no meio de cultura;

> Tampão citrato: solução composta por 1 parte de ácido cítrico (Synth®) a 0,01M para 3 partes de citrato de sódio (Synth ${ }^{\circledR}$ ) a $0,01 \mathrm{M}, \mathrm{pH}=6$, utilizada para o desmascaramento antigênico na técnica de imunoistoquímica;

> Tripsina $\left(\right.$ Cultilab $\left.{ }^{\circledR}\right)$ : enzima utilizada para se coletar as células aderentes em cultura; 
Triton (Sigma $\left.{ }^{\circledR}\right)$ : utilizado para a permeabilização de células para a avaliação do ciclo celular, por citometria de fluxo;

> UREIA ES (Celm $\left.{ }^{\circledR}\right)$ : kit utilizado para a determinação da concentração de uréia sérica;

> Xilol (Synth $\left.{ }^{\circledR}\right)$ : utilizado na desidratação/hidratação dos cortes na técnica de imunoistoquímica.

\subsection{Eutanásia}

Os animais foram eutanasiados por anestesia profunda em câmara de $\mathrm{CO}_{2}$ ou por deslocamento cervical.

\subsection{Manutenção do tumor de Ehrlich}

A manutenção do tumor é realizada no Biotério do Departamento de Patologia da FMVZ-USP, por meio de transplantes intraperitoneais semanais das células neoplásicas nos camundongos, que permanecem neste mesmo biotério. 


\subsection{Obtenção das células tumorais}

Para a obtenção das células neoplásicas, camundongos com aproximadamente 7 dias de evolução do tumor ascítico de Ehrlich foram eutanasiados, e o fluído ascítico aspirado com seringas e agulhas descartáveis, após laparotomia, sendo realizada a lise de hemácias quando o fluído apresentava-se com aspecto hemorrágico. Assim, antes da centrifugação, adicionava-se à suspensão $20 \mathrm{~mL}$ de solução de $\mathrm{NaCl}$, $2 \%$, aguardava-se 20 segundos, sendo então adicionado $20 \mathrm{~mL}$ de solução de $\mathrm{NaCl}$ 1,6\%.

A esta suspensão celular foi adicionado PBS $1 \mathrm{x}$, sendo então centrifugada a 1500 rpm por 5 minutos, desprezado o sobrenadante, sendo este procedimento repetido mais 2 vezes. Por fim as células tumorais foram ressuspensas novamente em PBS 1x. Para a determinação da concentração de células tumorais presentes nesta suspensão, uma alíquota da suspensão foi diluída, sendo realizada a contagem de células na câmara de Neubauer, e a viabilidade determinada com a utilização do azul de tripan. Para a obtenção do número de células $/ \mathrm{mL}$, foi utilizada a fórmula descrita por Campbell (1986).

As células tumorais foram então ressuspensas em PBS 1x, nas concentrações de $1,25 \times 10^{7}$ por $\mathrm{mL}$ (experimentos com o tumor na forma ascítica) ou $5 \times 10^{7}$ células por $\mathrm{mL}$ (experimentos com o tumor na forma sólida). O preparo desta suspensão foi realizado de acordo com protocolo previamente estabelecido (DAGLI; GUERRA; SALDIVA, 1992). 


\subsection{Inoculação nos animais}

Os camundongos utilizados nos experimentos com o tumor na forma sólida foram sedados com éter, e com o auxílio de seringas e agulhas descartáveis, foram inoculados com $0,05 \mathrm{~mL}$ de suspensão, contendo $2,5 \times 10^{6}$ células tumorais no coxim plantar esquerdo. Os camundongos utilizados nos experimentos com o tumor na forma ascítica foram inoculados, com o auxílio de seringas e agulhas descartáveis, intraperitonealmente, com 0,4 mL de suspensão contendo 5,0 × $10^{6}$ células do tumor de Ehrlich. Foram utilizadas apenas suspensões celulares com no mínimo $90 \%$ de viabilidade.

\subsection{Cultura primária de células do tumor de Ehrlich}

\subsubsection{Meio de cultura}

O meio RPMI liofilizado utilizado foi diluído em $1 \mathrm{~L}$ de água miliQ, sendo adicionado $2 \mathrm{~g}$ de $\mathrm{NaHCO}_{3}, 2,32 \mathrm{~g}$ de Hepes, $10000 \mathrm{U}$ de penicilina, $10000 \mu \mathrm{g}$ de estreptomicina e anfotericina $\mathrm{B} 500 \mathrm{Ug}$. $\mathrm{O}$ pH foi ajustado para 7.4 , sendo adicionado $10 \%$ de soro fetal bovino (SFB) antes da utilização do meio de cultura. 


\subsubsection{Obtenção e contagem de células tumorais}

Para a obtenção das células neoplásicas, camundongos com aproximadamente 7 dias de evolução do tumor ascítico de Ehrlich foram eutanasiados, e o fluído ascítico aspirado com seringas e agulhas descartáveis, após laparotomia.

Os procedimentos realizados para a lise de hemácias, quando necessária, centrifugação e determinação da concentração de células tumorais foram os mesmos que os descritos anteriormente. As células tumorais, no entanto, foram ressuspensas em meio de cultura contendo $10 \%$ se soro fetal bovino, na concentração de $5 \times 10^{5}$ células por $\mathrm{mL}$.

\subsection{EXPERIMENTO I - Determinação do tempo de sobrevida dos animais portadores do tumor de Ehrlich na forma ascítica, tratados com o extrato etanólico, resíduo butanólico ou aquoso de P. Paniculata}

\subsubsection{Delineamento experimental}

Foram utilizados 50 camundongos, separados em 10 grupos de 5 animais cada: 9 grupos tratados e 1 grupo controle. Os animais dos grupos tratados receberam diariamente, por gavagem, EE, RA ou RB, nas concentrações de 50, 100 ou 200mg/Kg; 
os animais pertencentes ao grupo controle receberam água destilada, sob as mesmas condições. No $8^{\circ}$ dia do tratamento, todos os camundongos foram inoculados no peritôneo, com 0,4 mL de suspensão contendo $5 \times 10^{6}$ células do TE. Os animais continuaram recebendo os respectivos tratamentos ou a água destilada até óbito, sendo o intervalo entre a inoculação do tumor e o óbito considerado o tempo de sobrevida.

\subsection{EXPERIMENTO II - Avaliação dos efeitos do resíduo butanólico sobre alguns parâmetros da toxicidade hepática e renal}

\subsubsection{Delineamento experimental}

Foram utilizados 20 animais, separados em 1 grupo tratado e 1 grupo controle, de 10 animais cada. Os animais do grupo tratado receberam diariamente, por gavagem, RB na concentração de $200 \mathrm{mg} / \mathrm{Kg}$, durante 14 dias; os animais pertencentes ao grupo controle receberam água destilada, sob as mesmas condições. Os animais foram pesados a cada 3 dias. No $15^{\circ}$ dia do período experimental, os animais foram eutanasiados. 
4.11.2 Coleta de sangue para a determinação da concentração de uréia e creatinina e da atividade das enzimas ALT, AST e $\gamma-G T$

Após a eutanásia, foi realizada a coleta de sangue a partir da veia cava caudal. O sangue foi centrifugado a $2500 \mathrm{rpm}$ por 3 minutos, e o soro obtido foi mantido a $-20^{\circ} \mathrm{C}$ até o momento de sua utilização.

As concentrações de uréia e de creatinina no soro foram determinadas por metodologia enzimática-colorimétrica e cinética, respectivamente, utilizando-se os kits UREIA ES e CREATININA, em analisador bioquímico automático (Celm ${ }^{\circledR}$, SBA-200). As atividades das enzimas alanina aminotranferase (ALT), aspartato aminotransferase (AST) e $\gamma$-glutamiltransferase $(\gamma$--GT) foram determinadas por metodologia cinética, utilizando-se os kits ALT, AST e GAMA -GT, respectivamente, em analisador bioquímico automático (Celm®, SBA-200).

\subsubsection{Coleta de órgãos para exame histopatológico}

Após a eutanásia, foi realizada a coleta de fígado, rim e baço. Os órgãos foram fixados em metacarn por 12 horas, transferidos para álcool 95\%, e enviados ao Laboratório de Histologia do Departamento de Patologia da FMVZ-USP, para serem incluídos em parafina, cortados com $5 \mu \mathrm{m}$ de espessura e corados pela hematoxilinaeosina (H\&E). 


\subsection{EXPERIMENTO III - Efeito do resíduo butanólico sobre o crescimento do tumor de Ehrlich, forma ascítica.}

\subsubsection{Delineamento experimental}

Foram utilizados 12 animais, separados em 1 grupo tratado e 1 grupo controle, de 6 animais cada. Os animais pertencentes ao grupo tratado receberam diariamente, por gavagem, RB na concentração de $50 \mathrm{mg} / \mathrm{Kg}$; os animais pertencentes ao grupo controle receberam água destilada, sob as mesmas condições. No $8^{\circ}$ dia do período experimental, todos os camundongos foram inoculados, intraperitonealmente, com $0,4 \mathrm{~mL}$ de suspensão contendo $5 \times 10^{6}$ células do TE. Os animais continuaram recebendo os respectivos tratamentos ou a água destilada e, no $15^{\circ}$ dia do período experimental (7 dias após a inoculação do tumor), os animais foram eutanasiados.

\subsubsection{Avaliação do crescimento do tumor em sua forma ascítica}

Após a eutanásia, foi coletado o líquido ascítico total, para a mensuração do volume e do número de células tumorais presentes, de acordo com Dagli, Guerra e Saldiva (1992). 


\subsection{EXPERIMENTO IV - Efeito do resíduo butanólico sobre alguns parâmetros da atividade macrofágica}

\subsubsection{Delineamento experimental}

Foram utilizados 13 animais, separados em 1 grupo tratado e 1 grupo controle. Os animais do grupo tratado (7 animais) receberam diariamente, por gavagem, RB na concentração de $50 \mathrm{mg} / \mathrm{Kg}$, durante 8 dias; os animais pertencentes ao grupo controle (6 animais) receberam água destilada, sob as mesmas condições. No $8^{\circ}$ dia do período experimental, todos os camundongos foram inoculados, intraperitonealmente, com $0,4 \mathrm{~mL}$ de suspensão contendo $5 \times 10^{6}$ células do TE. Após 24 horas da inoculação do tumor, os animais foram eutanasiados.

\subsubsection{Avaliação da atividade macrofágica}

Após a eutanásia, foram injetados $5 \mathrm{~mL}$ de PBS intraperitonealmente e, após realização de massagem da cavidade, o lavado resultante foi aspirado com o auxílio de seringas e agulhas descartáveis e colhido em tubos de polipropileno. A lise de hemácias foi realizada utilizando-se solução composta de $0,16 \mathrm{M}$ de cloreto de amônio e 0,17M de tampão Tris. Foram adicionados $5 \mathrm{~mL}$ desta solução em cada tubo, centrifugados a 1200 rpm por 10 minutos, e o sobrenadante descartado. Após a lise, as células foram ressuspensas em PBS e, para a quantificação dos macrófagos 
peritoneais, as células foram diluídas em azul de tripan e contadas em câmara de Neubauer.

O método proposto por Hasui et al. (1989) foi utilizado para a análise do bust oxidativo desencadeado por diferentes estímulos e para a análise da fagocitose. Os estímulos utilizados para induzir o burst oxidativo foram o Staphylococcus aureus (S. aureus) e o PMA (miristato-acetato de forbol). O S aureus conjugado ao PI (iodeto de propídeo) foi utilizado para a análise de fagocitose.

Assim, após a contagem de macrófagos do lavado peritoneal, $100 \mu \mathrm{L}$ de cada amostra, contendo aproximadamente $2 \times 10^{5}$ macrófagos, foram incubados em soluções contendo PBS e DCFH-DA (diacetato 2'7' diclorofluoresceína) ou S. aureus + PI ou PMA, ou apenas em PBS, em tubos de citometria, conforme esquematizado abaixo:

\section{Tubo $2 \times 10^{5}$ macrófagos DCFH-DA S. aureus + PI PMA PBS}

\begin{tabular}{|c|c|c|c|c|c|}
\hline A & $100 \mu \mathrm{L}$ & & & & $1000 \mu \mathrm{L}$ \\
\hline B & $100 \mu \mathrm{L}$ & $200 \mu \mathrm{L}$ & & & $800 \mu \mathrm{L}$ \\
\hline C & $100 \mu \mathrm{L}$ & & $100 \mu \mathrm{L}$ & & $900 \mu \mathrm{L}$ \\
\hline D & $100 \mu \mathrm{L}$ & $200 \mu \mathrm{L}$ & $100 \mu \mathrm{L}$ & & $700 \mu \mathrm{L}$ \\
\hline $\mathbf{E}$ & $100 \mu \mathrm{L}$ & $200 \mu \mathrm{L}$ & & $100 \mu \mathrm{L}$ & $700 \mu \mathrm{L}$ \\
\hline
\end{tabular}


Após a incubação, foram adicionados $2 \mathrm{~mL}$ de solução de EDTA gelado a 3mM, nos tubos C e D, a fim de se interromper a reação, sendo então todos os tubos centrifugados a 1200rpm por 10 minutos. Após a centrifugação, o sobrenadante foi desprezado e as células ressuspensas em $500 \mu \mathrm{L}$ de EDTA (3mM) gelado para a leitura das amostras em citômetro de fluxo.

\subsubsection{Citômetro de fluxo}

Foi utilizado um citômetro de fluxo (Becton Dickinson Immunocytometry System, San Jose, CA, USA) conectado a um computador (Machintosh Apple, CA, USA). Foram adquiridos e analisados no mínimo 3000 eventos por meio de um software - Cell Quest Pro (Becton Dickinson Immunocytometry System, San Jose, CA, USA). As populações de interesse (macrófagos) foram analisadas por meio de gates, excluindo assim outros tipos celulares das amostras. Além disso, para todos es experimentos o aparelho foi calibrado com um tubo "branco", como controle de refringência.

As subpopulações celulares foram reconhecidas por meio das propriedades de FSC - Forward Scatter e SSC - Side Scatter, que avaliam o tamanho e a complexidade interna, respectivamente. As fluorescências foram adquiridas em escala logarítimica. A fluorescência verde do DCFH foi detectada pelo leitor FL-1 (530 $\pm 30 \mathrm{~nm})$ e a fluorescência vermelha do PI detectada pelo leitor FL-2 (585₫42nm). A quantificação da capacidade de fagocitose e a análise do burst oxidativo foram estimadas pela intensidade média da fluorescência/célula emitida pelo PI e pelo DCFH, respectivamente. A porcentagem de fagocitose foi calculada por meio do número de 
macrófagos fluorescentes dividido pelo número total destas células e multiplicadas por 100 (GOMES, 2003).

\subsection{EXPERIMENTO V - Efeito do resíduo butanólico sobre o crescimento do tumor de Ehrlich, forma sólida.}

\subsubsection{Delineamento experimental}

Foram utilizados 34 animais, separados em 3 grupos tratados e 1 grupo controle. Os animais do grupo tratado receberam diariamente, por gavagem, RB na concentração 50 (9 animais), 100 (8 animais) ou 200 mg/Kg (8 animais); os animais pertencentes ao grupo controle (9 animais) receberam água destilada, sob as mesmas condições. No $8^{\circ}$ dia do tratamento, todos os camundongos foram inoculados, no coxim plantar esquerdo, com suspensão contendo $2,5 \times 10^{6}$ células tumorais. Os animais continuaram recebendo os respectivos tratamentos ou a água destilada e, 8 dias após a inoculação do tumor, foram eutanasiados. A espessura das patas foi acompanhada durante os 8 dias subseqüentes à inoculação do tumor na pata. 
4.14.2 Avaliação do crescimento do tumor em sua forma sólida

4.14.2.1 Mensuração da espessura das patas dos camundongos

A espessura das patas foi acompanhada durante os 8 dias subseqüentes à inoculação do tumor de Ehrlich no coxim plantar, com o auxílio de paquímetro digital (Starret $\left.{ }^{\circledR}\right)$. A espessura da pata foi medida antes da inoculação do tumor, e este valor inicial foi subtraído dos valores obtidos nos dias subseqüentes à inoculação do tumor.

\subsubsection{Descalcificação das patas}

Após a eutanásia, as patas foram coletadas e mantidas em solução de formaldeído a $10 \%$ por 1 semana, sendo então descalcificadas em ácido fórmico $5 \%$ por 9 dias. Após este período, as patas foram lavadas em água corrente por aproximadamente 6 horas e transferidas para álcool $70 \%$, sendo então enviadas ao Laboratório de Histologia da FMVZ-USP para serem incluídas em parafina, cortadas com $5 \mu \mathrm{m}$ de espessura e coradas pela hematoxilina-eosina. 
4.14.2.3 Quantificação da porcentagem de necrose na área tumoral

A quantificação das áreas de necrose em meio à massa tumoral foi realizada nas lâminas contendo coxim plantar coradas pela hematoxilina-eosina. Para tanto, utilizouse o sistema de Análise de Imagens Computadorizado (Image Pro-plus) do Laboratório de Oncologia Experimental da FMVZ-USP. Esse sistema compõe-se de um microscópio óptico acoplado a uma câmara de vídeo e um computador que possui uma placa digitalizadora.

As áreas de necrose em meio à massa tumoral foram observadas ao microscópio, transmitidas ao monitor, e contornadas com um cursor eletrônico, sendo obtidos os respectivos valores numéricos em $\mathrm{mm}^{2}$, utilizando-se o programa Image ProPlus.

As áreas de necrose foram observadas ao microscópio utilizando objetivas de 10 e 20x, porém as imagens foram transmitidas ao monitor utilizando a objetiva de $0.25 x$, a fim de se obter a imagem contendo o coxim em sua total plenitude, conforme ilustra a figura 1. 


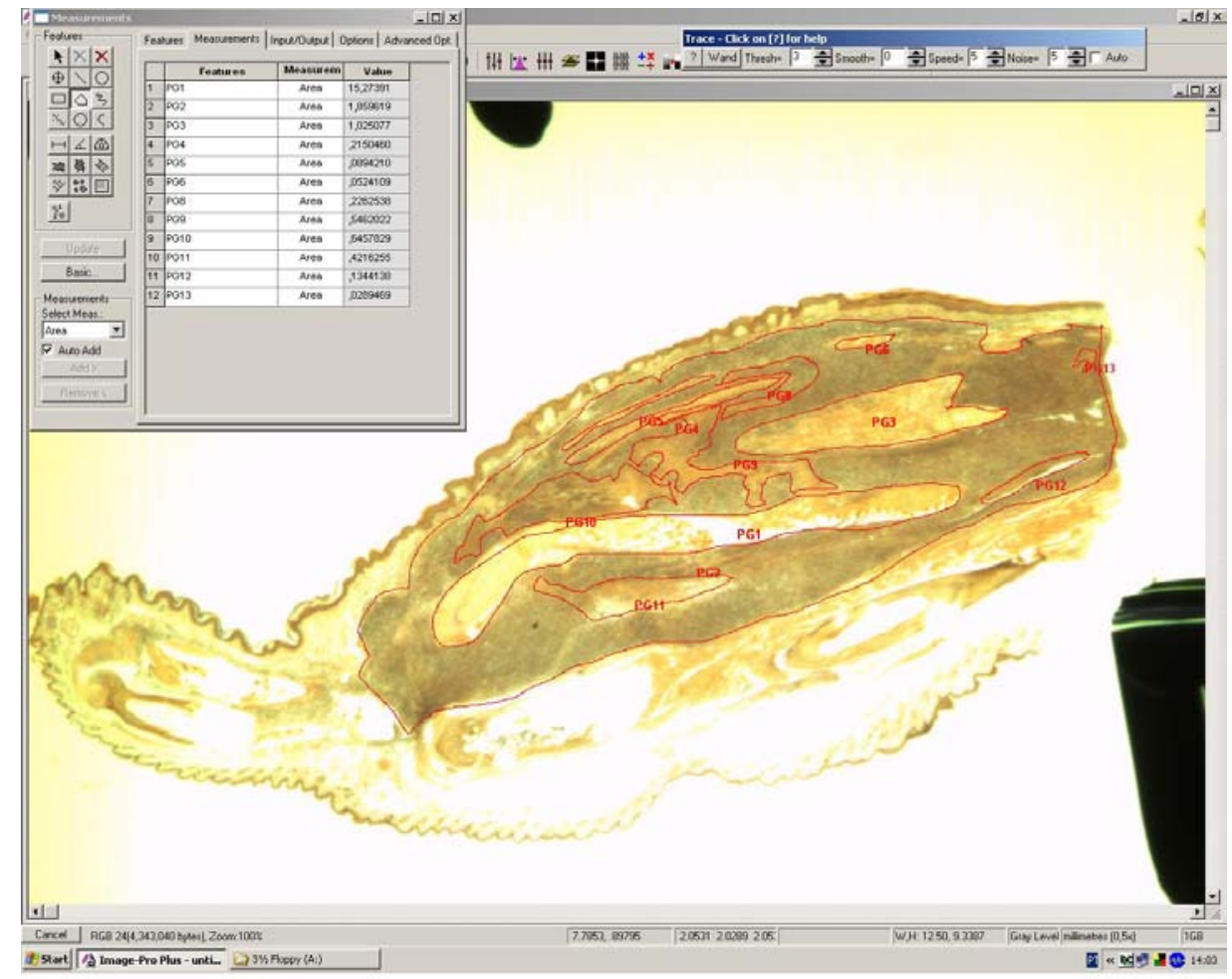

Figura 1: Áreas de necrose, contornadas em vermelho, em meio à massa tumoral, também contornada em vermelho, de coxim plantar de camundongo portador do tumor de Ehrlich na forma sólida.

Para a obtenção da porcentagem da área de necrose em meio a massa tumoral, foi utilizada a seguinte fórmula:

\% área de necrose = área de necrose (x 100) / área total (área de necrose + área de tumor) 
4.14.2.4 Marcação, por imunoistoquímica, das células em proliferação

A proliferação de células do TE no coxim plantar foi avaliada por imunoistoquímica, utilizando-se anticorpos anti-PCNA (antígeno nuclear de proliferação celular), nos cortes histológicos descritos anteriormente. A técnica empregada, descrita abaixo, seguiu a metodologia descrita por Hsu, Raine e Fanger (1981).

Desta maneira, os cortes histológicos foram processados pelas técnicas usuais de desparafinação em xilol e hidratação em seqüência de álcoois (absoluto, 95\% e 70\%) e água destilada. Para a recuperação antigênica, as lâminas foram fervidas em solução tampão citrato por 12 minutos em forno de microondas. Após o resfriamento, as lâminas foram lavadas 3 vezes com PBS. A peroxidase endógena foi bloqueada pela incubação, por 30 minutos, em solução contendo $80 \%$ de álcool metílico e $20 \%$ de peróxido de hidrogênio 30 volumes. Em seguida, as lâminas foram lavadas 3 vezes com PBS.

Os cortes foram incubados com o anticorpo anti-PCNA na diluição de 1: 1600, durante uma noite em câmara úmida a $4^{\circ} \mathrm{C}$. A solução de diluição do anticorpo era composta de $0,5 \mathrm{~mL}$ de azida sódica a $5 \%, 0,25 \mathrm{~mL}$ de albumina bovina e $12 \mathrm{~mL}$ de PBS.

A etapa seguinte consistiu da incubação com anticorpo secundário, sendo utilizado o kit LSAB. Assim, os cortes foram incubados com solução contendo antiimunoglobulina de camundongo biotinilada por 30 minutos, sendo então lavados 3 vezes com PBS. Em seguida foram incubados com solução contendo complexo estreptavidina-peroxidase, por 30 minutos, sendo então lavados 3 vezes com PBS. 
A revelação foi feita aplicando-se sobre os cortes, por 1 minuto, $200 \mu \mathrm{L}$ de solução de diaminobenzidina a $0,05 \%$ em PBS. Imediatamente antes da utilização, acrescentou-se $0,75 \mu \mathrm{L}$ de peróxido de hidrogênio 30 volumes por $\mathrm{mL}$ da solução cromógena. Em seguida as lâminas foram lavadas 2 vezes com PBS e 1 vez com água destilada, contracoradas pela hematoxilina por 1 minuto, desidratadas, diafanizadas e montadas com resina sintética e lamínula.

\subsubsection{Quantificação da proliferação celular}

A quantificação das células em proliferação foi realizada por meio da contagem do número de células positivas para o PCNA, em microscópio de luz, utilizando objetiva de 20x. Para cada coxim, foram contadas as células presentes nos 6 quadrantes centrais de 8 campos escolhidos ao acaso, conforme ilustra a figura 2 . fórmula:

A porcentagem de células PCNA positivas foi calculada segundo a seguinte $\%$ células PCNA positivas $=$ número de células PCNA positivas $\times 100 /$ número de células totais

Foram contadas no mínimo 1000 células totais por coxim plantar. 


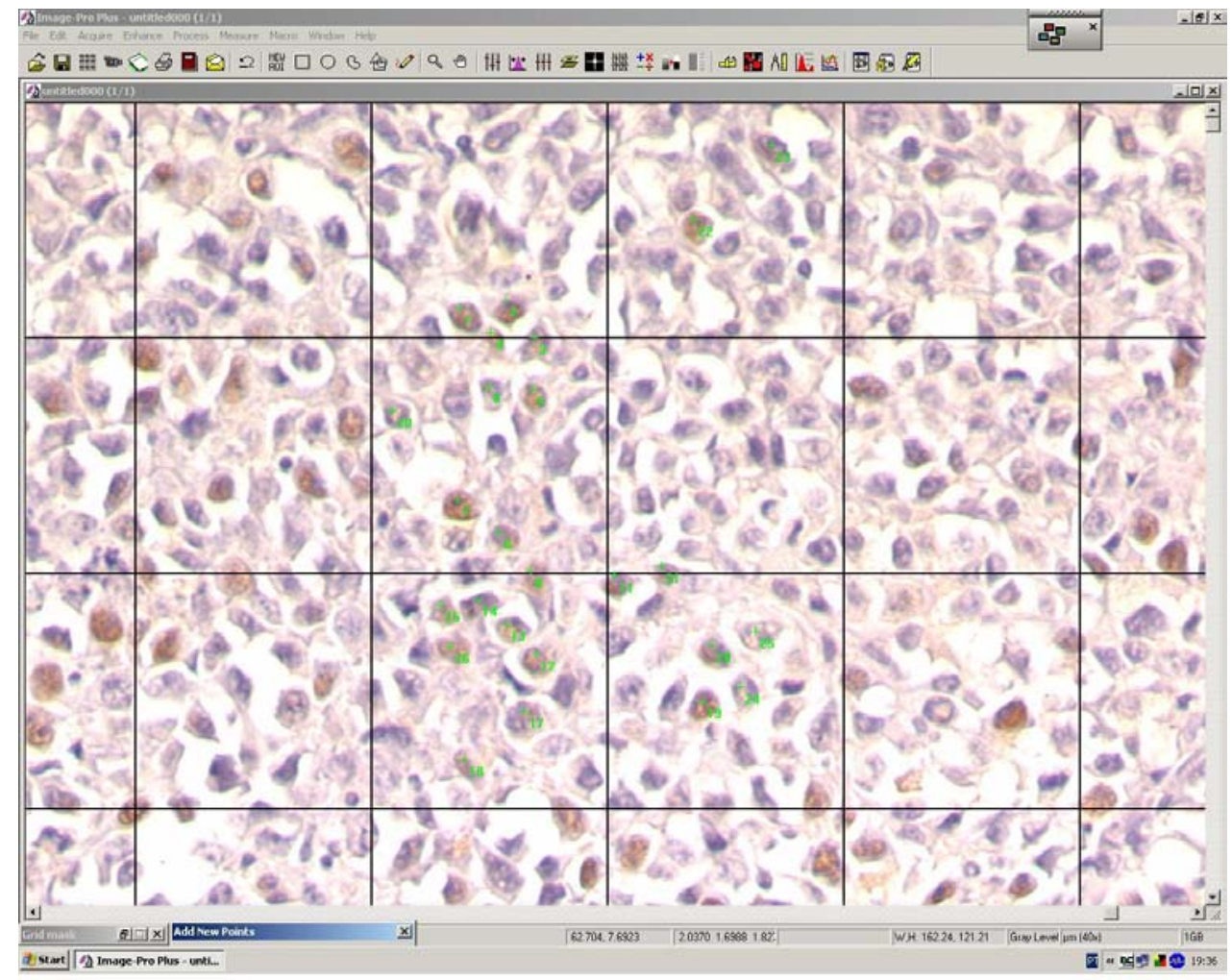

Figura 2 - Quadrantes centrais (6) de 1 campo, objetiva de 20x. As células positivas para o PCNA presentes nos 6 quadrantes centrais estão indicadas com numerais (em verde). 


\subsection{EXPERIMENTO VI - Efeito do resíduo butanólico sobre a atividade e/ou viabilidade de células do tumor de Ehrlich em cultura primária.}

\subsubsection{Delineamento experimental}

Foi realizada a coleta de células tumorais, conforme descrito no item material e métodos, sendo a suspensão celular ajustada para $5 \times 10^{5}$ células $/ \mathrm{mL}$. Foram plaqueados $100 \mu \mathrm{L}$ desta suspensão celular por poço, em placas de 96 poços de poliestireno para cultura celular. As células foram mantidas por $1 \mathrm{~h} 30 \mathrm{~min}$ em estufa a $37^{\circ} \mathrm{C}$ e $5 \% \mathrm{CO}_{2}$, e após este período, tratadas com $10 \mu \mathrm{L}$ de solução de resíduo butanólico em meio RPMI nas concentrações de $10000 \mu \mathrm{g} / \mathrm{mL}, 5000 \mu \mathrm{g} / \mathrm{mL}, 1000$ $\mu \mathrm{g} / \mathrm{mL}, 100 \mu \mathrm{g} / \mathrm{mL}, 10 \mu \mathrm{g} / \mathrm{mL}, 1000 \mathrm{ng} / \mathrm{mL}$ e $100 \mathrm{ng} / \mathrm{mL}$, de forma que as concentrações finais em cada poço fossem de $909,09 \mu \mathrm{g} / \mathrm{mL}, 454,54 \mu \mathrm{g} / \mathrm{mL}, 90,90 \mu \mathrm{g} / \mathrm{mL}, 9,09 \mu \mathrm{g} / \mathrm{mL}$, 0,90 $\mu \mathrm{g} / \mathrm{mL}, 90,90 \mathrm{ng} / \mathrm{mL}$ e $9,09 \mathrm{ng} / \mathrm{mL}$, respectivamente. Para o controle, utilizou-se apenas meio RPMI. Para cada concentração do tratamento ou controle foram utilizados no mínimo 6 poços (sextuplicata). 


\subsubsection{Viabilidade celular}

O procedimento utilizado para a determinação da viabilidade celular, baseado na metabolização dos sais de tetrazolium (MTT) (MOSMANN, 1983), foi realizado 24 e 48 horas após o tratamento das células. Assim, 24 e 48 horas após o tratamento das células, utilizando-se placas de 96 poços, foram adicionados a cada poço $10 \mu \mathrm{L}$ de MTT $(5 \mathrm{mg} / \mathrm{mL})$, sendo as placas incubadas em estufa a $37^{\circ} \mathrm{C}$ e $5 \% \mathrm{CO}_{2}$ por 4 horas. Após a incubação, foram adicionados $100 \mu \mathrm{L}$ de solução de $0,04 \mathrm{~N}$ de $\mathrm{HCl}$ em isopropanol em cada poço, pipetando-se lentamente os poços para a dissolução dos cristais formados. Uma hora após este procedimento, as placas foram colocadas em espectofotômetro, sob comprimento de onda de $540 \mathrm{~nm}$.

\subsection{EXPERIMENTO VII - Efeito do resíduo butanólico sobre as fases do ciclo de células do tumor de Ehrlich em cultura primária, 48h após o tratamento}

\subsubsection{Delineamento experimental}

Foi realizada a coleta de células tumorais, conforme descrito no item material e métodos, sendo a suspensão celular ajustada para $5 \times 10^{5}$ células $/ \mathrm{mL}$. Para este procedimento, no entanto, foram utilizadas placas de 24 poços de polestireno para 
cultura celular, sendo plaqueado $1 \mathrm{~mL}$ desta suspensão celular por poço. As células foram mantidas por $1 \mathrm{~h} 30 \mathrm{~min}$ em estufa a $37^{\circ} \mathrm{C}$ e $5 \% \mathrm{CO}_{2}$, e após este período, as células foram tratadas com $100 \mu \mathrm{L}$ de solução de resíduo butanólico em meio RPMI nas concentrações de $10000 \mu \mathrm{g} / \mathrm{mL}, 5000 \mu \mathrm{g} / \mathrm{mL}, 1000 \mu \mathrm{g} / \mathrm{mL}, 100 \mu \mathrm{g} / \mathrm{mL}, 10 \mu \mathrm{g} / \mathrm{mL}, 1000$ $\mathrm{ng} / \mathrm{mL}$ e $100 \mathrm{ng} / \mathrm{mL}$, de forma que as concentrações finais em cada poço fossem de 909,09 $\mu \mathrm{g} / \mathrm{mL}, 454,54 \mu \mathrm{g} / \mathrm{mL}, 90,90 \mu \mathrm{g} / \mathrm{mL}, 9,09 \mu \mathrm{g} / \mathrm{mL}, 0,90 \mu \mathrm{g} / \mathrm{mL}, 90,90 \mathrm{ng} / \mathrm{mL}$ e 9,09 ng/mL, respectivamente. Para o controle, utilizou-se apenas meio RPMI. Para cada concentração do tratamento ou controle foram utilizados no mínimo 6 poços (sextuplicata).

\subsubsection{Ciclo celular}

Após 48 horas do tratamento, as placas foram centrifugadas a 1200 rpm por 8 minutos, sendo então descartado o sobrenadante. As células aderidas ao fundo do poço foram retiradas por meio da adição de $200 \mu \mathrm{L}$ de tripsina em cada poço. Foram adicionados então $500 \mu \mathrm{L}$ de meio RPMI contendo 10\% de SFB para a neutralização da tripsina. As células foram retiradas dos poços e a concentração celular correspondente a cada poço, determinada com o auxílio da câmara de Neubauer e azul de tripan. Em seguida $10^{6}$ células correspondentes a cada poço foram aliquotadas, centrifugadas a 1200 rpm por 5 minutos, desprezado o sobrenadante, sendo então ressuspensas em 1 $\mathrm{mL}$ de etanol $70 \%$, gelado. As amostras foram mantidas $\mathrm{a}-20^{\circ} \mathrm{C}$, por 1 semana, até o momento do uso. 
A etapa seguinte foi realizada de acordo com metodologia proposta por Spector, Goldman e Leinwand. (1998). Assim, as amostras de células em etanol foram centrifugadas a 9400 rpm por 5 minutos, sendo então desprezado o sobrenadante. As células foram ressuspensas em $1 \mathrm{~mL}$ de PBS 1x, novamente centrifugadas a $9400 \mathrm{rpm}$ por 5 minutos, sendo este procedimento repetido mais uma vez. Depois de desprezado o sobrenadante, as células foram ressuspensas em $200 \mu \mathrm{L}$ de suspensão constituída por $200 \mu \mathrm{g} / \mathrm{mL}$ de RNaseA e $20 \mu \mathrm{g} / \mathrm{mL}$ de solução de PI, em PBS, contendo $0,1 \%$ de triton $(\mathrm{v} / \mathrm{v})$. As células foram mantidas por 30 minutos em temperatura ambiente, ao abrigo da luz, sendo então transferidas para tubos de citometria para a leitura em citômetro de fluxo.

\subsubsection{Citômetro de fluxo}

Foi utilizado um citômetro de fluxo (Becton Dickinson Immunocytometry System, San Jose, CA, USA) conectado a um computador (Machintosh Apple, CA, USA). Foram adquiridos e analisados no mínimo 10000 eventos por meio de um software - Cell Quest Pro (Becton Dickinson Immunocytometry System, San Jose, CA, USA). As populações de interesse (células tumorais) foram analisadas por meio de gates, excluindo assim outros tipos celulares das amostras. Além disso, para todos es experimentos o aparelho foi calibrado com um tubo "branco" como controle de refringência.

As subpopulações celulares foram reconhecidas por meio das propriedades de FSC - Foward Scatter e SSC - Side Scatter que avaliam o tamanho e a complexidade 
interna, respectivamente. As fluorescências foram adquiridas em escala linear. A fluorescência do iodeto de propídeo foi detectada pelo leitor FL-2 (585ะ42nm).

Os dados referentes às fases do ciclo celular foram expressos em \% de células hipodiplóides, em fase G0/G1, S e G2 /M.

\subsection{Análise estatística}

Foi utilizado o teste $\mathrm{t}$ de Student para a comparação dos valores obtidos de experimentos com 2 grupos (para dados paramétricos, analisados pelo teste de Barlett) ou o teste $U$ de Mann-Whitney (para dados não paramétricos, analisados pelo teste de Barlett). Para a comparação dos valores obtidos de experimentos com 3 ou mais grupos, foi utilizada a ANOVA, seguida do pós teste de Tukey-Kramer.

Para a comparação dos pesos dos animais nos vários tempos de tratamento (experimento de toxicidade), foi utilizada a ANOVA de duas vias, seguido do teste $t$ de Student.

Para o tempo de sobrevida, foi realizada a curva de Kaplan-Meier e utilizado o teste de long-rank.

Foram consideradas significantes as análises que apresentaram um nível de significância $p<0,05$. Os resultados foram expressos como média \pm desvio padrão. 


\section{RESULTADOS}

\subsection{EXPERIMENTO I - Determinação do tempo de sobrevida dos animais portadores do tumor de Ehrlich na forma ascítica, tratados com o extrato etanólico, resíduo butanólico ou aquoso de $P$. paniculata}

Os animais tratados com o RB na concentração de 50 e $200 \mathrm{mg} / \mathrm{Kg}$ apresentaram tempo de sobrevida significantemente maior, em relação aos animais do grupo controle, conforme ilustrado na figura 3 . Os animais tratados com RA na concentração de $100 \mathrm{mg} / \mathrm{kg}$ apresentaram tempo de sobrevida significantemente maior, em relação aos animais pertencentes ao grupo controle, conforme ilustrado na figura 4. Não houve diferença entre os animais tratados com EE, nas três concentrações utilizadas, em relação aos animais pertencentes ao grupo controle, conforme ilustrado na figura 5. 
A

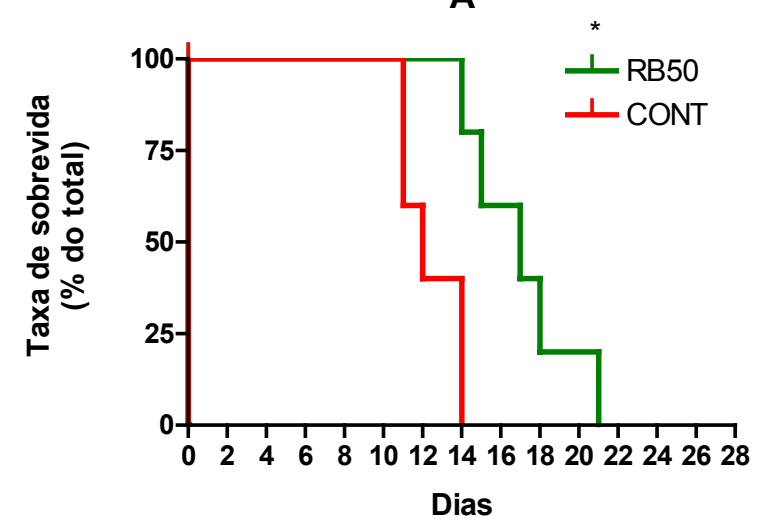

B

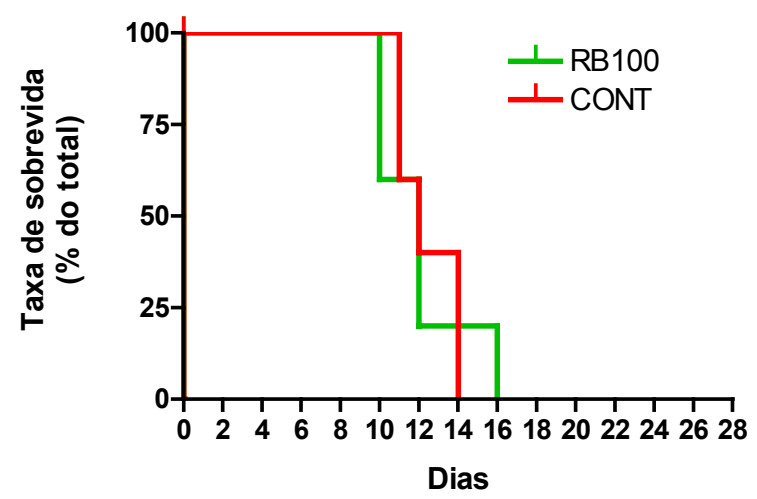

C

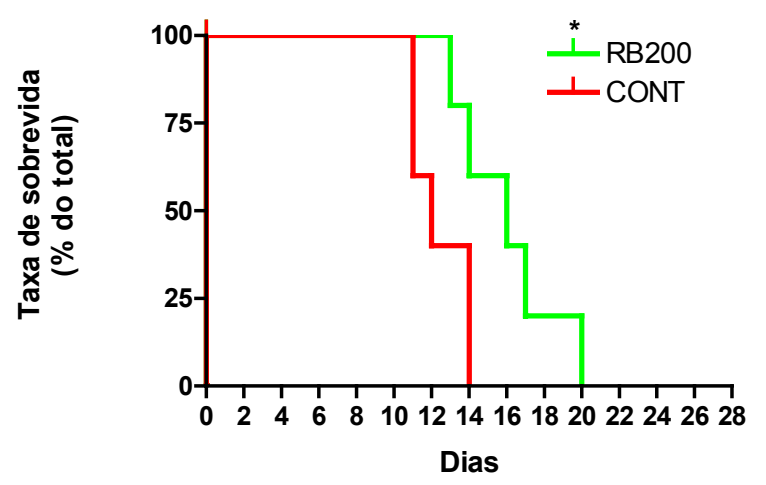

Figura 3 - Curvas de Kaplan-Meier de sobrevida de animais tratados com resíduo butanólico nas concentrações de 50 (RB50), 100 (RB100), 200 mg/Kg (RB200) ou com água (CONT), inoculados com $5 \times 10^{6}$ células tumorais, intraperitonealmente. A) $O$ grupo tratado com RB50 ( $n=5) \quad(p=0.0079$, teste de log-rank) apresentou uma maior sobrevida em relação ao grupo controle $(n=5)$. B) $O$ grupo tratado com RB100 $(n=5)$ não apresentou diferença na sobrevida, quando comparado ao grupo controle. C) O grupo tratado com RB200 $(n=5)(p=0.0389$, teste de log-rank) apresentou maior sobrevida em relação ao grupo controle. 
A

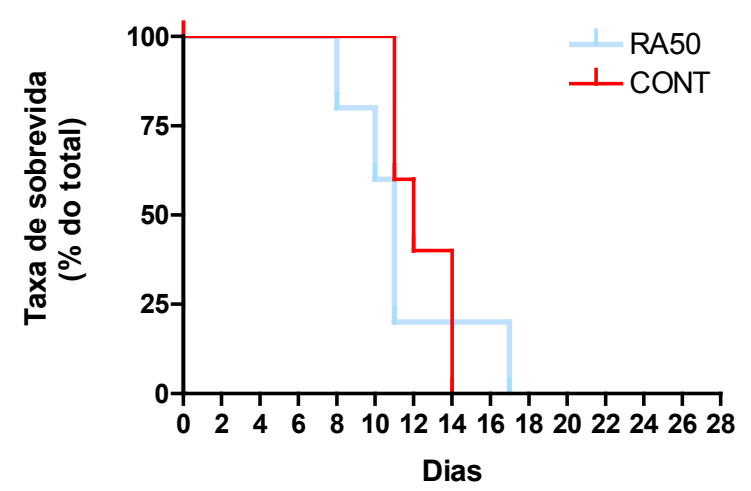

B

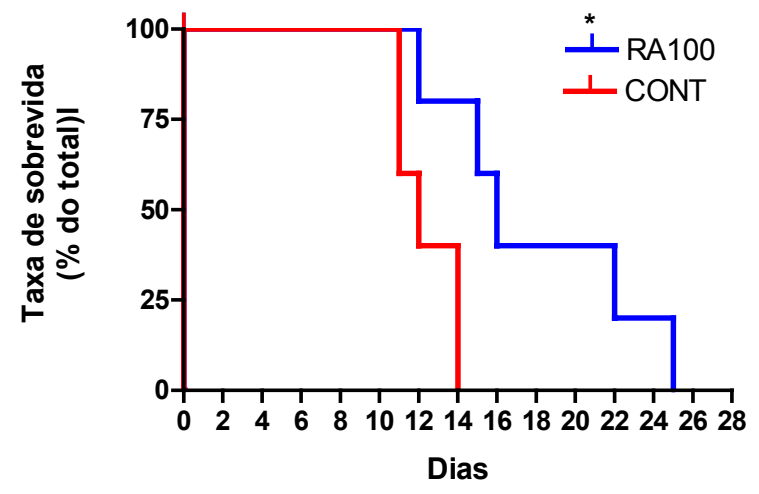

C

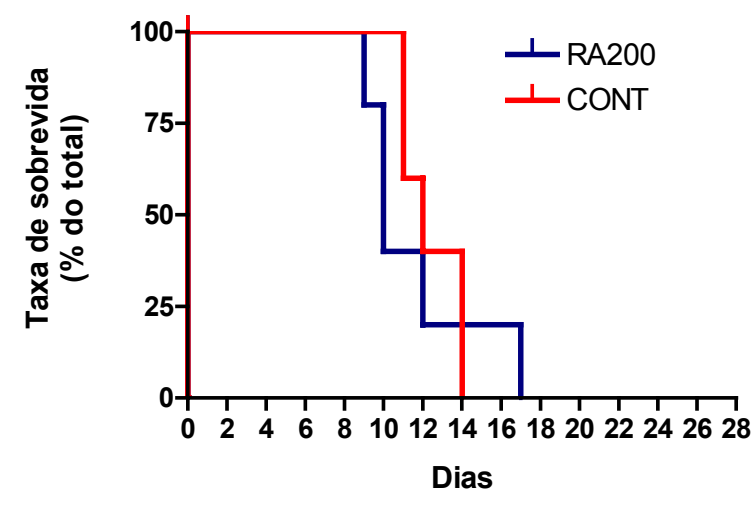

Figura 4 - Curvas de Kaplan-Meier de sobrevida de animais tratados com resíduo aquoso nas concentrações de 50 (RA50), 100 (RA100), 200 mg/Kg (RA200) ou com água (CONT), inoculados com $5 \times 10^{6}$ células tumorais, intraperitonealmente. A) $\mathrm{O}$ grupo tratado com RA50 $(n=5)$ não apresentou diferença na sobrevida, quando comparado ao grupo controle $(n=5)$. B) O grupo tratado com RA100 $(n=5)(p=0.0184$, log-rank) apresentou maior sobrevida em relação ao grupo controle e C) O grupo tratado com RA200 (n=5) não apresentou diferença na sobrevida, quando comparado ao grupo controle. 
A

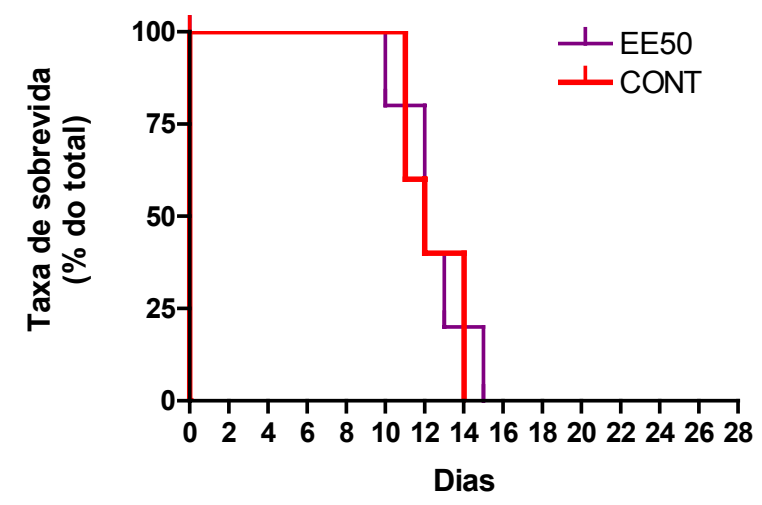

B

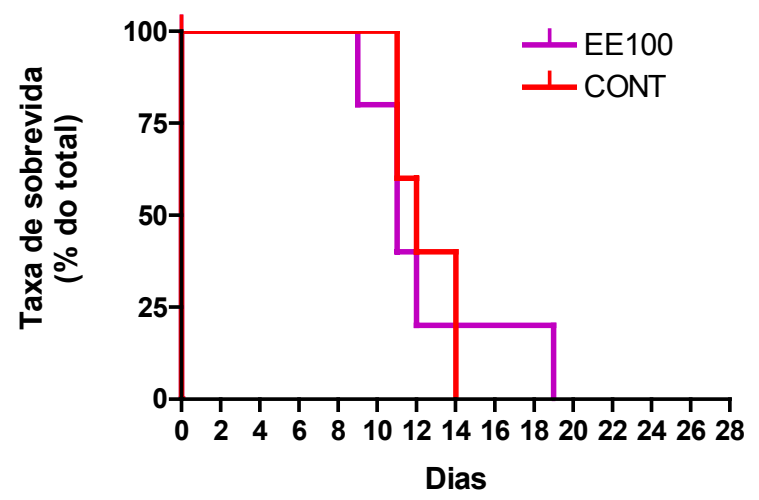

C

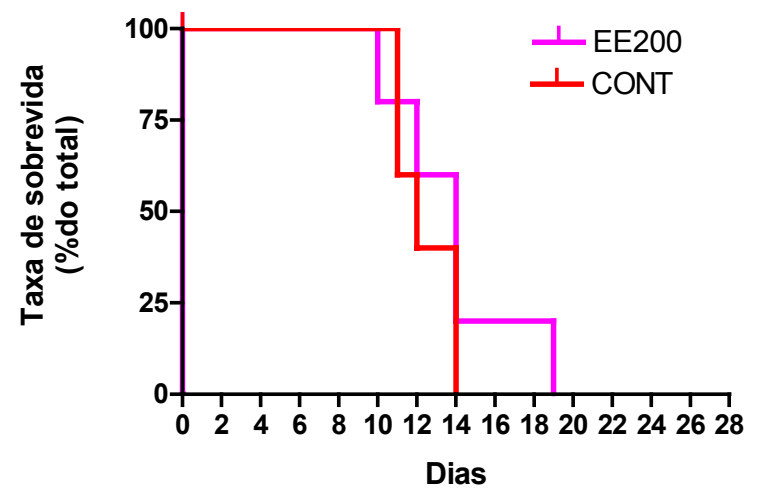

Figura 5 - Curvas de Kaplan-Meier de sobrevida de animais tratados com extrato etanólico nas concentrações de 50 (EE50), 100 (EE100), 200 mg/Kg (EE200) ou com água (CONT), inoculados com $5 \times 10^{6}$ células tumorais, intraperitonealmente. A, B e C) Os grupos tratados com EE50 $(n=5)$, EE100 $(n=5)$ e EE200 $(n=5)$ não apresentaram diferença na sobrevida, quando comparados ao grupo controle $(n=5)$. 
5.2 EXPERIMENTO II - Avaliação dos efeitos do resíduo butanólico sobre alguns parâmetros da toxicidade hepática e renal

\begin{abstract}
A atividade sérica da enzima $\gamma$-GT foi significantemente menor nos animais tratados com RB200 em relação aos animais pertencentes ao grupo controle, conforme ilustra a figura 6A. Não houve diferença significante nas atividades séricas das enzimas AST, ALT e nas concentrações séricas de uréia e de creatinina de animais tratados com RB200 em relação aos animais pertencentes ao grupo controle, conforme ilustram as figuras $6 B, C, D$ e $E$, respectivamente.
\end{abstract}


A

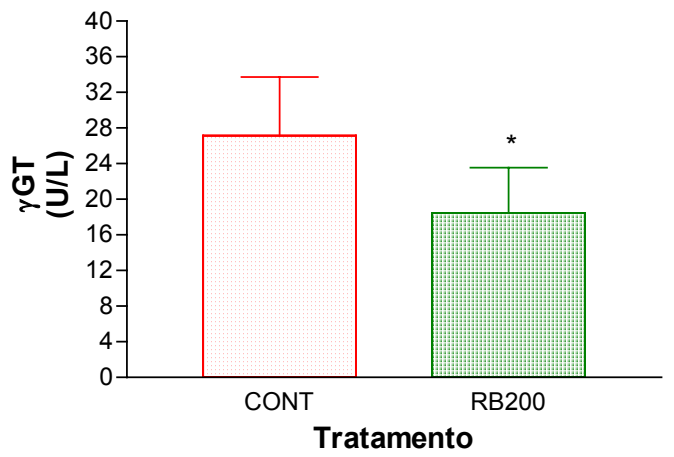

C

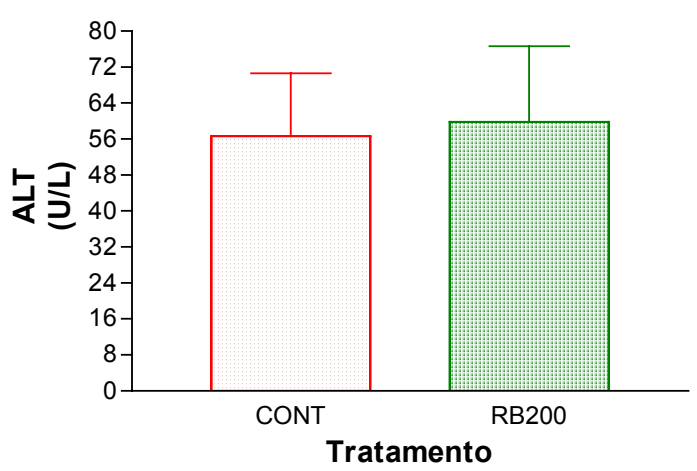

E

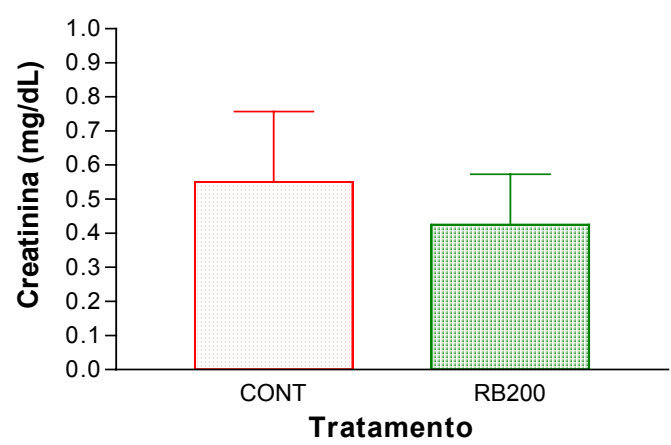

B

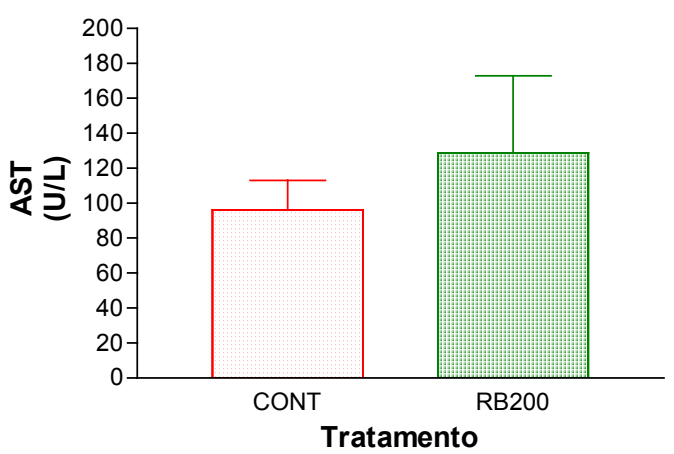

D

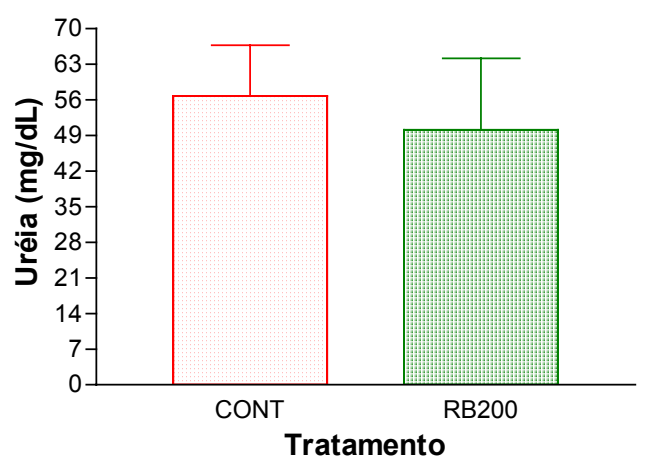

Figura 6- Atividades das enzimas $\gamma$-GT, AST, ALT e concentrações das enzimas uréia e creatinina no soro de animais tratados com $200 \mathrm{mg} / \mathrm{Kg}$ de resíduo butanólico (RB200) ou com água (CONT). A) A atividade de $\gamma$-GT foi significantemente menor nos animais tratados com RB200 ( $n=9)$ em relação ao grupo controle $(n=8)\left({ }^{*} p<0.05\right.$, teste $t$ de Student). B, C, D e E) Os animais tratados com RB200 não apresentaram diferença significante nas atividades de ALT $(n=7)$, AST $(n=7)$ e nas concentrações de uréia $(n=9)$ e creatinina $(n=8)$, em relação ao grupo controle $(n=6)$. 
O ganho de peso dos animais pertencentes ao grupo RB200 foi significantemente menor em relação aos animais pertencentes ao grupo controle nos dias 13 e 15 do período experimental, conforme ilustra a figura 7 .

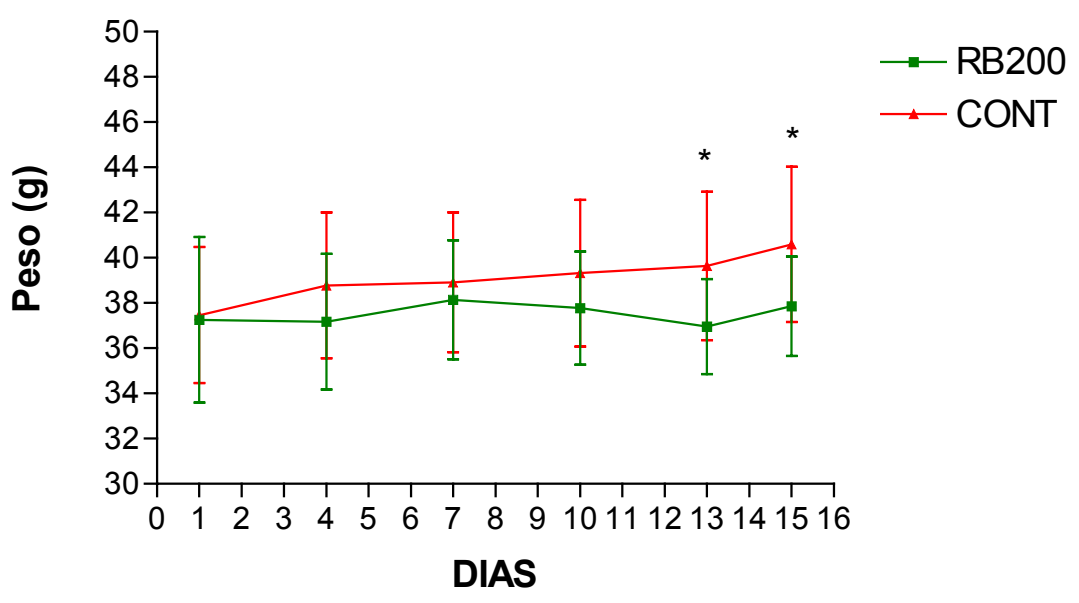

Figura 7 - O ganho de peso dos animais tratados com $200 \mathrm{mg} / \mathrm{Kg}$ de resíduo butanólico (RB200) $(n=10)$ foi significantemente menor ( ${ }^{*} p<0.05$, teste $t$ de Student) nos dias 13 e 15 , em relação ao grupo controle $(n=10)$.

No exame histopatológico, tanto os rins como o baço, dos animais pertencentes ao grupo controle e tratados com RB200, apresentaram-se morfologicamente preservados, conforme ilustram as figuras 8 e 9 . O fígado apresentou algumas áreas dispersas de degeneração vacuolar leve a moderada, tanto em animais tratados com RB200 quanto em animais pertencentes ao grupo controle, conforme ilustra a figura 10. 

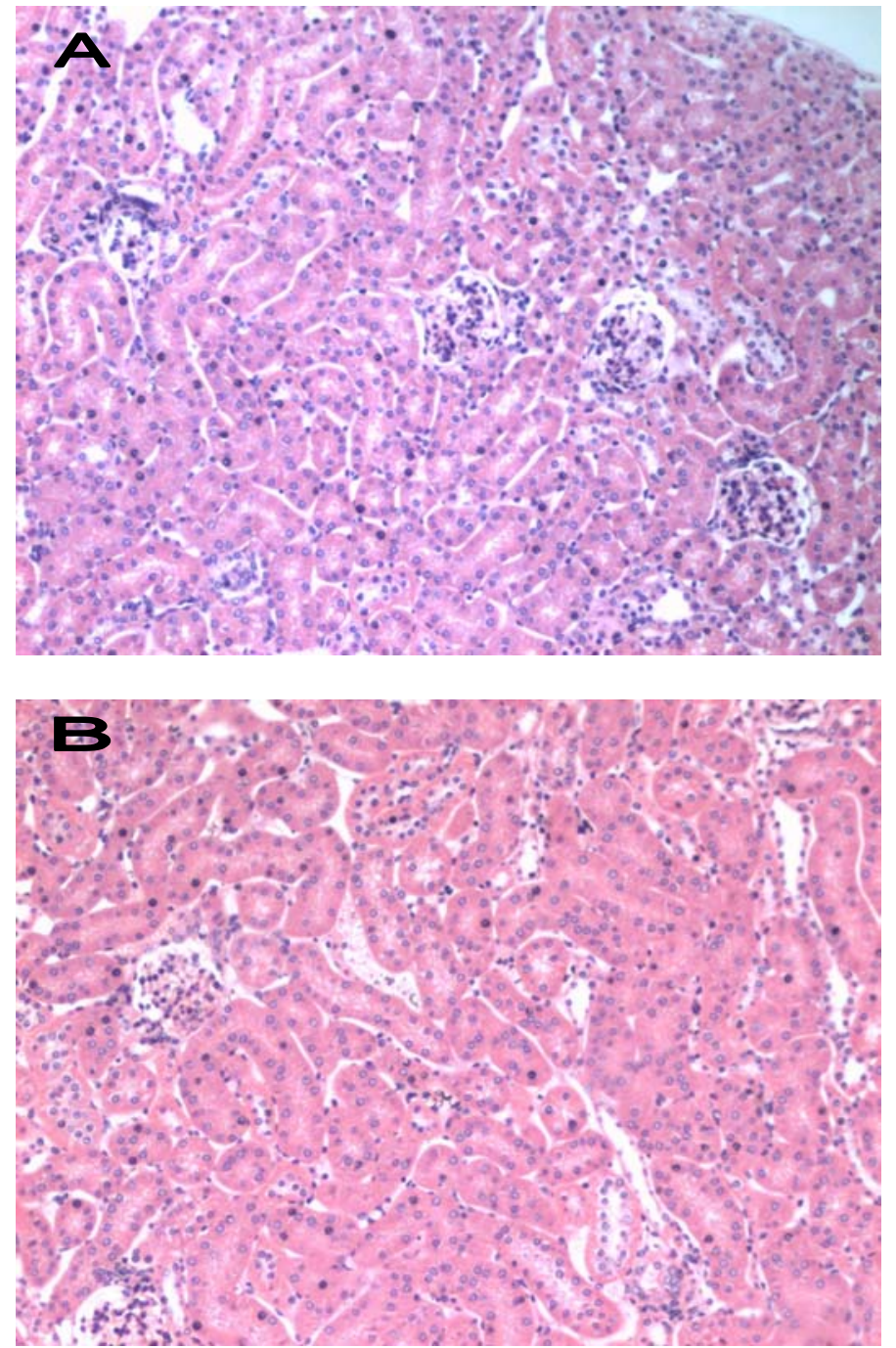

Figura 8 - A) Fotomicrografia de rim de animal pertencente ao grupo controle, H\&E, objetiva 10x. Não se observaram alterações dignas de nota na região cortical (representado) e medular (não representado). B) Fotomicrografia de rim de animal tratado com $200 \mathrm{mg} / \mathrm{Kg}$ de resíduo butanólico, H\&E, objetiva 10x. Não se observaram alterações dignas de nota na região cortical (representado) e medular (não representado). 

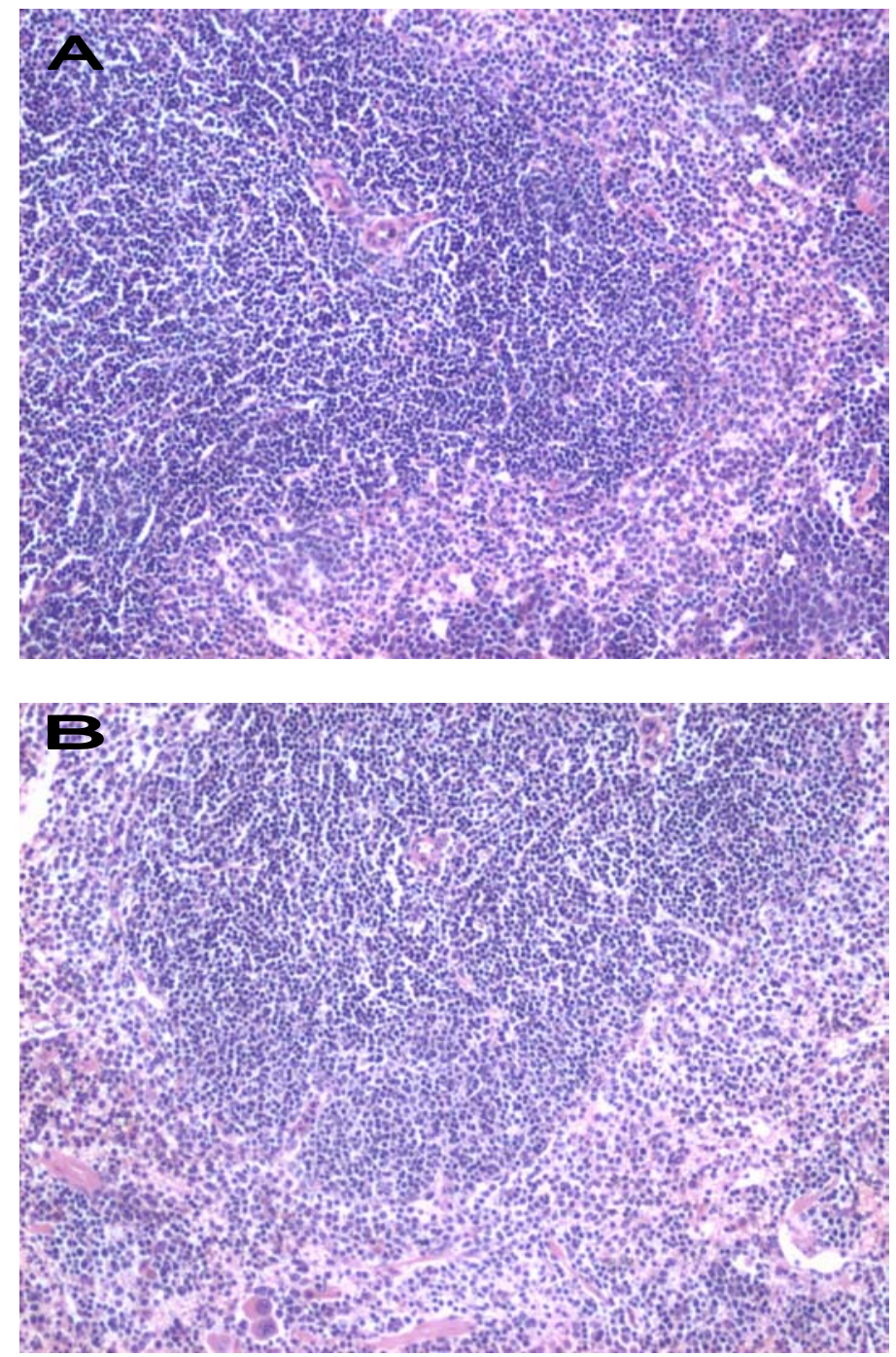

Figura 9 - A) Fotomicrografia de baço de animal pertencente ao grupo controle; não se observam alterações dignas de nota na polpa branca, área constituída por folículos linfóides, e bainha linfóide peri-arteriolar, $\mathrm{H} \& \mathrm{E}$, objetiva 10x. B) Fotomicrografia de baço de animal tratado com $200 \mathrm{mg} / \mathrm{Kg}$ de resíduo butanólico; não se observam alterações dignas de nota na polpa branca, área constituída por folículos linfóides, e bainha linfóide peri-arteriolar, $H \& E$, objetiva 10x. 

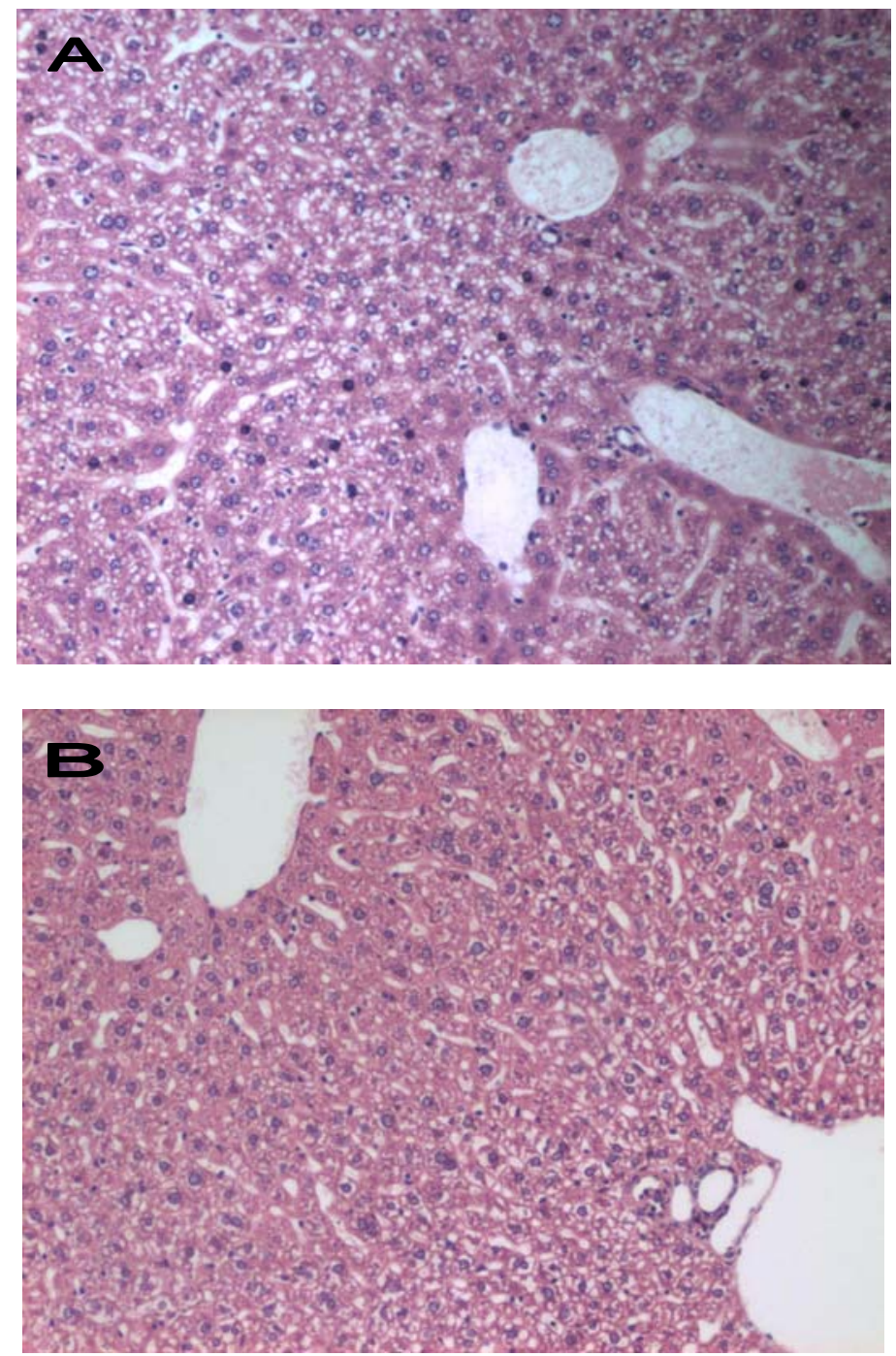

Figura 10 -A) Fotomicrografia de fígado mostrando degeneração vacuolar moderada em animal pertencente ao grupo controle, $\mathrm{H} \& \mathrm{E}$, objetiva 10x. B) Fotomicrografia de fígado mostrando degeneração vacuolar moderada em animal tratado com $200 \mathrm{mg} / \mathrm{Kg}$ de resíduo butanólico, H\&E, objetiva 10x. 


\subsection{EXPERIMENTO III - Efeito do resíduo butanólico sobre o crescimento do tumor de Ehrlich, forma ascítica}

Não houve diferença estatisticamente significante quanto ao volume do fluído ascítico, número de células $/ \mathrm{mL}$ e número de células tumorais presentes no fluído ascítico, entre o grupo tratado com $50 \mathrm{mg} / \mathrm{Kg}$ de RB e o grupo controle, conforme mostra a tabela 1 e ilustram as figuras 11,12 e 13, respectivamente.

Tabela 1- Volume do fluído ascítico, número de células $/ \mathrm{mL}$ e número total de células tumorais de animais inoculados intraperitonealmente com $5,0 \times 10^{6}$ células do tumor de Ehrlich, e tratados por 14 dias com $50 \mathrm{mg} / \mathrm{Kg}$ resíduo butanólico solúvel (RB50) ou com água (CONT).

\begin{tabular}{|c|c|c|c|c|}
\hline Tratamento & $\mathbf{n}$ & Volume (mL) & $\begin{array}{l}\text { n. cels/mL } \\
\left(\times 10^{8}\right)\end{array}$ & $\begin{array}{c}\text { Número de } \\
\text { células totais } \\
\left(\times 10^{8}\right)\end{array}$ \\
\hline Cont & 6 & $7,01 \pm 2,06$ & $0,74 \pm 0,13$ & $5,04 \pm 1,18$ \\
\hline RB50 & 6 & $5,30 \pm 2,52$ & $0,76 \pm 0,24$ & $4,20 \pm 2,617$ \\
\hline
\end{tabular}

$\mathrm{n}=$ número de animais.

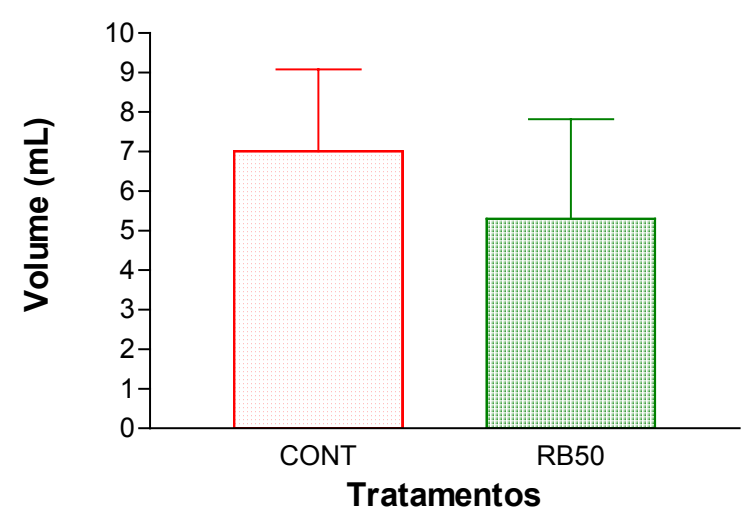

Figura 11 - Volume do fluído ascítico $(\mathrm{mL})$ de animais inoculados intraperitonealmente com 5,0 $\times 10^{6}$ células do tumor de Ehrlich, e tratados por 14 dias com $50 \mathrm{mg} / \mathrm{Kg}$ de resíduo butanólico $(\operatorname{RB} 50)(n=6)$ ou com água $(C O N T)(n=6)$. 


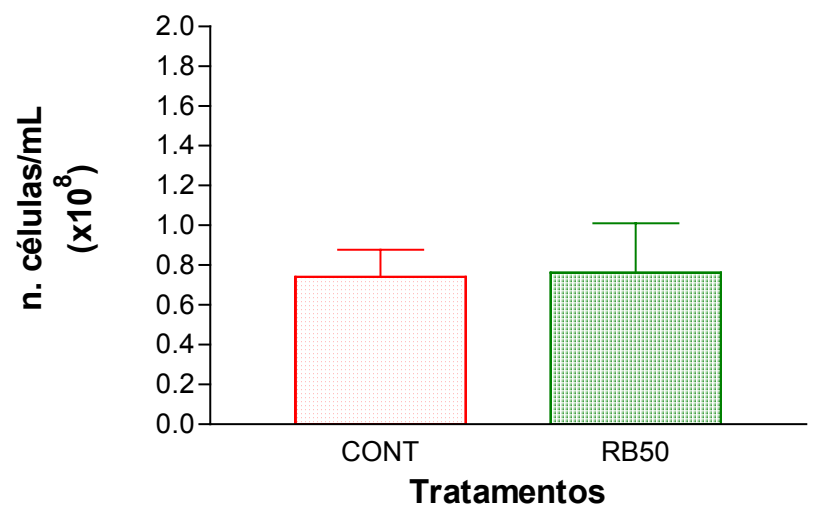

Figura 12 - Número células tumorais $/ \mathrm{mL}\left(\times 10^{8}\right)$ de animais inoculados intraperitonealmente com $5,0 \times 10^{6}$ células do tumor de Ehrlich, e tratados por 14 dias com $50 \mathrm{mg} / \mathrm{Kg}$ de resíduo butanólico (RB50) $(n=6)$ ou com água (CONT) $(n=6)$.

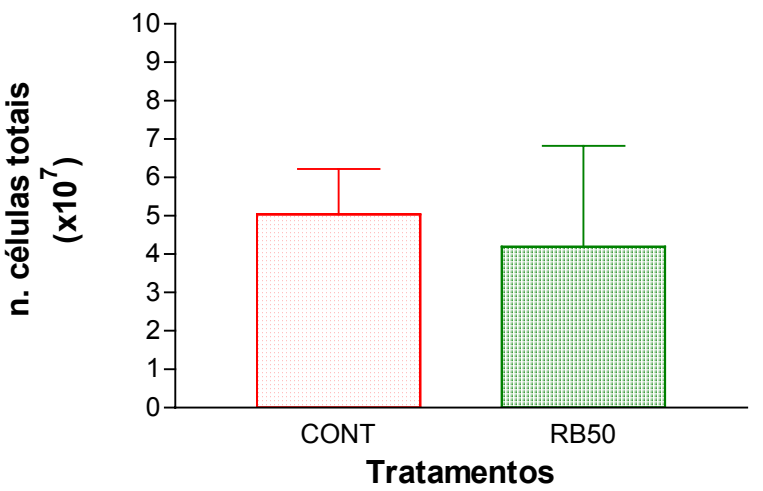

Figura 13 - Número total de células tumorais de animais inoculados intraperitonealmente com $5,0 \times 10^{6}$ células do tumor de Ehrlich, e tratados por 14 dias com $50 \mathrm{mg} / \mathrm{Kg}$ de resíduo butanólico $(\mathrm{RB} 50)(n=6)$ ou com água $(\mathrm{CONT})(n=6)$. 


\subsection{EXPERIMENTO IV - Efeito do resíduo butanólico sobre alguns parâmetros da atividade macrofágica}

A figura 14 ilustra um citograma de células do peritôneo de um animal representativo, pertencente ao grupo controle; a região R1corresponde à população de macrófagos analisada.

O burst oxidativo induzido por $S$. aureus foi significantemente menor no grupo tratado com $50 \mathrm{mg} / \mathrm{Kg}$ de $\mathrm{RB}$ em relação ao grupo controle, conforme mostra a tabela 2 e ilustra a figura 15; não houve diferença estatisticamente significante no burst oxidativo ativado por PMA ou espontâneo, entre o grupo tratado com $50 \mathrm{mg} / \mathrm{Kg}$ de RB e o grupo controle, conforme mostra a tabela 2 e ilustram as figuras 16 e 17, respectivamente.

Não houve diferença estatisticamente significante quanto à porcentagem (\%) de macrófagos que realizaram fagocitose, nem quanto à intensidade de fagocitose (correspondente ao número de bactérias internalizadas), conforme mostra a tabela 3 e ilustram as figuras 18 e 19, respectivamente, entre o grupo tratado com $50 \mathrm{mg} / \mathrm{Kg}$ de $\mathrm{RB}$ em relação ao grupo controle. 


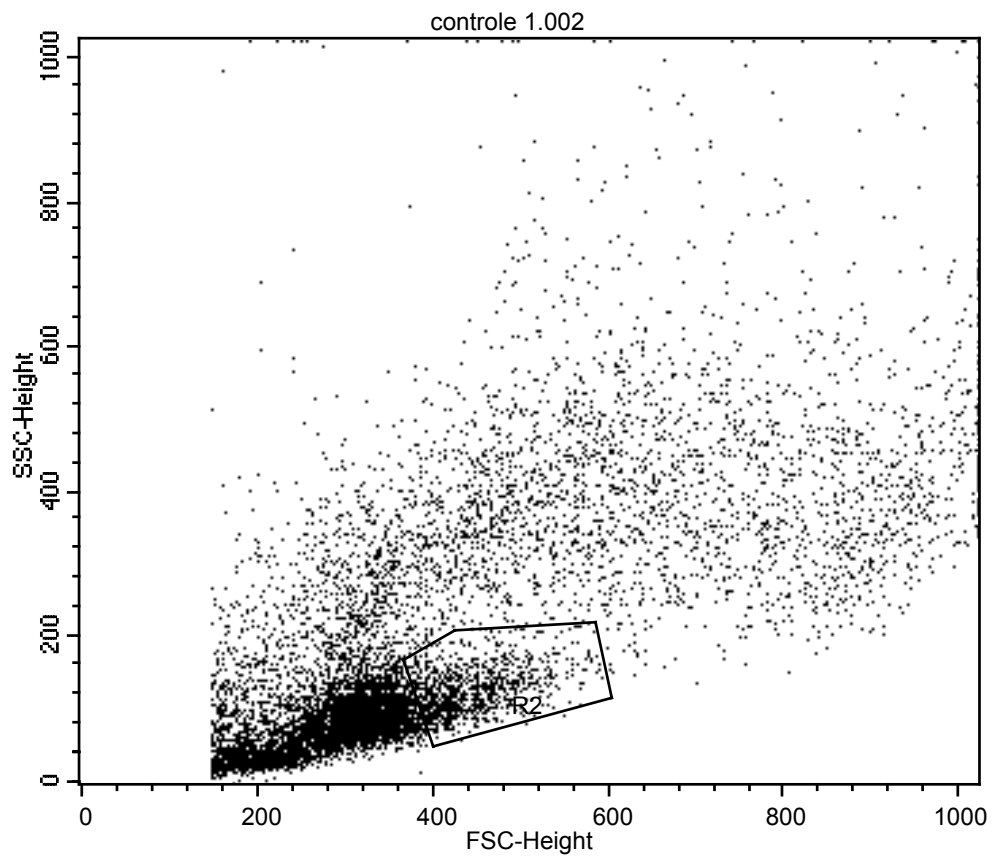

Figura 14 - Citograma de células peritoneais, 24 horas após a inoculação intraperitoneal de 5,0 x $10^{6}$ células tumorais, ilustrando uma população R1 analisada e composta por macrófagos.

Tabela 2 - Burst oxidativo ativado por S. aureus (S.aureus), ativado por PMA (PMA) ou espontâneo (DCFH) de macrófagos peritoneais, 24 horas após a inoculação de $5 \mathrm{x}$ $10^{6}$ células tumorais, intraperitonealmente, de animais tratados com $50 \mathrm{mg} / \mathrm{Kg}$ de resíduo butanólico (RB50) ou com água (CONT),

\begin{tabular}{ccccc}
\hline Tratamento & n & S. aureus & PMA & DCFH \\
\hline CONT & 6 & $7,05 \pm 3,36$ & $7,45 \pm 3,36$ & $8,24 \pm 2,25$ \\
RB50 & 7 & $4,81 \pm 1,35^{*}$ & $5,30 \pm 1,89$ & $5,77 \pm 2,38$ \\
\hline
\end{tabular}

\footnotetext{
* teste t de Student

$\mathrm{n}=$ número de animais
} 


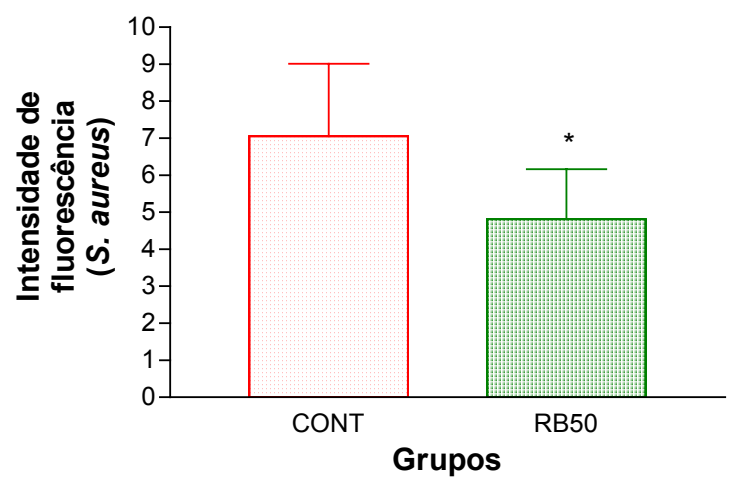

Figura 15 - Burst oxidativo ativado por $S$. aureus de macrófagos peritoneais, 24 horas após inoculação de $5 \times 10^{6}$ células tumorais, intraperitonealmente, de animais tratados com $50 \mathrm{mg} / \mathrm{Kg}$ de resíduo butanólico (RB50) $(n=7)$ ou com água (CONT) $(n=6)$. ${ }^{*} p<0.05$, teste $t$ de Student.

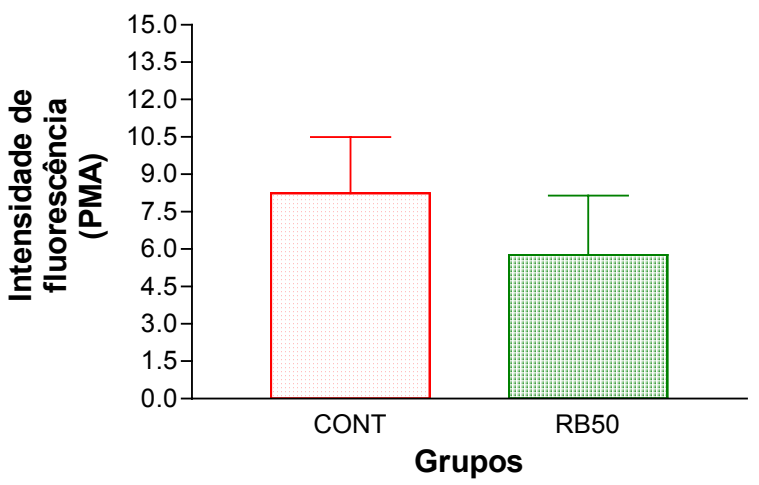

Figura 16 -Burst oxidativo ativado por PMA de macrófagos peritoneais, 24 horas após inoculação de $5 \times 10^{6}$ células tumorais, intraperitonealmente, de animais tratados com $50 \mathrm{mg} / \mathrm{Kg}$ de resíduo butanólico $(\mathrm{RB} 50)(\mathrm{n}=7)$ ou com água (CONT) $(n=6)$.

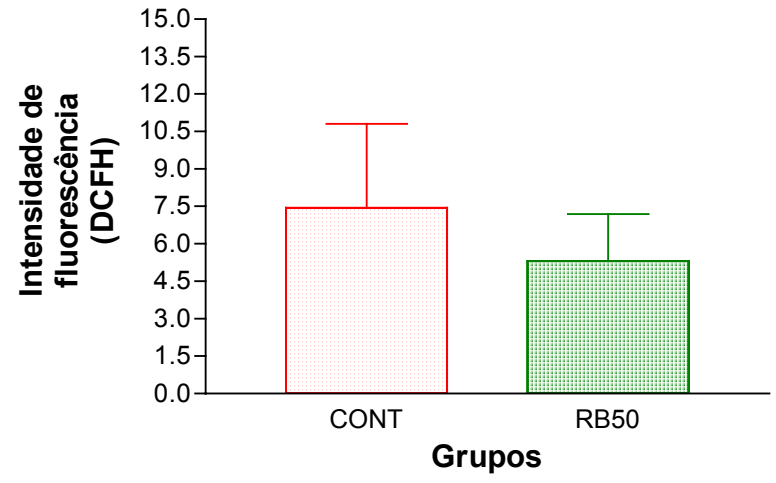

Figura 17 - Burst oxidativo espontâneo de macrófagos peritoneais, 24 horas após inoculação de $5 \times 10^{6}$ células tumorais, intraperitonealmente, de animais tratados com $50 \mathrm{mg} / \mathrm{Kg}$ de resíduo butanólico $(\mathrm{RB} 50)(n=7)$ ou com água $(\mathrm{CONT})(n=6)$. 
Tabela 3 - Porcentagem (\%) e intensidade de fagocitose de macrófagos peritoneais, 24 horas após a inoculação de $5 \times 10^{6}$ células tumorais, intraperitonealmente, de animais tratados com $50 \mathrm{mg} / \mathrm{Kg}$ de resíduo butanólico (RB50) ou com água (CONT).

\begin{tabular}{cccc}
\hline Tratamento & $\mathbf{n}$ & \% fagocitose & Intensidade de fagocitose \\
\hline CONT & 6 & $25,35 \pm 8,94$ & $2,26 \pm 0,37$ \\
RB50 & 7 & $29,43 \pm 6,14$ & $2,48 \pm 0,24$ \\
\hline
\end{tabular}

$\mathrm{n}=$ número de animais

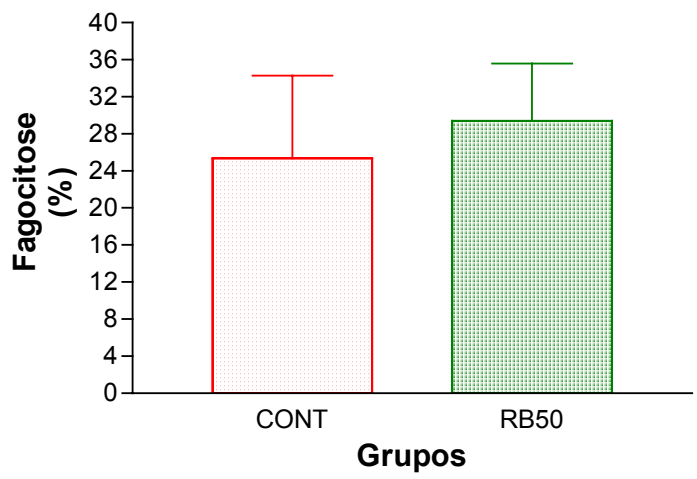

Figura 18 - Porcentagem (\%) de macrófagos peritoneais que realizaram fagocitose, 24 horas após a inoculação de $5 \times 10^{6}$ células tumorais, intraperitonealmente, de animais tratados com $50 \mathrm{mg} / \mathrm{Kg}$ de resíduo butanólico (RB50) ( $\mathrm{n}=7$ ) ou com água (CONT) $(n=6)$.

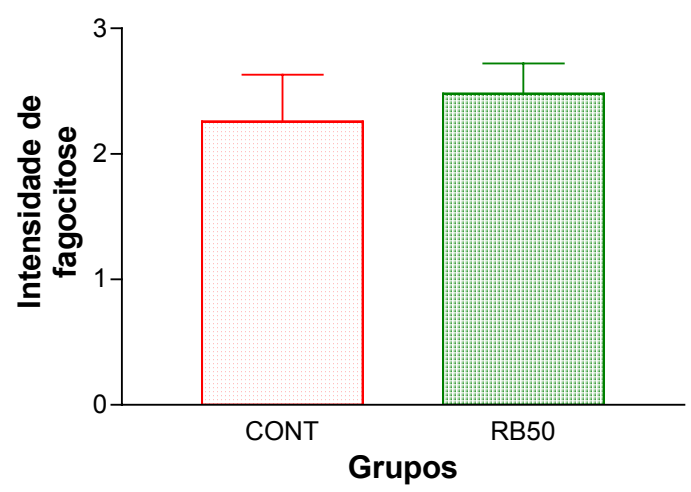

Figura 19 - Intensidade de fagocitose de macrófagos peritoneais, 24 horas após a inoculação de $5 \times 10^{6}$ células tumorais, intraperitonealmente, de animais tratados com $50 \mathrm{mg} / \mathrm{Kg}$ de resíduo butanólico $(\mathrm{RB} 50)(\mathrm{n}=7)$ ou com água (CONT) $(n=6)$. 


\subsection{EXPERIMENTO V - Efeito do resíduo butanólico sobre o crescimento do tumor de Ehrlich, forma sólida.}

\subsubsection{Espessura dos coxins}

Não houve diferença na evolução da espessura dos coxins dos animais tratados com o RB nas concentrações de 50, 100 e 200mg/Kg em relação aos animais pertencentes ao grupo controle, conforme ilustra a figura 20.

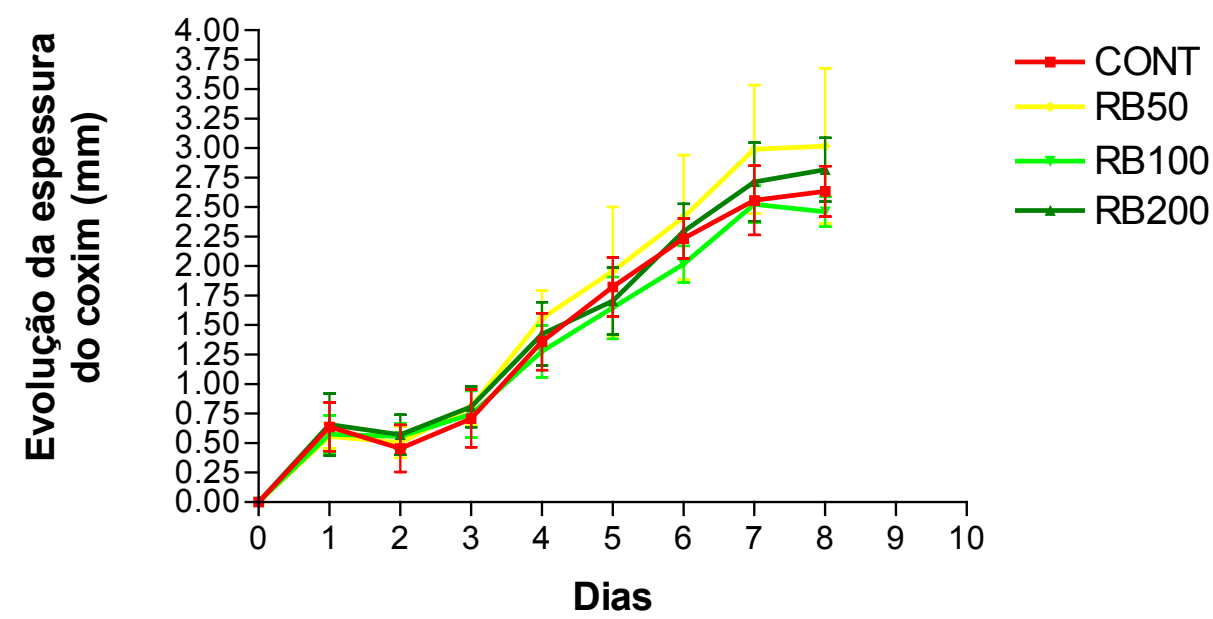

Figura 20 - Evolução da espessura do coxim, no período de 8 dias, de animais inoculados com $2,5 \times 10^{6}$ células tumorais, tratados com resíduo butanólico nas concentrações de $50 \mathrm{mg} / \mathrm{Kg}$ (RB50) (n=9), 100mg/Kg (RB100) $(\mathrm{n}=8), 200 \mathrm{mg} / \mathrm{Kg}(\mathrm{RB} 200)(\mathrm{n}=8)$ ou com água (CONT) $(n=9)$. 


\subsubsection{Exame histopatológico}

Tanto nos animais pertencentes aos grupos tratados com as diferentes concentrações de RB quanto nos animais pertencentes ao grupo controle, observou-se extensas áreas de necrose superficiais e profundas na área tumoral. As células tumorais inoculadas no coxim plantar apresentaram intensa proliferação local, invadindo e destruindo estruturas como tecido conjuntivo, musculatura e anexos. O tecido neoplásico apresentou-se como massa sólida, com alta celularidade, tomando grandes porções da derme superficial e profunda. As células tumorais apresentaram intenso pleomorfismo, com núcleos grandes, nucléolos evidentes e freqüentes figuras de mitose aberrantes.

As fotomicrografias dos cortes histológicos dos coxins plantares corados em H\&E e das células positivas para o PCNA, por imunoistoquímica, tanto dos animais tratados com as diferentes concentrações do RB quanto dos animais controles, estão representados nas figuras 21 e 22 , respectivamente. 

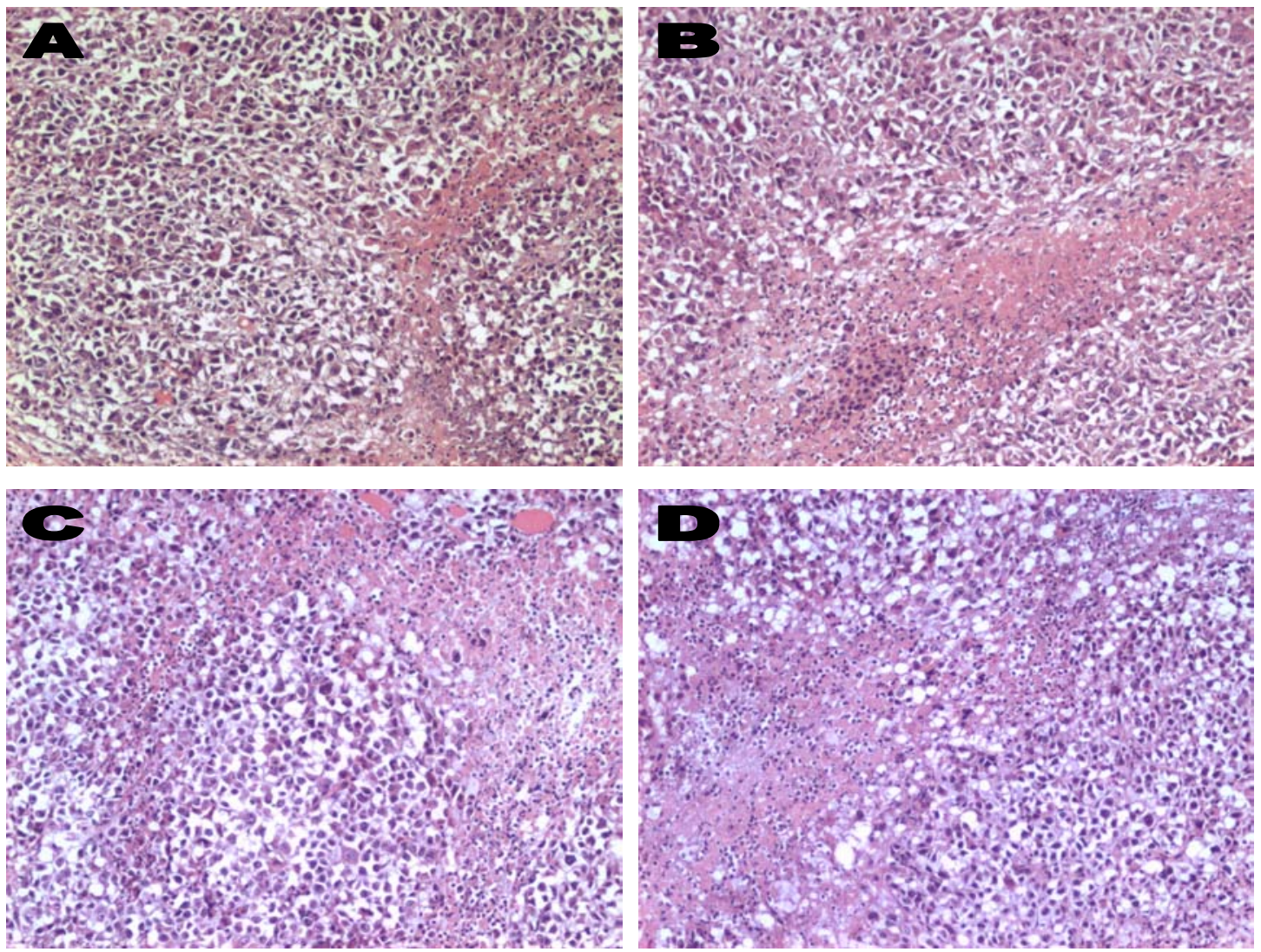

Figura 21 - Fotomicrografias de cortes histológicos de coxins plantares de animais inoculados há 8 dias com $2,5 \times 10^{6}$ células tumorais, pertencentes aos grupos A) Controle B) Tratados com $50 \mathrm{mg} / \mathrm{Kg}$ de resíduo butanólico C) Tratados com $100 \mathrm{mg} / \mathrm{Kg}$ de resíduo butanólico D) Tratados com $200 \mathrm{mg} / \mathrm{Kg}$ de resíduo butanólico. Observamse extensas áreas de necrose e alta celularidade em todos os animais, $\mathrm{H} \& \mathrm{E}$, objetiva 10x. 

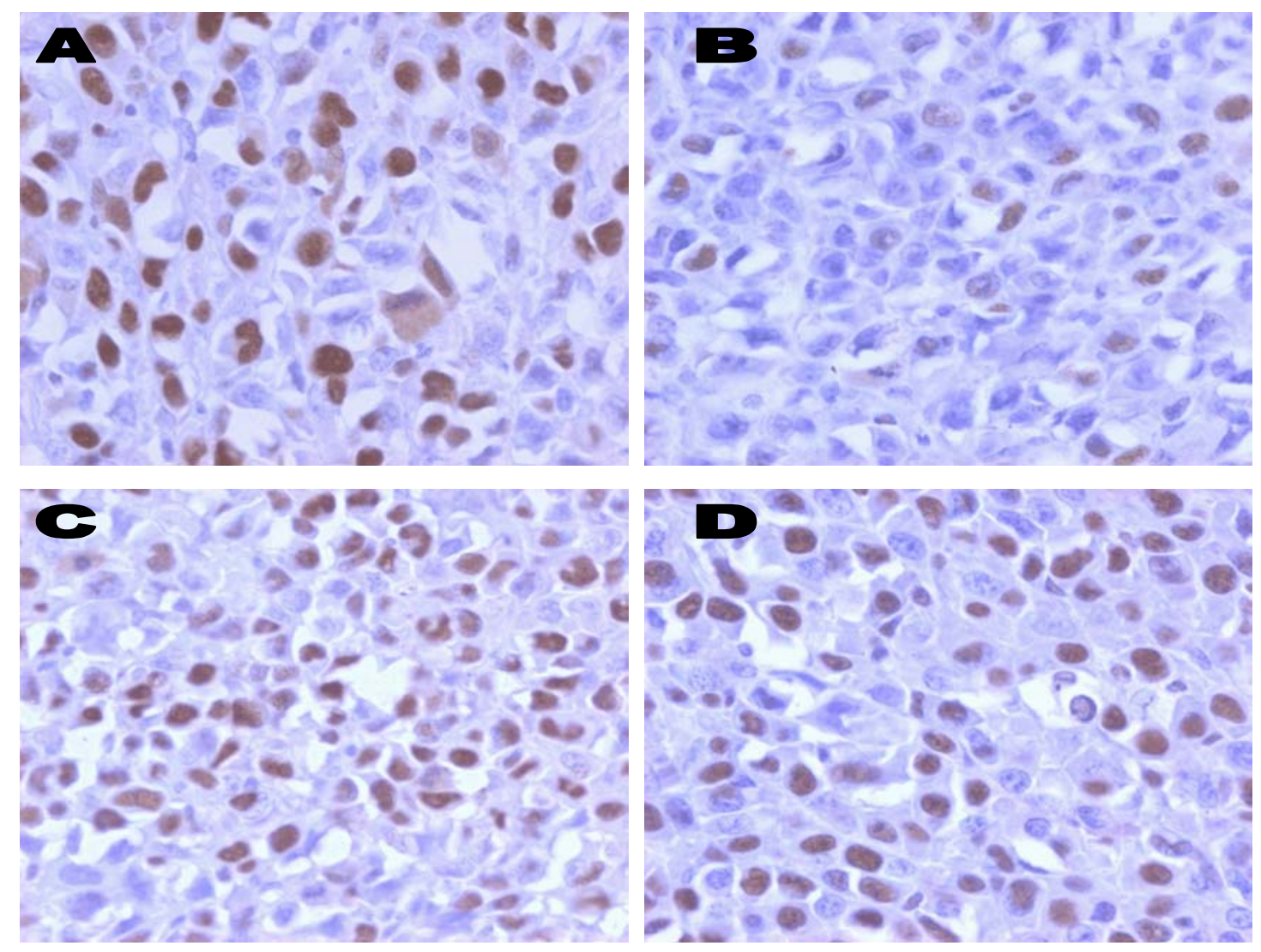

Figura 22 - Fotomicrografias de cortes histológicos de coxins plantares, mostrando células positivas para o PCNA, de animais inoculados há 8 dias com $2,5 \times 10^{6}$ células tumorais, pertencentes aos grupos A) Controle B) Tratados com $50 \mathrm{mg} / \mathrm{Kg}$ de resíduo butanólico C) Tratados com $100 \mathrm{mg} / \mathrm{Kg}$ de resíduo butanólico D) Tratados com $200 \mathrm{mg} / \mathrm{Kg}$ de resíduo butanólico. Estreptavidina-biotina-peroxidasediaminobenzidina, objetiva 20x. 
5.5.3 Porcentagem de necrose na área tumoral e quantificação da proliferação celular

A porcentagem de células tumorais positivas para o PCNA foi significantemente menor no grupo tratado com $50 \mathrm{mg} / \mathrm{Kg}$ de $\mathrm{RB}$ em relação ao grupo controle, conforme ilustra a figura 23 e a tabela 4. Os demais grupos não apresentaram diferença em relação ao grupo controle, conforme ilustra a figura 23 e a tabela 4. Não houve diferença quanto à porcentagem da área de necrose em meio à massa tumoral entre os animais tratados com RB, nas diferentes concentrações, e os animais pertencentes ao grupo controle, conforme ilustra a figura 24 e a tabela 4.

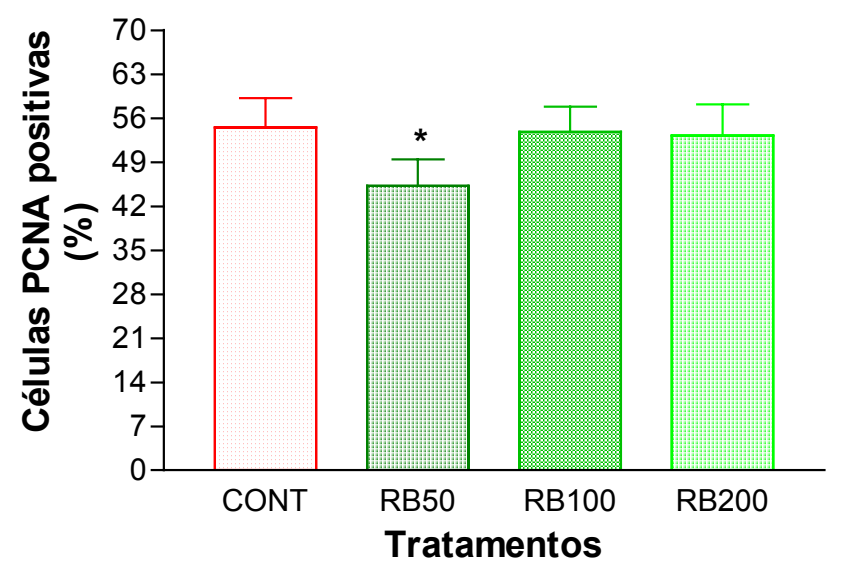

Figura 23 - Células tumorais positivas para o PCNA (\%) de coxim plantar de camundongos inoculados há 8 dias com $2,5 \times 10^{6}$ células tumorais, tratados com resíduo butanólico nas concentrações de $50 \mathrm{mg} / \mathrm{Kg}(\mathrm{RB} 50)(\mathrm{n}=6), 100 \mathrm{mg} / \mathrm{Kg}(\mathrm{RB} 100)(\mathrm{n}=5)$, $200 \mathrm{mg} / \mathrm{Kg}(\mathrm{RB} 200)(\mathrm{n}=5)$ ou com água $(\mathrm{CONT})(\mathrm{n}=6)$. ${ }^{*} p<0.05$, ANOVA seguida de Tukey-Kramer. 


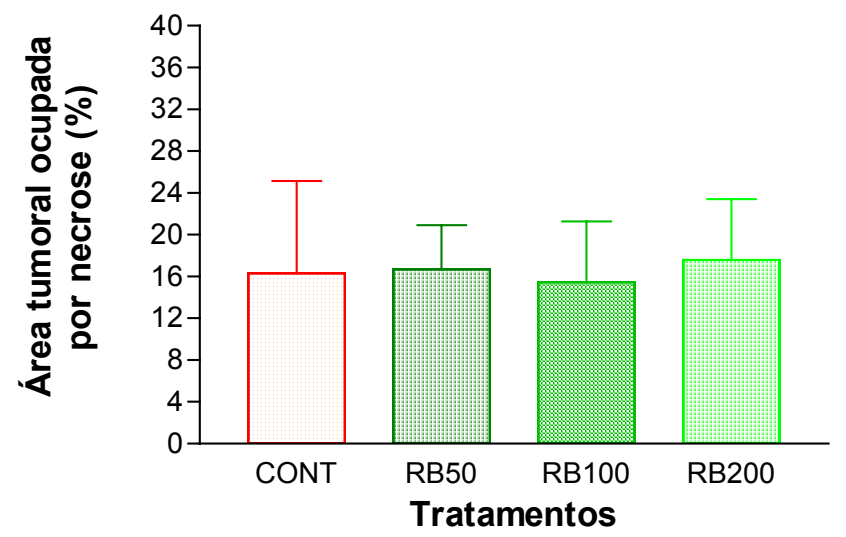

Figura 24 - Área tumoral ocupada por necrose (\%) de coxim plantar de camundongos inoculados há 8 dias com $2,5 \times 10^{6}$ células tumorais, tratados com resíduo butanólico nas concentrações de $50 \mathrm{mg} / \mathrm{Kg}$ (RB50) ( $\mathrm{n=6}), 100 \mathrm{mg} / \mathrm{Kg}$ (RB100) $(\mathrm{n}=5), 200 \mathrm{mg} / \mathrm{Kg}(\mathrm{RB} 200)(\mathrm{n}=5)$ ou com água (CONT) $(\mathrm{n}=6)$.

Tabela 4 - Células tumorais positivas para o PCNA (\%) e área tumoral ocupada por necrose (\%) de camundongos inoculados há 8 dias com 2,5 x 106 células tumorais, tratados com resíduo butanólico nas concentrações de $50 \mathrm{mg} / \mathrm{Kg}$ (RB50) ( $\mathrm{n}=6), 100 \mathrm{mg} / \mathrm{Kg}$ (RB100) $(n=5), 200 \mathrm{mg} / \mathrm{Kg}(\mathrm{RB} 200)(\mathrm{n}=5)$ ou com água (CONT) $(\mathrm{n}=6)$.

\begin{tabular}{cccc}
\hline Tratamento & $\mathbf{n}$ & $\begin{array}{c}\text { Células PCNA } \\
\text { positivas (\%) }\end{array}$ & $\begin{array}{c}\text { Área tumoral ocupada por } \\
\text { necrose (\%) }\end{array}$ \\
\hline CONT & 6 & $54,53 \pm 4,66$ & $16,30 \pm 8,85$ \\
RB50 & 6 & $45,26 \pm 4,14^{*}$ & $16,68 \pm 8,85$ \\
RB100 & 5 & $53,80 \pm 4,04$ & $15,44 \pm 5,83$ \\
RB200 & 5 & $53,20 \pm 4,97$ & $17,42 \pm 6,49$ \\
\hline
\end{tabular}

$\mathrm{n}=$ número de animais

${ }^{*} p<0.05$, ANOVA seguida de Tukey-Kramer. 


\subsection{EXPERIMENTO VI - Efeito do resíduo butanólico sobre a atividade e/ou viabilidade de células do tumor de Ehrlich em cultura primária.}

A viabilidade das células tratadas com RB nas concentrações de $5000 \mu \mathrm{g} / \mathrm{mL}(\mathrm{F})$ e $10000 \mu \mathrm{g} / \mathrm{mL}(\mathrm{G})$ foi estatisticamente maior 24 horas após o tratamento, em relação ao controle, conforme ilustram as figuras 25 e 27 e a tabela 5. Já a viabilidade das células tratadas com RB em todas as concentrações, com exceção da concentração de $5000 \mu \mathrm{g} / \mathrm{mL}(\mathrm{F})$, foi estatisticamente menor 48 horas após o tratamento, em relação ao controle, conforme ilustram as figuras 26 e 27 e a tabela 5. Estes dados foram semelhantes aos obtidos com a realização de um segundo experimento independente.

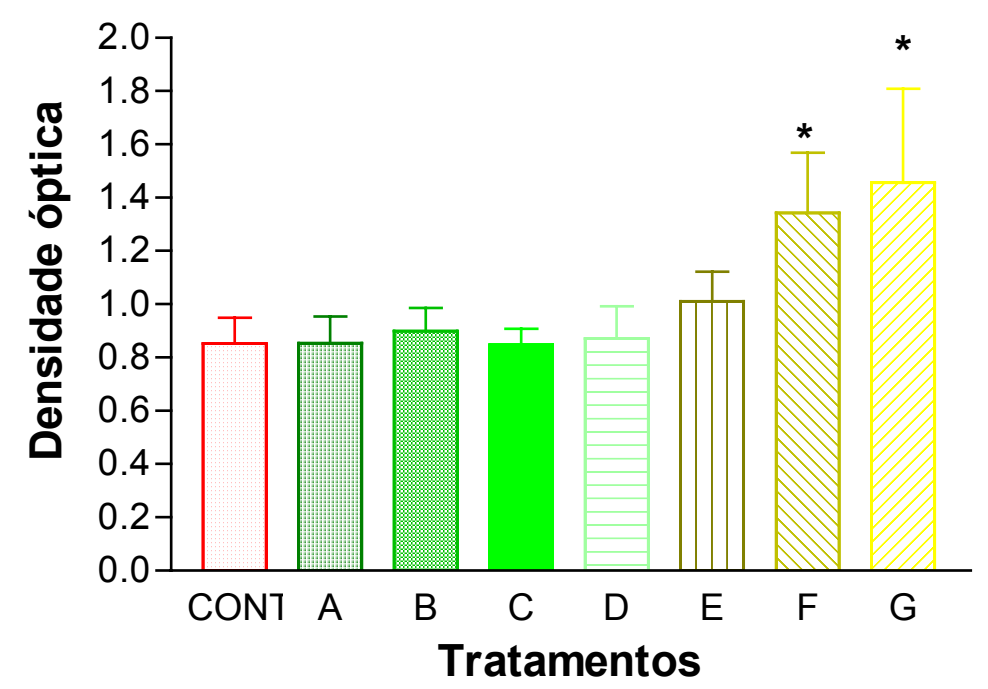

Figura 25 - Densidade óptica de células tratadas com RB nas concentrações de 100ng/mL (A), $1000 \mathrm{ng} / \mathrm{mL}(B), 10 \mu \mathrm{g} / \mathrm{mL}(C), 100 \mu \mathrm{g} / \mathrm{mL}$ (D), $1000 \mu \mathrm{g} / \mathrm{mL}(E), 5000 \mu \mathrm{g} / \mathrm{mL}(\mathrm{F})$ ou $10000 \mu \mathrm{g} / \mathrm{mL}(\mathrm{G})$, ou com água (CONT), 24 horas após o tratamento.

${ }^{*} p<0.05$, ANOVA seguida de Tukey-Krumer 


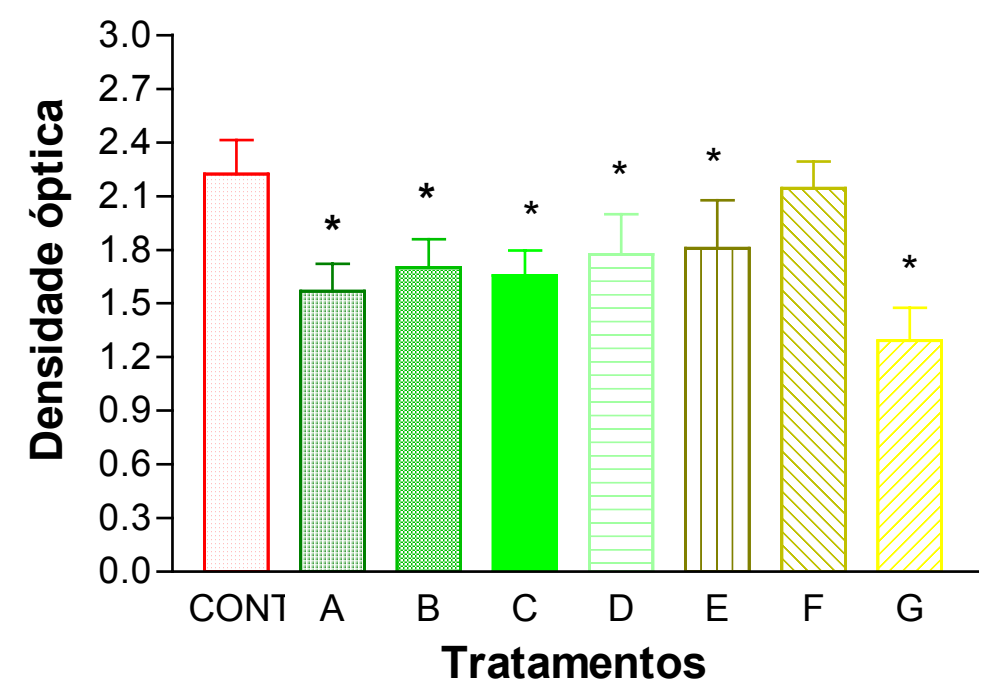

Figura 26 - Densidade óptica de células tratadas com RB nas concentrações de $100 \mathrm{ng} / \mathrm{mL}(A)$, $1000 \mathrm{ng} / \mathrm{mL}(B), 10 \mu \mathrm{g} / \mathrm{mL}(C), 100 \mu \mathrm{g} / \mathrm{mL}$ (D), $1000 \mu \mathrm{g} / \mathrm{mL}(E), 5000 \mu \mathrm{g} / \mathrm{mL}(F)$ ou $10000 \mu \mathrm{g} / \mathrm{mL}(\mathrm{G})$, ou com água (CONT), 48 horas após o tratamento.

${ }^{*} p<0.05$, ANOVA seguida de Tukey-Krumer 


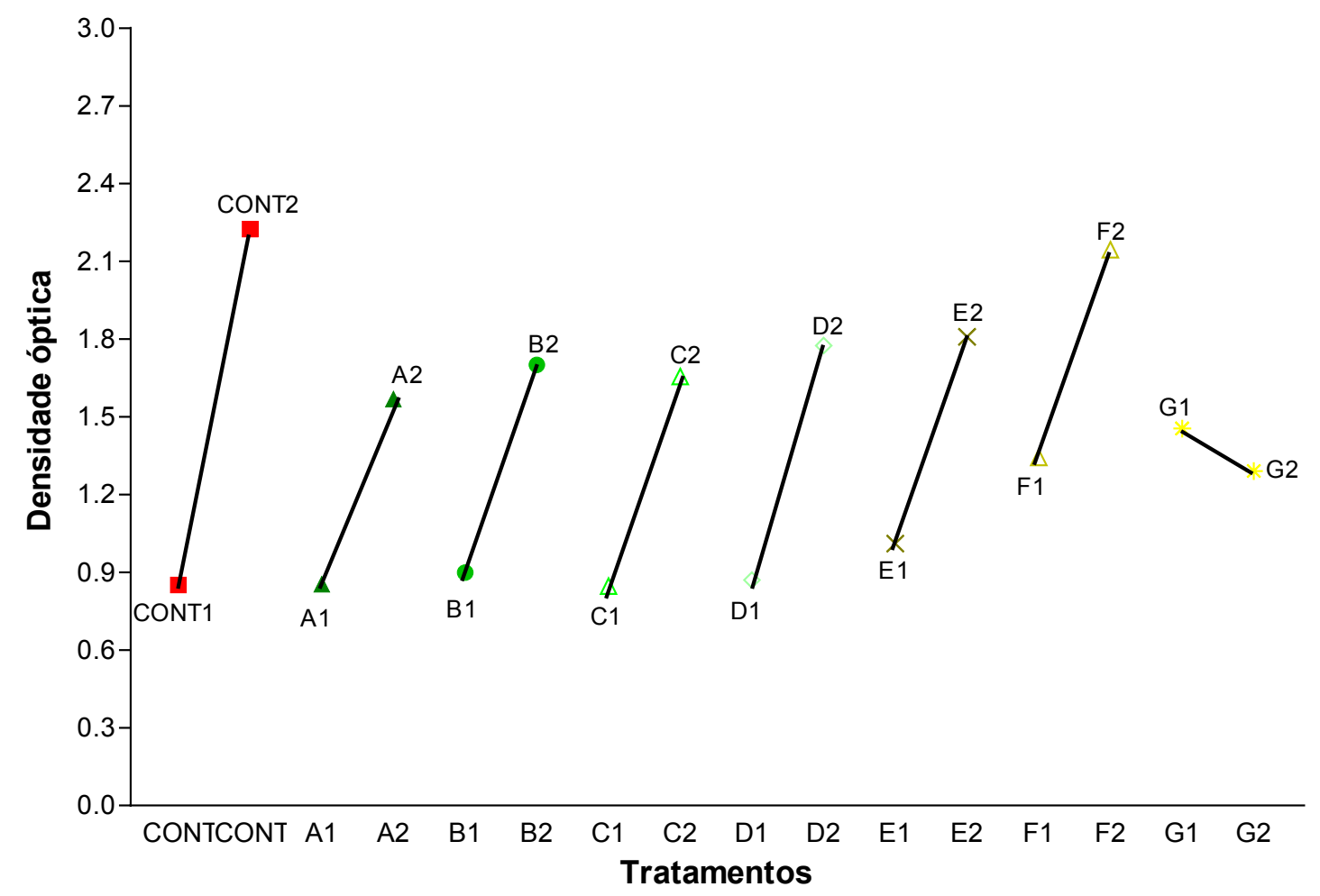

Figura 27 - Densidade óptica de células tratadas com RB nas concentrações de 100ng/mL (A1),

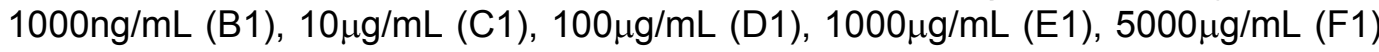
ou $10000 \mu \mathrm{g} / \mathrm{mL}$ (G1), ou com água (CONT1), 24 horas após o tratamento, ou com de $100 \mathrm{ng} / \mathrm{mL}$ (A2), $1000 \mathrm{ng} / \mathrm{mL}$ (B2), $10 \mu \mathrm{g} / \mathrm{mL}$ (C2), $100 \mu \mathrm{g} / \mathrm{mL}$ (D2), $1000 \mu \mathrm{g} / \mathrm{mL}$ (E2), $5000 \mu \mathrm{g} / \mathrm{mL}$ ( $F 2$ ) ou $10000 \mu \mathrm{g} / \mathrm{mL}$ (G2), ou com água (CONT2), 48 horas após o tratamento

${ }^{*} p<0.05$, ANOVA seguida de Tukey-Krumer 
Tabela 5- Densidade óptica de células tratadas com RB nas concentrações de $100 \mathrm{ng} / \mathrm{mL}(A)$, $1000 \mathrm{ng} / \mathrm{mL}(B), 10 \mu \mathrm{g} / \mathrm{mL}(C), 100 \mu \mathrm{g} / \mathrm{mL}$ (D), $1000 \mu \mathrm{g} / \mathrm{mL}(E), 5000 \mu \mathrm{g} / \mathrm{mL}(\mathrm{F})$ ou $10000 \mu \mathrm{g} / \mathrm{mL}(\mathrm{G})$, ou com água (CONT), 24 ou 48 horas após o tratamento.

\begin{tabular}{cccc}
\hline Tratamentos & $\mathbf{n}$ & $\begin{array}{c}\text { Densidade óptica } \\
\mathbf{2 4 h}\end{array}$ & $\begin{array}{c}\text { Densidade óptica } \\
\mathbf{4 8 h}\end{array}$ \\
\hline CONT & 5 & $0,85 \pm 0,09$ & $2,22 \pm 0,19$ \\
A & 6 & $0,85 \pm 0,10$ & $1,56 \pm 0,15^{*}$ \\
B & 6 & $0,89 \pm 0,08$ & $1,70 \pm 015^{*}$ \\
C & 6 & $0,84 \pm 0,06$ & $1,65 \pm 0,14^{*}$ \\
D & 6 & $0,87 \pm 0,12$ & $1,77 \pm 0,22^{*}$ \\
E & 6 & $1,01 \pm 0,11$ & $1,80 \pm 0,26^{*}$ \\
F & 6 & $1,34 \pm 0,22^{*}$ & $2,14 \pm 0,14$ \\
G & 6 & $1,45 \pm 0,35^{*}$ & $1,29 \pm 0,18^{*}$ \\
\hline
\end{tabular}

$\mathrm{n}=$ número de replicatas

${ }^{*} p<0.05$, ANOVA seguida de Tukey-Krumer

\subsection{EXPERIMENTO VII - Efeito do resíduo butanólico sobre as fases do ciclo de células do tumor de Ehrlich em cultura primária, $48 \mathrm{~h}$ após o tratamento}

As figuras 28 e 29 ilustram os citogramas representativos de células tumorais tratadas apenas com meio de cultura (controle) ou com RB na concentração de $10000 \mu \mathrm{g} / \mathrm{mL}$, respectivamente. As figuras 30 e 31 ilustram os histogramas de 
fluorescência FL-2 em escala linear representativos de células tumorais tratadas apenas com meio de cultura (controle) ou com RB na concentração de $10000 \mu \mathrm{g} / \mathrm{mL}$, respectivamente. As diferentes regiões analisadas neste histograma (M1, M2, M3 e M4) indicam o conteúdo de DNA e são delimitadas com base na intensidade de fluorescência das células.

A porcentagem de células hipodiplóides foi estatisticamente maior nas células tratadas com RB na concentração de $10000 \mu \mathrm{g} / \mathrm{mL}(\mathrm{G})$, em relação ao controle, conforme ilustra a figura 32 e tabela 6. Não houve diferença estatisticamente significante nas outras concentrações testadas.

A porcentagem de células na fase $\mathrm{G} 0$ ou $\mathrm{G} 1$ do ciclo foi estatisticamente menor nas células tratadas com RB nas concentrações de $5000 \mu \mathrm{g} / \mathrm{mL}(\mathrm{F})$ e $10000 \mu \mathrm{g} / \mathrm{mL}(\mathrm{G})$, em relação ao controle, conforme ilustra a figura 33 e tabela 6 . Não houve diferença estatisticamente significante nas outras concentrações testadas.

A porcentagem de células na fase $S$ foi estatisticamente maior nas células tratadas com RB na concentração de $5000 \mu \mathrm{g} / \mathrm{mL}(\mathrm{F})$, conforme ilustra a figura 34 e a tabela 6. Não houve diferença estatisticamente significante nas outras concentrações testadas.

A porcentagem de células na fase G2/M foi estatisticamente maior nas células tratadas com RB na concentração de $10000 \mu \mathrm{g} / \mathrm{mL}(\mathrm{G})$, conforme ilustra a figura 35 e a tabela 6. Não houve diferença estatisticamente significante nas outras concentrações testadas.

As células tratadas com a concentração $E$ foram retiradas da análise estatística devido à perda de 2 replicatas por contaminação dos poços. 


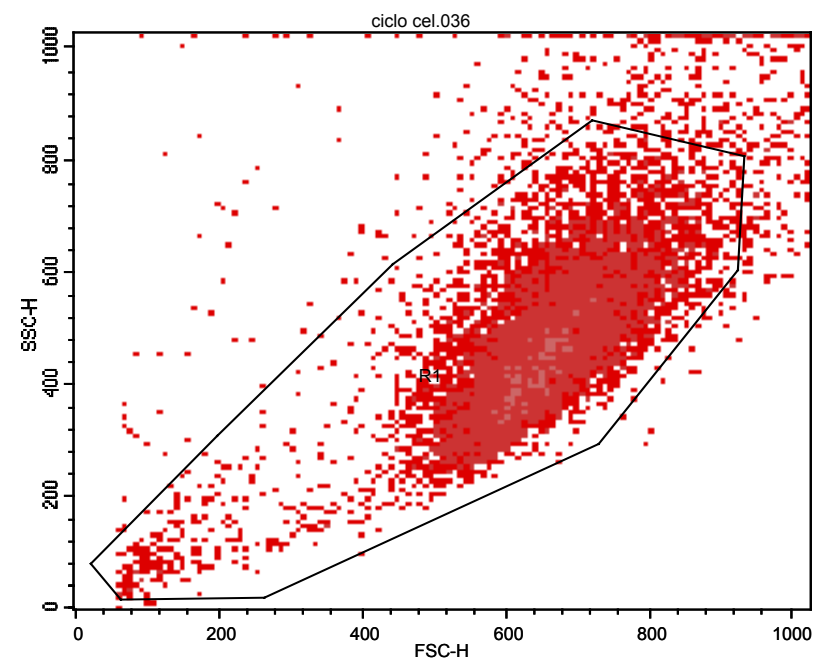

Figura 28 - Citograma de células do tumor de Ehrlich, ilustrando uma população R1 analisada e equivalente às células tumorais, 48 horas após o tratamento com meio de cultura (controle).

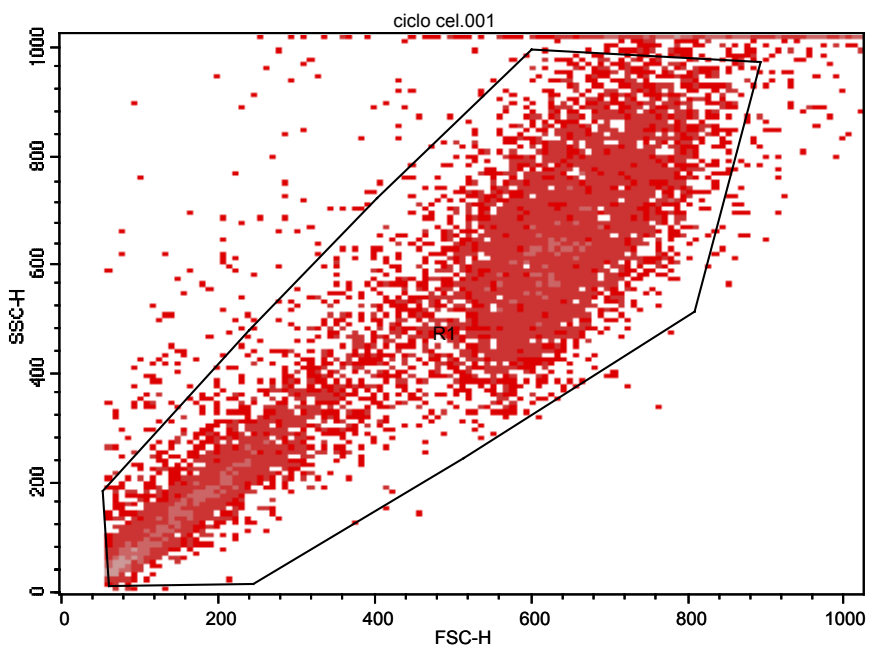

Figura 29 - Citograma de células do tumor de Ehrlich, ilustrando uma população R1 analisada e equivalente às células tumorais, 48 horas após o tratamento com resíduo butanólico na concentração de $10000 \mu \mathrm{g} / \mathrm{mL}$. 


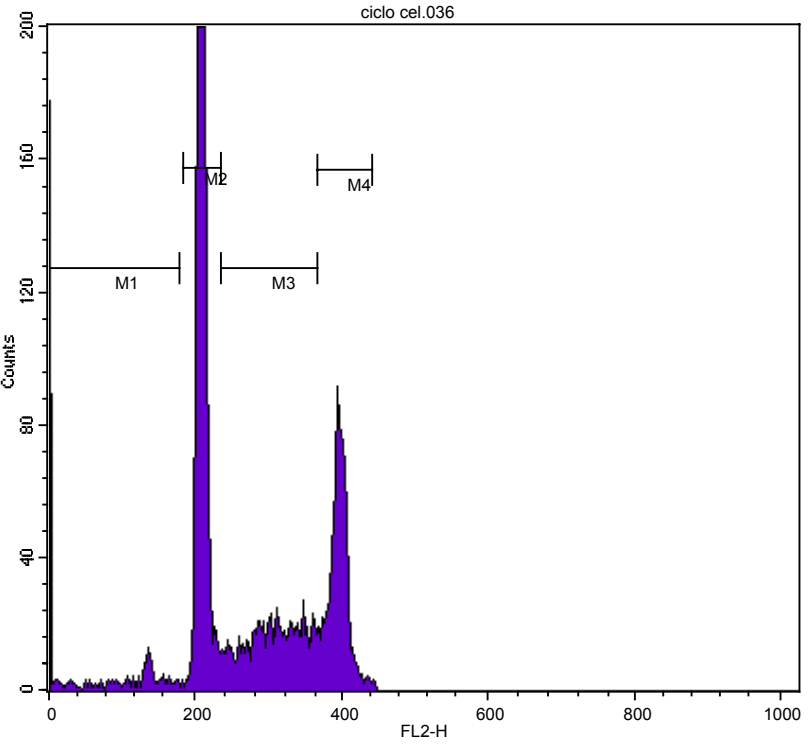

Figura 30 - Histograma do ciclo de células do tumor de Ehrlich ilustrando as quatro regiões analisadas: $M 1=$ células hipodiplóides, $M 2=$ células em fase $\mathrm{G} 0 / \mathrm{G} 1, \mathrm{M} 3$ = células em fase $\mathrm{S}, \mathrm{M} 4$ = células em fase $\mathrm{G} 2 / \mathrm{M}, 48$ horas após o tratamento com meio de cultura (controle).

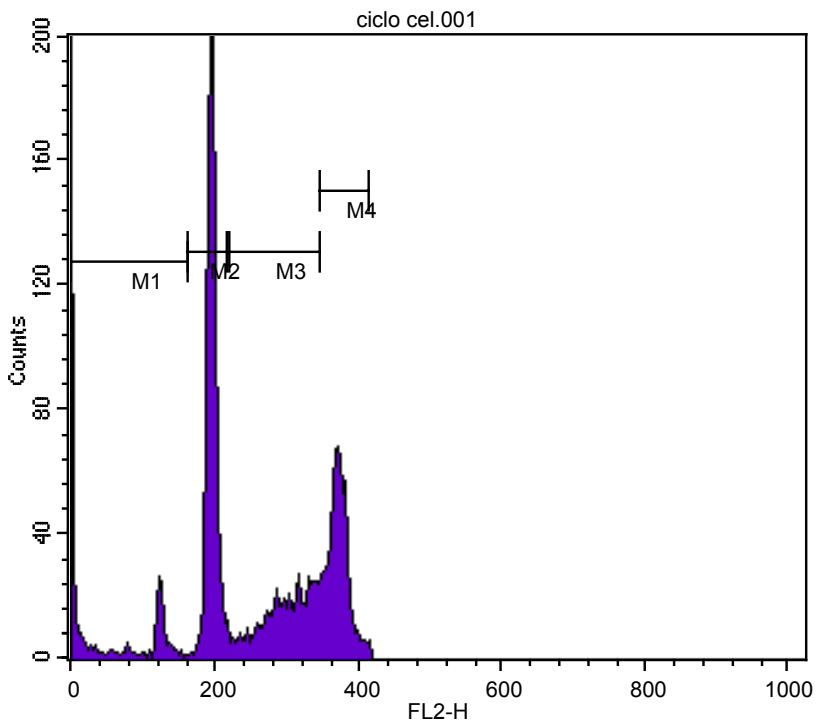

Figura 31 - Histograma do ciclo de células do tumor de Ehrlich ilustrando as quatro regiões analisadas: $\mathrm{M} 1=$ células hipodiplóides, $\mathrm{M} 2=$ células em fase G0/G1, M3 = células em fase $S, M 4$ = células em fase G2/M, 48 horas após o tratamento com RB na concentração de $10000 \mu \mathrm{g} / \mathrm{mL}$. 


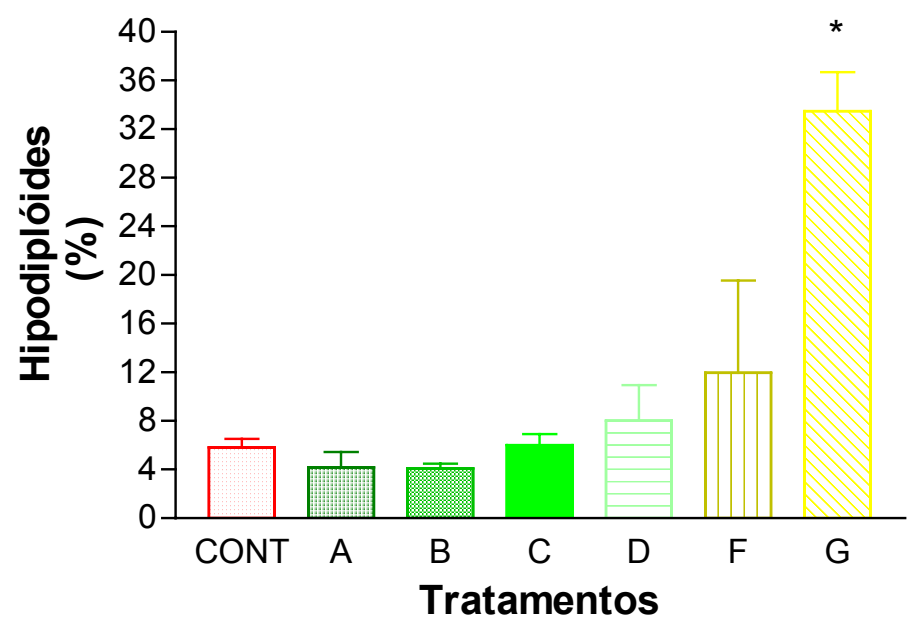

Figura 32 - Porcentagem de células hipodiplóides, 48 horas após o tratamento com RB nas

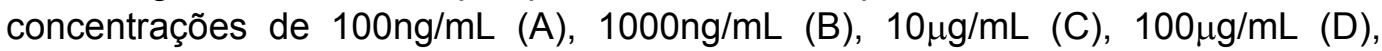
$5000 \mu \mathrm{g} / \mathrm{mL}(\mathrm{F})$ ou $10000 \mu \mathrm{g} / \mathrm{mL}(\mathrm{G})$, ou com água (CONT).

${ }^{*} p<0.05$, ANOVA seguida de Tukey-Krumer

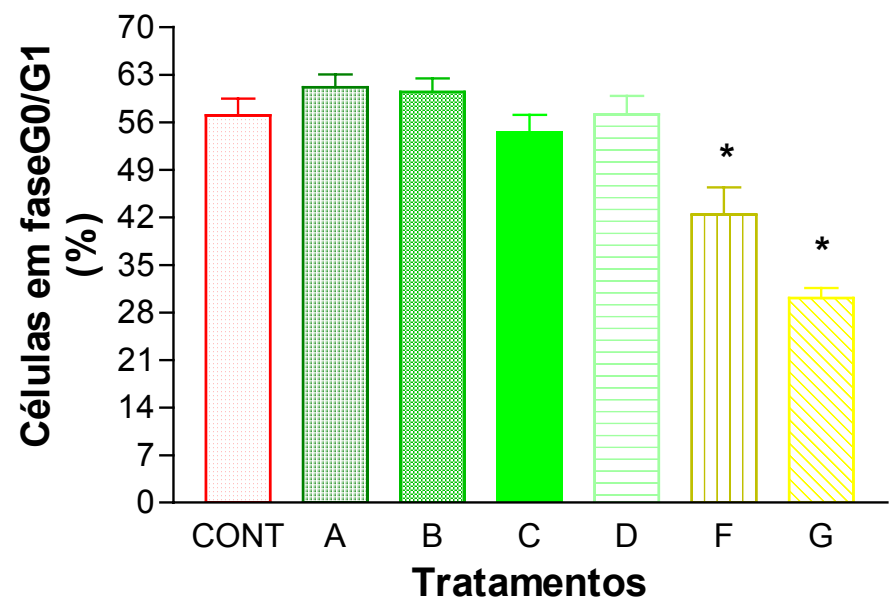

Figura 33 - Porcentagem de células em fase G0/G1, 48 horas após o tratamento com RB nas concentrações $100 \mathrm{ng} / \mathrm{mL}$ (A), 1000ng/mL (B), $10 \mu \mathrm{g} / \mathrm{mL}$ (C), $100 \mu \mathrm{g} / \mathrm{mL}$ (D), $5000 \mu \mathrm{g} / \mathrm{mL}(\mathrm{F})$ ou $10000 \mu \mathrm{g} / \mathrm{mL}(\mathrm{G})$, ou com água (CONT).

${ }^{*} p<0.05$, ANOVA seguida de Tukey-Krumer 


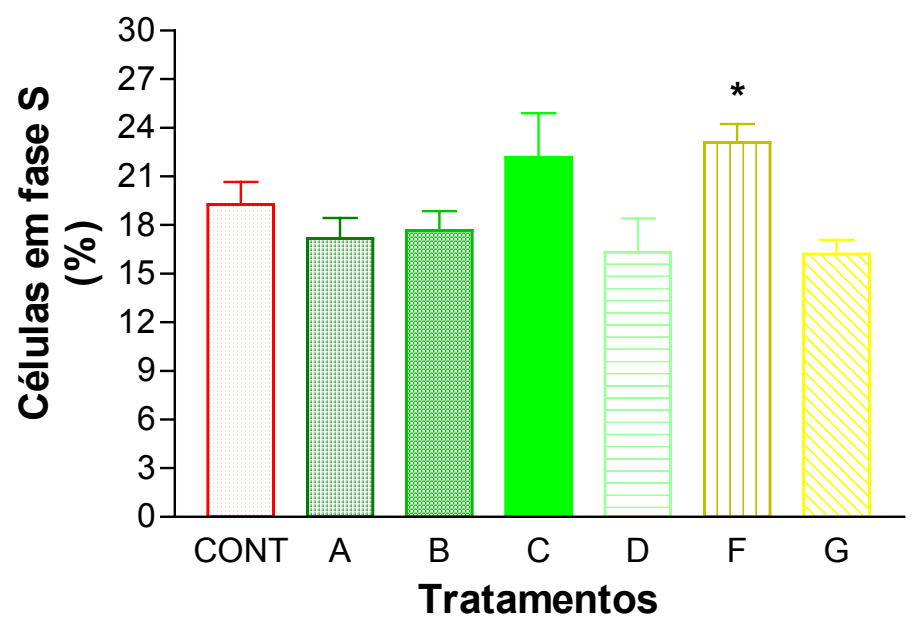

Figura 34 - Porcentagem de células em fase $S, 48$ horas após o tratamento com RB nas concentrações de $100 \mathrm{ng} / \mathrm{mL}$ (A), 1000ng/mL (B), $10 \mu \mathrm{g} / \mathrm{mL}$ (C), $100 \mu \mathrm{g} / \mathrm{mL}$ (D), $5000 \mu \mathrm{g} / \mathrm{mL}(\mathrm{F})$ ou $10000 \mu \mathrm{g} / \mathrm{mL}(\mathrm{G})$, ou com água (CONT).

${ }^{*} p<0.05$, ANOVA seguida de Tukey-Krumer

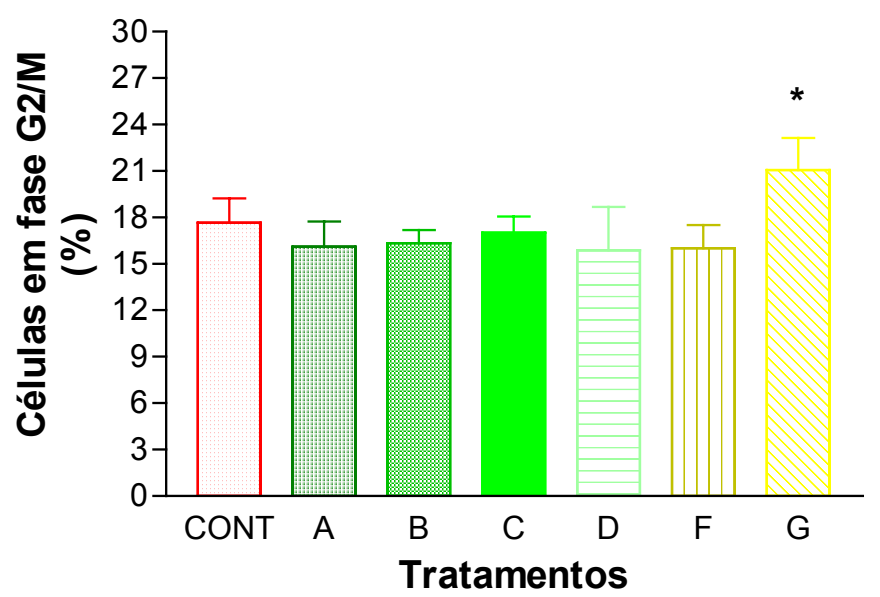

Figura 35 - Porcentagem de células em fase G2/M, 48 horas após o tratamento com RB nas concentrações $100 \mathrm{ng} / \mathrm{mL}$ (A), $1000 \mathrm{ng} / \mathrm{mL}$ (B), $10 \mu \mathrm{g} / \mathrm{mL}$ (C), $100 \mu \mathrm{g} / \mathrm{mL}$ (D), $5000 \mu \mathrm{g} / \mathrm{mL}(\mathrm{F})$ ou $10000 \mu \mathrm{g} / \mathrm{mL}(\mathrm{G})$, ou com água (CONT).

${ }^{*} p<0.05$, ANOVA seguida de Tukey-Krumer 
Tabela 6 - Porcentagem de células hipodiplóides, em fases G0/G1, S ou G2/M do ciclo celular de células tumorais tratadas com RB nas concentrações de 100ng (A), 1000ng (B), $10 \mu \mathrm{g}(\mathrm{C}), 100 \mu \mathrm{g}(\mathrm{D}), 5000 \mu \mathrm{g}(\mathrm{F})$ ou $10000 \mu \mathrm{g} / \mathrm{mL}(\mathrm{G})$, ou com água (CONT), 48 horas após o tratamento.

\begin{tabular}{cccccc}
\hline Grupos & $\mathbf{n}$ & Hipodiplóides (\%) & $\begin{array}{c}\text { Fase G0-G1 } \\
(\%)\end{array}$ & Fase S (\%) & Fase G2/M \\
\hline CONT & 6 & $5,83 \pm 0,70$ & $57,01 \pm 2,44$ & $19,26 \pm 1,4$ & $17,67 \pm 1,56$ \\
A & 6 & $4,18 \pm 1,26$ & $61,15 \pm 1,89$ & $17,18 \pm 1,26$ & $16,1 \pm 1,64$ \\
B & 5 & $4,07 \pm 0,41$ & $60,48 \pm 1,95$ & $17,68 \pm 1,18$ & $16,34 \pm 0,84$ \\
C & 5 & $6,00 \pm 0,91$ & $54,46 \pm 2,60$ & $22,18 \pm 2,74$ & $17,00 \pm 1,07$ \\
D & 5 & $8,03 \pm 2,92$ & $57,15 \pm 2,72$ & $16,34 \pm 2,07$ & $15,88 \pm 2,81$ \\
F & 6 & $11,96 \pm 7,59$ & $42,37 \pm 4,04 *$ & $23,12 \pm 1,12 *$ & $16,00 \pm 1,50$ \\
G & 4 & $33,47 \pm 3,22 *$ & $30,14 \pm 1,45 *$ & $16,21 \pm 0,88$ & $21,06 \pm 2,07 *$ \\
\hline
\end{tabular}

$\mathrm{n}=$ número de replicatas

${ }^{*} p<0.05$, ANOVA seguida de Tukey-Krumer 


\section{DISCUSSÃO}

As raízes de $P$. paniculata são comercialmente encontradas em forma de cápsulas, contendo as raízes pulverizadas e/ou seus extratos, ou em forma de soluções, contendo seus extratos.

Efeitos inibitórios sobre o desenvolvimento do tumor de Ehrlich, na forma ascítica, foram demonstrados, em animais tratados, por via oral, com as raízes pulverizadas de $P$. paniculata (MATSUZAKI et al., 2003). No presente estudo, estudamos os efeitos do tratamento, por via oral, com o extrato ou resíduos de $P$. paniculata sobre o desenvolvimento deste mesmo tumor.

Primeiramente, obtivemos o extrato etanólico; os resíduos aquoso e butanólico foram obtidos a partir deste extrato. O processo de extração permite a retirada de substâncias presentes na raiz, assim como o seu fracionamento; no caso, o extrato etanólico foi fracionado em resíduo aquoso e resíduo butanólico. Este procedimento permite a administração de maior concentração de substâncias potencialmente ativas presentes na raiz, em relação à administração em forma de raízes pulverizadas. Além disto, possibilita a avaliação de substâncias isoladamente, devido ao seu fracionamento.

Inicialmente, foi determinado o tempo de sobrevida de animais tratados com EE, RA ou RB, em 3 diferentes concentrações (50, 100 e $200 \mathrm{mg} / / \mathrm{Kg})$. Os grupos tratados com RB nas concentrações de 50 e 200 mg/Kg e o grupo tratado com RA na concentração de $100 \mathrm{mg} / \mathrm{Kg}$ apresentaram maior sobrevida em relação ao grupo controle. 
As médias de sobrevida de animais tratados com RB50, RB200 ou RA100 foram de 17,16 e 16 dias, respectivamente; nos animais controle, a média foi de 12 dias. A média de sobrevida corresponde ao tempo em que metade dos animais estava morta.

Devido ao fato de 2 concentrações de RB aumentarem o tempo de sobrevida dos camundongos portadores do TE, os efeitos do tratamento com este resíduo sobre outros parâmetros envolvidos no desenvolvimento tumoral foram avaliados nos experimentos posteriores. A concentração de $50 \mathrm{mg} / \mathrm{Kg}$ foi escolhida, pois levou a um maior aumento de sobrevida que a observada com a concentração de $200 \mathrm{mg} / \mathrm{Kg}$.

A fim de determinar se o tratamento com o RB poderia causar efeitos tóxicos, este resíduo foi administrado por 14 dias aos animais, correspondente ao tempo de tratamento ao qual os animais foram submetidos na maioria dos experimentos. Para este fim, a maior concentração de RB, equivalente a $200 \mathrm{mg} / \mathrm{Kg}$, foi utilizada. Foram avaliados o ganho de peso e alguns parâmetros da toxicidade hepática e renal.

O ganho de peso foi menor nos animais tratados com o RB, estatisticamente significante nos últimos dias do período experimental (dia 13 e 15). A concentração de $50 \mathrm{mg} / \mathrm{Kg}$, entretanto, utilizada nos experimentos posteriores, não causou alteração em relação ao peso dos animais (foi realizada a análise estatística do ganho de peso de animais tratados com RB50, referente ao experimento com o tumor na forma sólida, dados não demonstrados). O exame histopatológico de fígado, baço e rim, juntamente com a determinação das atividades das enzimas AST, ALT e $\gamma$-GT, e da concentração sérica de uréia e creatinina, não revelaram sinais de toxicidade nestes órgãos. Assim, concluímos que a administração de RB na concentração de $50 \mathrm{mg} / \mathrm{Kg}$, por 14 dias, não causou efeitos tóxicos. 
Para investigar se o aumento de sobrevida observado no primeiro experimento foi devido a um menor desenvolvimento tumoral, foi realizado um segundo experimento. Assim, o mesmo protocolo de tratamento foi realizado, porém 7 dias após a inoculação do tumor os animais foram eutanasiados, sendo quantificado o volume de fluído ascítico, número de células tumorais/mL e número de células tumorais totais.

O volume do fluído ascítico e número de células tumorais totais foi menor nos animais tratados com RB50 em relação aos animais controle, porém não estatisticamente significante $(p>0.05)$. Frente a estes resultados, e juntamente com os resultados apresentados no experimento de sobrevida, podemos considerar que, apesar dos animais tratados com RB50 desenvolverem o tumor, há uma atenuação do crescimento tumoral, ou seja, um crescimento mais lento do tumor, nestes animais. Devido a esta atenuação, os animais tratados com RB50 (experimento de sobrevida) vêm a óbito mais tardiamente.

A atenuação do crescimento tumoral observada pode ser devida a um menor desenvolvimento do fluído ascítico, a uma maior atividade de macrófagos, a uma menor proliferação das células tumorais ou à ocorrência de morte celular.

No experimento de sobrevida, uma diminuição do fluído ascítico em tempos posteriores ao $7^{\circ}$ dia (que foi o dia padronizado para se avaliar o volume do fluído ascítico nos experimento com o tumor na forma ascítica) poderia estar presente. $\mathrm{O}$ tratamento de animais com raízes pulverizadas de $P$. paniculata por 20 dias, na concentração de $200 \mathrm{mg} / \mathrm{Kg}$, causou uma diminuição do volume do fluído ascítico dos animais inoculados com o TE intraperitonealmente (MATSUZAKI et al., 2003), indicando um possível efeito antiinflamatório de $P$. paniculata. 
Uma das causas de morte em camundongos portadores do TAE se deve à pressão mecânica exercida pelo aumento progressivo do fluído ascítico nesses animais; além disto, sabe-se que uma diferença no crescimento tumoral é acompanhada por uma diferença na quantidade de fluído ascítico presente (HARVEIT, 1965). Desta maneira, uma hipótese seria a de que o RB50 causaria uma diminuição do fluído ascítico.

Outros estudos demonstraram que o extrato etanólico de $P$. paniculata, administrado intraperitonealmente ou subcutaneamente em ratos, possui efeito analgésico-antiinflamatório em edema induzido por carragenina (MAZZANTI; BRAGHIROLI, 1994). Foram obtidos também efeitos antiinflamatórios ao se utilizar extrato metanólico de Pfaffia iresinoides, outra espécie de Pfaffia, em alguns modelos experimentais de inflamação em ratos, quando administrado aos animais por via oral (TANIGUCHI et al., 1997).

Popularmente, as raízes de $P$. paniculata são utilizadas principalmente como tônicas, sendo atribuídas também a estas raízes propriedades imunoestimulantes. A fim de se avaliar se o aumento de sobrevida observado nos animais tratados com RB estaria relacionado a estas propriedades, alguns parâmetros da atividade imunológica foram avaliados, como a atividade macrofágica medida pela capacidade de fagocitose e burst oxidativo.

Sabe-se que os macrófagos representam uma das principais células efetoras da imunidade celular; o macrófago em estado ativado possui maior capacidade de promover a morte de microorganismos e de células tumorais, e apresenta várias alterações em seu metabolismo e estrutura (KOOPER; LAPIS, 1985). 
A resposta inflamatória parece ser importante no desenvolvimento do TE, influenciando o seu crescimento (GUERRA, 1983). O lavado peritoneal de camundongos inoculado com o TE, 24 a 48h após a inoculação, apresenta um maior número de macrófagos, linfócitos e polimorfonucleares (SEZZI; BELELLI; NISTA, 1972). GUERRA (1983) e FECCHIO (1989) demonstraram um aumento da atividade de macrófagos peritoneais em animais inoculados com células do TE, intraperitonealmente, em tempos iniciais à inoculação.

Estudos mostram que os macrófagos peritoneais não fagocitam células tumorais viáveis, porém podem fagocitar células tumorais previamente irradiadas ou mortas antes da inoculação intraperitoneal (SEZZI; BELELLI; NISTA, 1972; VORBRODT et al., 1973). Os animais portadores deste tumor na forma ascítica vêm a óbito por diversos fatores, como pela intensa hemorragia intraperitoneal (HARVEIT, 1965), pela própria pressão mecânica exercida pelo aumento progressivo do fluído ascítico (HARVEIT, 1965), ou devido à substâncias tóxicas liberadas pelas células tumorais degeneradas (MAYER, 1966) ou pelo próprio organismo. Desta maneira, acreditamos que o papel dos macrófagos no desenvolvimento do TE seria principalmente atuar sobre as células tumorais nos momentos iniciais à inoculação, fagocitando as células tumorais injuriadas, e possivelmente evitando a liberação de substâncias tóxicas pelas mesmas. Nas fases mais posteriores à inoculação, atuariam fagocitando as células tumorais que vão se tornando inviáveis.

Neste projeto, avaliamos a atividade macrofágica por meio da citometria de fluxo. Esta técnica possui a vantagem de identificar e avaliar a resposta de populações celulares sem a necessidade da separação prévia das células, o que poderia alterar a 
função celular, podendo ativar per se o burst oxidativo celular (FEARON; COLLINS, 1983).

Foi demonstrado que a oxidação do DCFH-DA é quantitativamente proporcional à concentração de $\mathrm{H}_{2} \mathrm{O}_{2}$ gerado pela célula (HIRABAYASHI; TANIUCHI; KOBAYASHI, 1985). O burst oxidativo expresso na geração de $\mathrm{H}_{2} \mathrm{O}_{2}$ por macrófagos é quantificado indiretamente usando-se como reagente o DCFH, o $S$. aureus marcado com iodeto de propídeo e o PMA. Por outro lado, a capacidade de fagocitose é medida pela porcentagem de macrófagos que fagocitaram o $S$. aureus e pela intensidade de fagocitose (quantidade de bactérias internalizadas), medida pela intensidade de fluorescência emitida pelo iodeto de propídeo ligado à bactéria.

Ao contrário dos resultados esperados, animais tratados com RB50, durante os 7 dias anteriores à inoculação do tumor, apresentaram menor atividade macrofágica, referente ao burst oxidativo. O burst estimulado por $S$. aureus foi significantemente menor nos animais tratados com RB, e menor, porém não estatisticamente significante, no estimulado por PMA ou espontâneo. O tratamento com RB não alterou a capacidade de fagocitose pelos macrófagos, refletida pela porcentagem de macrófagos que fagocitaram e pela intensidade de fagocitose.

Desta maneira, a utilização de $P$. paniculata como imunoestimulante deve ser cautelosa. O aumento de sobrevida provavelmente não foi devido a uma maior atividade de macrófagos, pelo menos no dia posterior à inoculação do tumor.

Foram avaliados também os efeitos do tratamento com 0 RB sobre 0 crescimento do TE na forma sólida. A evolução da espessura dos coxins plantares e a porcentagem de necrose em meio à massa tumoral não diferiu entre os animais tratados com as 3 concentrações de RB e os animais controle. 
A porcentagem de células positivas para o PCNA foi significantemente menor nos animais tratados com RB50, porém a espessura do coxim plantar destes animais permaneceu maior que a dos animais controle durante quase todo o período experimental, embora sem significância estatística. Como a porcentagem de necrose na área tumoral entre os animais tratados com as 3 concentrações de RB e os animais controle não diferiu significantemente, podemos inferir que o grupo tratado com RB50 apresenta maiores valores absolutos tanto de área tumoral quanto de necrose. Assim, apesar de haver uma diminuição na porcentagem de células em proliferação nos animais tratados, esta diminuição, em valores absolutos, pode não estar presente.

Resumidamente, o tratamento com RB, apesar de levar a um aumento de sobrevida e a uma atenuação do crescimento do tumor na forma ascítica, não foi capaz de diminuir o crescimento do tumor na forma sólida. Uma hipótese para este fenômeno seria a de que, diferentemente da alta vascularização presente no peritôneo, o tumor sólido, que apresenta uma menor vascularização, permitiria um menor acesso do RB (ou seus metabólitos) ao local. Além disto, o microambiente em que as células tumorais se encontram diferem entre estes dois modelos, o que poderia causar respostas diferentes do tumor à ação de substâncias presentes no resíduo.

Desta forma, acreditamos que uma administração intraperitoneal ou intratumoral do RB poderia ser mais efetiva, já que os efeitos parecem ser tópicos. De fato, trabalhos recentes demonstraram melhores resultados ao se utilizar o tratamento intraperitoneal em pacientes com câncer de ovário (ALBERTS et al., 1996).

Em uma outra etapa do projeto, foram realizados experimentos utilizando cultura primária do tumor de Ehrlich, a fim de se avaliar os efeitos diretos do RB sobre as células tumorais. 
A técnica do MTT e a técnica para a avaliação das fases do ciclo celular em que as células se encontram foram realizadas. A técnica do MTT, baseada na metabolização dos sais de tetrazolium (MTT) por enzimas mitocondriais de células viáveis (MOSMANN, 1983), avalia a atividade celular, ou seja, quanto maior a atividade celular ou quanto maior o número de células viáveis, maior a conversão deste sal. Esta técnica, se utilizada isoladamente, não distingue se há uma alteração na atividade celular ou alteração no número absoluto de células. Desta maneira, realizamos também a determinação da porcentagem de células hipodiplóides, assim como nas fases G0/G1, S e G2/M do ciclo celular.

As concentrações utilizadas de RB foram 100ng/mL (A), 1000ng/mL (B), $10 \mu \mathrm{g} / \mathrm{mL}(\mathrm{C}), 100 \mu \mathrm{g} / \mathrm{mL}$ (D), 1000 $\mathrm{g} / \mathrm{mL}$ (E), 5000ng/mL (F) e 1000ng/mL (G). O ensaio de MTT foi realizado 24 e 48h após o tratamento, e a determinação das porcentagens de células em cada fase do ciclo celular, 48 horas após o tratamento.

O ensaio do MTT revelou menor viabilidade/atividade das células tratadas com todas as concentrações de RB, estatisticamente significante em todas as concentrações exceto F, 48 horas após o tratamento. Interessantemente, maior atividade/viabilidade, estatisticamente significante, foi detectada nas concentrações F e G, 24 horas após o tratamento. Resultados semelhantes foram obtidos com a realização de um segundo experimento independente.

$\mathrm{Na}$ análise do ciclo celular, 48 horas após o tratamento, a porcentagem de células mortas, hipodiplóides, foi estatisticamente maior na concentração de $10000 \mu \mathrm{g} / \mathrm{mL}(\mathrm{G})$ e maior, porém não significantemente, nas concentrações $F, D$ e C. A 
diminuição da densidade óptica medida no ensaio do MTT provavelmente se deve a um menor número de células viáveis presentes, nas maiores concentrações utilizadas.

A porcentagem de células na fase G0/G1 do ciclo celular foi significantemente menor nas concentrações $F$ e $G$, em relação ao controle. A porcentagem de células na fase $S$ diferiu apenas com a concentrações $F$, e a porcentagem de células na fase G2/M diferiu apenas com a concentração G, em relação ao controle. Devido ao fato das porcentagens das células nestas fases (S e G2/M) do ciclo não se apresentarem de maneira dose-dependente, esta diferença não será discutida neste projeto.

Pode-se inferir que o RB, neste modelo in vitro, não interfere com a capacidade de proliferação celular, pois não houve diferença quanto à porcentagem de células na fase de síntese. A porcentagem de células nas fases G0/G1 diminuiu proporcionalmente ao aumento da porcentagem de células mortas. Podemos concluir, frente a estes resultados e juntamente com os resultados obtidos com o ensaio do MTT, que o RB causa a morte de células especificamente em fase G0/G1 do ciclo celular.

Com o advento da citometria de fluxo, tornou-se possível a mensuração do conteúdo de DNA e outras características das células individualmente, rápida e acuradamente. Em combinação com outras técnicas, alterações na distribuição das fases do ciclo de células tratadas in vitro podem fornecer informações a respeito da especificidade ou sensibilidade, se houver, da fase do ciclo celular em que a droga apresenta maior ação citotóxica

Um agente que interferisse com a habilidade da célula tumoral proliferar seria um meio ideal de controlar o crescimento tumoral. A princípio, seria uma prática relativamente simples, uma vez que está disponível uma variedade de agentes antineoplásicos extremamente tóxicos a células em fase de proliferação. Na prática, 
porém, o problema é mais complexo. Apesar das células tumorais crescerem sem respeitar os mecanismos de controle do crescimento normal (HANH e WEINBERG, 2002), a velocidade de crescimento destas células raramente é maior que a das células normais. Além disto, enquanto alguns tumores possuem uma alta proporção de células em proliferação, como por exemplo, leucemias e linfomas, a maioria dos tumores malignos possui relativamente uma baixa fração de células em proliferação, e assim são menos susceptíveis a tratamentos com agentes que afetam, por exemplo, a habilidade das células sintetizarem DNA.

Os experimentos in vitro realizados neste projeto nos levam a concluir que o RB possui uma ação citotóxica em células em fase G0 e/ou G1. Os mecanismos responsáveis por esta especificidade deverão ser elucidados.

Sabe-se que a morte celular pode ocorrer por mecanismos apoptóticos ou por mecanismos não apoptóticos, também denominados “oncose" (LEVIN et al., 1999, OKADA; MAK, 2004). Embora a resistência à apoptose de células tumorais esteja bem descrita e intimamente relacionada à tumorigênese, a célula tumoral pode morrer por mecanismos não apoptóticos, como necrose, senescência, autofagia ou catástrofe mitótica (OKADA; MAK, 2004).

A apoptose, ao contrário da necrose, participa ativamente de seu próprio processo de morte, estando presente, por exemplo, em injúrias causadas por radiação ou por vários agentes antineoplásicos (LEVIN et al., 1999). A necrose ocorre normalmente como conseqüência de condições patofisiológicas, como radiação, infecção, inflamação ou isquemia (LEVIN et al., 1999; OKADA; MAK, 2004).

A senescência, por outro lado, é um processo bem descrito in vitro. As células em cultura primária inicialmente sofrem um período de rápida proliferação, onde os 
seus telômeros se encurtam. Finalmente, o crescimento celular diminui e as células saem do ciclo, permanentemente, sendo este processo denominado senescência replicativa (OKADA; MAK, 2004). A senescência pode, porém, ser induzida por outros mecanismos (CAMPISI, 2001), e embora não haja encurtamento dos telômeros nestes casos, as células apresentam outras características de senescência.

A autofagia, por outro lado, ocorre em resposta à retirada de fatores de crescimento do meio em que as células se encontram, ou devido à diferenciação celular (OKADA e MAK, 2004), porém não se sabe exatamente qual a função deste tipo de morte celular.

A catástrofe mitótica, finalmente, é a morte celular causada quando há um defeito no checkpoint G2 e a célula entra em mitose prematuramente, antes do término da replicação ou reparo de seu DNA (OKADA; MAK, 2004).

Estes tipos de morte diferem em seus aspectos morfológicos e bioquímicos. Para se determinar o mecanismo de morte celular observado nos experimentos in vitro apresentados nesta dissertação, seria necessário a realização de outras técnicas, como por exemplo a análise morfológica e/ou a análise de proteínas pró e anti-apoptóticas. Devemos considerar também que estes tipos de morte podem ocorrer conjuntamente, porém não se sabe se estes mecanismos de morte estão inter-relacionados.

Estudos pilotos de análise morfológica de células tumorais tratadas in vitro com o $\mathrm{RB}$ foram realizados em outros projetos relacionados a este. As células tratadas apresentaram morfologia distinta das células não tratadas, como a presença de células gigantes e multinucleadas, alterações estas associadas à morte celular por catástrofe 
mitótica. Mais estudos, no entanto, deverão ser realizados a fim de se definir o tipo de morte celular causada pelo RB.

As células tumorais freqüentemente apresentam alterações em uma destas vias de morte celular discutidas acima, porém elas ainda podem morrer em resposta a determinadas drogas devido à redundância destes mecanismos de morte. A determinação da via de morte defeituosa em cada tipo de tumor, assim como o tipo de morte que determinada droga apresenta maior probabilidade de causar, é importante para o desenho de melhores estratégias de tratamento.

Para finalizar, os efeitos mais marcantes observados nos experimentos realizados in vitro em relação aos in vivo podem ser explicados por diferenças intrínsecas pertinentes a cada tipo de modelo, como por exemplo, a metabolização de drogas que ocorre in vivo (IYER; RATAIN, 1998).

É possível que o RB, administrado por via oral, sofra metabolização antes de atingir a corrente sanguínea; assim, os princípios ativos que estariam atuando nas células tumorais in vitro e in vivo podem ser diferentes. Além disto, não sabemos qual concentração de RB alcançou o fluído ascítico nos animais tratados com este resíduo, possivelmente diferente das concentrações efetivas de RB utilizada in vitro.

Outras diferenças, como a interação entre a célula tumoral e as células estromais, e a inativação de drogas pelo hospedeiro, presente apenas nos modelos in vivo, também devem ser consideradas.

Resumidamente, o aumento de sobrevida e a atenuação do crescimento tumoral de animais portadores do tumor de Ehrlich na forma ascítica, tratados com o resíduo butanólico, pode ser devido a um menor desenvolvimento do fluído ascítico ou devido à ocorrência de morte celular. Os macrófagos não parecem ser responsáveis por estes 
efeitos observados. Além disso, não houve diferença quanto à porcentagem de células tumorais em proliferação, em animais portadores do tumor na forma sólida tratados com o resíduo, e em cultura celular. Por outro lado, o resíduo levou a uma maior morte celular nas células deste tumor em cultura primária. 


\section{CONCLUSÕES}

7.1 O resíduo butanólico (RB) de Pfaffia paniculata $(50 \mathrm{mg} / \mathrm{Kg})$ causou um aumento de sobrevida e uma atenuação do crescimento tumoral na forma ascítica.

7.2 O tratamento com o RB $(200 \mathrm{mg} / \mathrm{kg})$, durante 14 dias, levou a um menor ganho de peso dos animais, estatisticamente significante nos últimos dias do período experimental, porém não houve indícios de toxicidade hepática e renal.

7.3 O RB (50, 100 ou $200 \mathrm{mg} / \mathrm{Kg})$ não causou a diminuição do crescimento do tumor na forma sólida.

$7.4 \mathrm{O}$ tratamento prévio com RB $(50 \mathrm{mg} / \mathrm{Kg})$, em animais inoculados com o tumor de Ehrlich, causou uma diminuição do burst oxidativo estimulado por $S$. aureus em macrófagos, medido 24 horas após a inoculação do tumor.

$7.5 \mathrm{O}$ tratamento prévio com RB $(50 \mathrm{mg} / \mathrm{Kg})$, em animais inoculados com o tumor de Ehrlich, não alterou o burst oxidativo espontâneo ou induzido por PMA, medido 24 horas após a inoculação do tumor.

7.6 In vitro, o RB, na maioria das concentrações testadas, levou a uma diminuição da viabilidade celular 48 horas após o tratamento das células. 
7.7 In vitro, o RB, na maior concentração testada $(10000 \mu \mathrm{g} / \mathrm{mL})$, causou um aumento na porcentagem de células hipodiplóides ou mortas.

7.8 In vitro, o RB, nas duas maiores concentrações testadas $(10000$ e $5000 \mu \mathrm{g} / \mathrm{mL})$, causou uma diminuição na porcentagem de células nas fases $\mathrm{G} 0$ e $\mathrm{G} 1$ do ciclo celular. 


\section{BIBLIOGRAFIA}

ABBAS, A. K.; LICTHMAN, A. H.; POBER, J. S. Celular and molecular immunology. Philadelphia: Saunders, 1994. 457 p.

ALBERTS, D. S.; LIU, P. Y.; HANNIGAN, E. V.; O’TOOLE, R.; WILLIANS, S. D.; YOUNG, J. A.; FRANKLIN, E. W.; CLARKE-PEARSON, D. L.; MALVIYA, V. Y.; DUBESHTER, B. Intraperitoneal cisplatin plus intravenous cyclosphosphamide versus intravenous cisplatin plus intravenous cyclophosphamide for stage III ovarian cancer. The New England Journal of Medicine, v. 335, n. 26, p. 1950-1955, 1996.

AMES, B. N.; SHIGENAGA, M. K.; HAGEN, I. M. Oxidants, antioxidants, and the degenerative diseases of aging. Proceedings of the National Academy of Sciences of the United States of America, v. 90, n. 17, p. 7915-7922, 1993.

BAGULEY, B. C.; MARSHALL, E. S. In vitro modelling of human tumor behavior in drug discovery programmes. European Journal of Cancer, v. 40, p. 794-801, 2004.

BELTRÃO-BRAGA, P. C. B.; TEIXEIRA, V. R.; CHAMMAS, R. Transformação celular. Disponível em: < http:// www.usp.br/fm/direxlim/download/transc.pdf>. Acesso em: 01 set. 2004.

BEREMBLUM, I. The nature of tumor growth. In: FLOREY, L. General pathology. 4. ed. Philadelphia: W.B. Sauders, 1970. 655 p.

BRIDGES, A. J. The epidermal growth factor receptor family of tirosine kinases and cancer: xan an atypical exemplar be a sound therapeutic target? Current Medicinal Chemistry, v. 3, p. 211-226, 1996.

CAMPBELL, J. M.; CAMPBELL, J. B. Matemática em hematologia. In Matemática de laboratório. 3. ed. São Paulo: Roca, 1986. p. 185-202.

CAMPISI, J. Cellular senescence as a tumor-supressor mechanism. Trends in Cell Biology, v.11, p. S27-S31, 2001. 
CHEEKE, P. R. Biological effects of feed and forage saponins and their impacts on animal production. Advances in Experimental Medicine and Biology, v. 405, p. 377385, 1996.

CHEN, L.; WATKINS, J. F. Evidence against the presence of $\mathrm{H} 2$ histocompatibility antigens in Ehrlich ascites tumor cells. Nature, v. 225, p. 734-735, 1970.

COTRAN, R. S.; KUMAR, V.; ROBBINS, S. L. Neoplasia. In basis of disease. 4. ed. Philadelphia: W. B. Saunders, 1989. p. 239-305.

Robbins pathologic

DAGLI, M. I. Z. Disseminação linfática do tumor de Ehrlich: estudo experimental, 1989. $148 \mathrm{f}$. Tese (Mestrado em Patologia) - Faculdade de Medicina Veterinária e Zootecnia, Universidade de São Paulo, São Paulo, 1989.

DAGLI, M. L. Z.; GUERRA, J. L.; SALDIVA, P. H. N. An experimental study on the lymphatic dissemination of the solid Ehrlich tumor in mice. Brazilian Journal of Veterinary Research and Animal Science, v. 29, n. 1, p. 97-103, 1992.

EHRLICH, P.; APOLANT, H. Beobachtungen uber maligne mausetumoren. Berliner Klinischer Ocheschirift, v. 28, p. 871-874, 1906.

EVANS, H. J. Molecular genetic aspects of human cancers: the 1993 Franck Rose Lecture. British Journal of Cancer, v. 68, p.1051-1060, 1993.

EVANS, R.; ALEXANDER, P. Cooperation of immune lymphoid cells with macrophages in tumor immunity. Nature, v. 228, p. 620-622, 1970.

FARBER, E. The multistep nature of cancer development. Cancer Research, v. 44, p. 4217-4223, 1984.

FASTAIA, J,; DUMONT, A. E. Pathogenesis of ascites in mice with peritoneal carcinomatosis. Journal of the National Cancer Institute, v. 56, n. 3, 1976.

FEARON, D. T.; COLLINS, L. A. Increased expression of C3b receptors on polymorphonuclear leukocytes induced by chemostactic factors and purification procedures. The Journal of Imumunology, v. 130, p. 370-375, 1983. 
FECCHIO, D. Inflamação e tumor de Ehrlich. 1989. 110 f. Tese (Doutorado em Ciências) - Instituto de Ciências Biomédicas, Universidade de São Paulo, São Paulo, 1989.

FRUEHAUF, J. P. In vitro assay-assisted treatment selection for women with breast or ovarian cancer. Endocrine-Related Cancer, v. 9, p. 171-182, 2002.

GOLDIN, A.; VENDITTI, J. M.; MACDONALDS, J. S. Current results of the screening program at the Division of Cancer Treatment, National cancer Institute. European Journal of Cancer, v. 17, p. 129-142, 1981.

GOMES, C. O. M. S. Receptores benzodiazepínicos periféricos e resposta imune inata de eqüinos: efeitos do midazolam, 2003. 125 f. Tese (Doutorado em Patologia) - Faculdade de Medicina Veterinária e Zootecnia, Universidade de São Paulo, São Paulo, 2003.

GOUGH, M. J.; MELCHER, A. A.; AHMED, A.; CRITTENDEN, M. R.; RIDDLE, D. S.; LINARDAKIS, E.; RUCHATZ, A. N.; EMILIUSEN, L. M.; VILE, R. J. Macrophages orchestrate the immune response to tumor cell death. Cancer Research, v. 61, p. 72407247, 2001.

GUERRA, J. L. Aspectos do processo inflamatório em camundongos portadores de tumor de Ehrlich. 1983. 79 f. Tese (Doutorado em Patologia) - Faculdade de Medicina Veterinária e Zootecnia, Universidade de São Paulo, São Paulo, 1983.

HAHN, W.; WEINBERG, R. A. Modelling the molecular circuitry of cancer. Nature Reviews, v. 2, p. 231-41, 2001.

HANAHAN, D.; WEINBERG, R. A. The hallmarks of cancer. Cell, v. 100, p. 57-70, 2000.

HARAGUCHI, M.; MIMAKI, Y.; MOTIDOME, Y.; MORITA, H.; TAKEYA, K.; ITOKAWA, H.; YOKOSUKA, A.; SASHIDA, Y. Steroidal saponin from the leaves of Cestrum sendtenerianum. Phytochemistry, v. 55, p. 715-720, 2000.

HARVEIT, F. Sex differences in the intraperitoneal growth of Ehjrlich ascites carcinoma. Acta Pathol et Microbial Scandinav, v. 58, p. 25-32, 1963. 
HARTVEIT, F. The immediate cause of death in mice with Ehrlich's ascites carcinoma. Acta pathologica et microbiologica scandinavica, n.65, p. 359-365, 1965.

HASUI, M.; HIRABAYASHI, Y.; KOBAYASHI, Y. Simultaneous measurement by flow cytometry of phagocytosis and hydrogen peroxide production of neutrophils in whole blood. Journal of Immunological Methods, v. 117, n. 1, p, 53-58, 1989.

HIRIBAYASHI, Y.; TANIUCHI, S.; KOBAYASHI, Y. A quantitative assay of oxidative metabolism by neutrophils in whole blood using flow cytometry. Journal of Immunological Methods, v. 82, p. 253-259, 1985.

HSU, S. M.; RAINE, L.; FANGER, H. Use of Avidin-Biotin-Peroxidase Complex (ABC) in immunoperoxidase techniques: a comparision between $A B C$ and Unlabeled antibody (PAP) procedure. The Journal of Histoquemistry and Cytochemistry, v. 29, n. 4, p. 577-580, 1981.

IYER, L.; RATAIN, M. J. Pharmacogenetics and cancer chemotherapy. European Journal of Cancer, v.34, p. 1493-1499, 1998.

KATO, S.; HOSHIKAWA-FUJIMURA, A. Y.; MARTIN, R. C. T.; SAKAHARA, S. N.; BRUNETO, F. A.; TOLEDO, S. P. A. Ação da Pfaffia paniculata (Martius) Kuntze em células de fibroblasto normal e feocromocitoma. In: REUNIÃO ANUAL DA FEDERAÇÃO DE BIOLOGIA EXPERIMENTAL, 8.,1993, Caxambu. Resumos... Caxambu: FesBE, 1993. p. 283.

KLEIN, G.; KLEIN, E. The transformation of a solid transplantable mouse carcinoma into an "ascites tumor". Cancer Research, v. 11, p. 466-469, 1951.

KOOPER, L.; LAPIS, K. What's new in macrophage-tumor cell interaction? Pathology, Research and Practice v. 179, p. 652-655, 1985.

LALA, P.K. Dynamics of leuckocyte migration into the mouse ascites tumor. Cell Tissue Kinet, v. 7, p. 293-304, 1974.

LEROI, A. M.; KOUFOPANOU, V.; BURT, A. Cancer selection. Nature Reviews, v. 3, p. 226-231, 2003. 
LEVIN, S.; BUCCI, T.; COHEN, S. M.; FIX, A. S.; HARDISTY, J. F.; LEGRAND, E. K.; MARONPOT, R. R.; TRUMP, B. F. The nomenclature of cell death: recommendations of an ad hoc committee of the society of toxicologic pathologists. Toxicologic Pathology, v. 27, n.4, p. 484-490, 1999.

LOEWENTHAL , H.; JAHN, G. Ubertragungsversuch mit carcinomatoser Mauseascitesflussigkeit und ihr verhalten gegen physikalische und chemische Einwirkungen. K. Krebsforrsch, v. 37, p. 439-447, 1932.

MACIEL, M. A. M.; PINTO, A.C.; VEIGA JR., V.F. Plantas medicinais: a necessidade de estudos multidisciplinares. Química Nova, v. 25, n. 3, p. 429-432, 2002.

MALUMBRES, M.; BARBACID, M. To cycle or not to cycle: a critical decision in cancer. Nature Reviews, v.1, p. 222-231, 2001.

MATSUZAKI, P.; AKISUE, G.; OLORIS, S. C. S.; GÓRNIAK, S.; DAGLI, M. L. Z. Effect of Pfaffia paniculata (Brazilian ginseng) on the Ehrlich tumor in its ascitic form. Life Sciences, v.74, p.573-579, 2003.

MAYER, K. D. The pathogenicity of the Ehrlich ascites tumour. British Journal of Experimental Pathology, v. 47, p. 537-544, 1966.

MAZZANTI, G.; BRAGHIROLI, L. Analgesic antiinflammatory action of Pfaffia paniculata (Martius) Kuntze. Phytotherapy Research, v. 8, p. 413-416, 1994

MICHOR, F.; IWASA, Y.; NOWAK, M. A. Dynamics of cancer progression. Nature Reviews., v.4, p. 197-205, 2004.

MOSMANN, T. Rapid colorimetric assay for cellular growth and survival: application to proliferation and citotoxicity assays. Journal of Immunological Methods, v 65, p. 55-63, 1983.

NAKAI, S.; TAKAGI, N.; MIICHI, H.; HAYASHI, S.; NISHIMOTO, N.; TAKEMOTO, T.; $\mathrm{KIZU}, \mathrm{H}$. Pfaffosides and nortriterpenoid saponins from Pfaffia paniculata.

Phytochemistry, v. 23, n. 8, p. 1703-1705, 1984. 
NISHIMOTO, N.; NAKAI, S.; TAKAGI, N.; HAYASHI, S.; TAKEMOTO, T.; ODASHIMA, S.; KIZU, H.; WADA, Y. Pfaffosides and nortriterpenoid saponins from Pfaffia paniculata.

Phytochemistry, v. 23, n. 1, p. 139-142, 1984.

OKADA, H.; MAK, T. W. Pathways of apoptoti and non-apoptotic death in tumor cells.

Nature Reviews, v. 4, p. 592-603, 2004.

OLIVEIRA, F. Pfaffia paniculata (Martius) Kuntze - O ginseng brasileiro. Revista Brasileira de Farmacognosia, v. 1, p. 86-92, 1986.

OLIVEIRA, F.; AKISSUE, G.; AKISSUE, M.K. Contribuição para o estudo farmacognóstico do " ginseng brasileiro" Pfaffia paniculata (Martius) Kuntze. Anais de Farmácia e Química, São Paulo, v. 20, p. 261-77, 1980.

OLORIS, S. C. S; DAGLI, M. L. Z.; GUERRA, J. L. Effect of $\beta$-carotene on the development of the solid Ehrlich tumor in mice. Life Sciences, v. 71, n. 6, p. 717-724, 2002.

POLVERINI, P. J.; COTRAN, R. S.; GIMBRONE, M. A.; UNANUE, E. R. Activated macrophages induce vascular proliferation. Nature. v. 269, p.804-806, 1977.

RANGARAJAN, A. ; WEINBERG, R. A. Comparative biology of mouse versus human cells: modelling human cancer in mice. Nature Reviews, v.3, p. 952-959, 2003.

RENAN, M. J. How many mutations are required for tumorigenesis? Implications from human cancer data. Molecular Carcinogenesis, v. 7, p. 139-146, 1993.

SCHWARTZ, A. G.; MOORE, C. J. Inverse correlation between species life span and capacity of cultured fibroblasts to bind 7,12-dimethylbenz(a)anthracene to DNA.

Experimental Cell Research. v.109, p. 118-150, 1977.

SEZZI, M. L.; BELELLI, L.; NISTA, A. Peritoneal macrophages and neoplastic cells. Oncology, v.26, p. 529-539, 1972.

SILVA, T. C.; SILVA, A. P.; AKISUE, G.; RASPANTINI, P. C.; MATSUZAKI, P.; NAGAMINE, M. K.; AVANZO, J. L.; FUKUMASU, H.; HARAGUCHI, M.; GÓRNIAK, S. L.; DAGLI, M. L. Z. Inhibitory effects of Pfaffia paniculata (Brazilian ginseng) on 
preneoplastic and neoplastic lesions in a mouse hepatocarcinogenesis model. Cancer letters, 2004 (in press).

SIGIURA, K. Tumor transplantation. In: WILLIAN, I.G. Methods of animal experimentation. London: Academic Press, 1965. v. 2. p. 171-222.

SIMÕES, C. M. O.; SCHENKEL, E. P.; GOSMANN, G.; DE MELLO, J. C. P.; MENTZ, L. A; PETROVICK, P. R. Farmacognosia: da planta ao medicamento. 4. ed. Porto Alegre: Editora da UFSC/UFRGS, 2002. 833 p.

SPECTOR, D. L.; GOLDMAN, R. D.; LEINWAND, L. A. Apoptosis assays. In Cells, a laboratory manual culture and biochemical analysis of cells. Ed. Cold Spring, 1988, v. 1 , chapter 15, p. [24].

TAKEMOTO, T.; NISHIMOTO, N.; NAKAI, S.; TAKAGI, N.; HAYASHI, S.; ODASHIMA, S.; WADA, Y. Pfaffic acid, a novel nortriterpene from Pfaffia paniculata Kuntze. Tetrahedron letters, v. 24, n. 10, p.1057-1060, 1983.

TANIGUCHI, S. F.; BERSANI-AMADO, C.; SUDO, L. S.; ASSEF, S. M. C.; OGA, S. Effect of Pfaffia iresinoides on the experimental inflammatory process in rats. Phytotherapy research, v. 8, n.11, p. 568-571, 1997.

UNDERWOOD, J. C. E. Lymphoreticular infiltration in humans tumor: prognostic and biological implications - a review. British Journal of Cancer, v. 30, p. 538-548, 1974.

VIDAL, M. R. R.; VIDAL, W. N. Flórula de Viçosa. I. Chenopodiaceae e Amaranthaceae. Revista Ceres, n. 14, p. 46-79, 1967.

VINCENT, P. C.; NICHOLLS, A. Comparision of the growth of the Ehrlich ascites tumor in male and female mice. Cancer Research, v. 27, p. 1058-1065, 1967.

VORBRODT, A.; GRABSKA, A.; KRZYZOWSKA-GRUCA, S.; GRUCA, S. The formation of contacts between macrophages and neoplastic cells. Folia histochemica et cytochemica, v. 11, n. 3-4, p. 185-190, 1973. 
WATANABE, T.; WATANABE, M.; WATANABE, Y.; HOTTA, C. Effects of oral administration of Pfaffia paniculata on incidence of spontaneous Leukemia in AKR/J nice. Cancer Detection and Prevention, v. 24, n. 2, p. 173-178, 2000. 